\title{
A Study of Critical Thinking Training in the Army Contracting Workforce
}

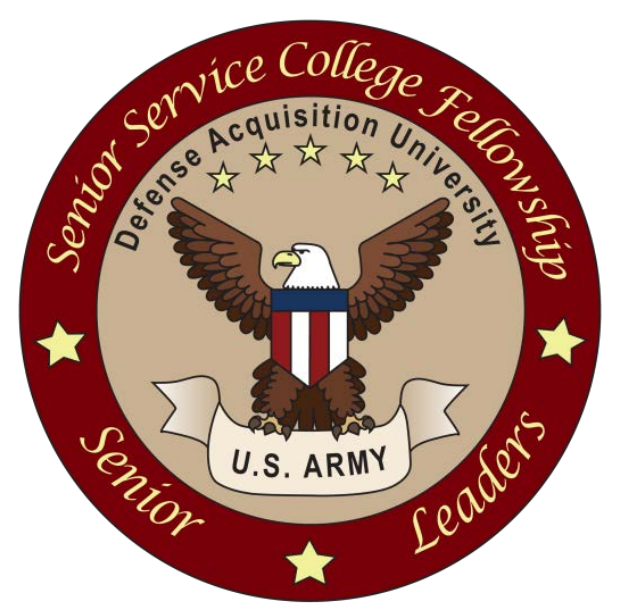

Cheryl L. Jones

Defense Acquisition University

Senior Service College Fellowship 2015-2016

Huntsville, Alabama

23 March 2016

This research paper is presented to the Defense Acquisition University for partial fulfillment of the academic requirements for the Army’s Senior Service College Fellowship (SSCF) under the direction of SSCF Director Mr. John Daniels and Research Advisor Mrs. Diane Whitmore.

Distribution Statement A, Approved for Public Release, 7 April 2016, U.S. Army Contracting Command 


\section{Approval Page}

Title: A Study of Critical Thinking Training in the Army Contracting Workforce

Author: Cheryl L. Jones

Organization: DAU-South, Senior Service College Fellowship (SSCF)

Date of Paper: 18 March 2016

Informed Consent Forms Completed and On-file: 18 March 2016

Research Advisor [Diane Whitmore] Approval Date: 18 March 2016

SSCF Director [John Daniels] Approval Date: 23 March 2016

OPSEC Approval Date: 7 April 2016

Approval for Public Release Date: 7 April 2016

Date submitted for Journal Publication: 


\section{Acknowledgements}

I would like to acknowledge the efforts of the U.S. Army Contracting Command's contracting professionals, staff, and leadership for their assistance and support in this research project. I would like to thank the Defense Acquisition University Contracting Management faculty members, the Defense Acquisition University South Region leadership and staff, and my research advisor for their support and guidance, which was instrumental in completing this research paper. 


\begin{abstract}
With the simultaneous challenges of an increasingly fiscally constrained environment and the continuing need for advancements in our Warfighting capabilities, the imperative to do more with less was manifested in the Department of Defense’s (DoD’s) Better Buying Power (BBP) initiatives. The BBP goals of restoring affordability, increasing efficiencies, delivering better value, and achieving technical excellence and innovation in DoD acquisitions all require the Army's acquisition workforce to think critically about programs and to craft sound acquisition decisions to successfully implement the BBP initiatives. The research gathered the perspectives of the Army contracting workforce and Defense Acquisition University (DAU) contracting faculty members regarding the readiness of the Army contracting workforce in the area of critical thinking skills. The research examines the question, "Does the current required Defense Acquisition Workforce Improvement Act contracting training address the training of critical thinking skills sufficient to implement Better Buying Power initiatives?” The study identifies methods the Army contracting workforce uses to obtain or improve critical thinking skills and the effectiveness of those methods. The research also examines the DAU mandatory contracting curriculum to determine if the current curriculum was effective in teaching critical thinking skills and if improvements are warranted. The objective of this research is to provide Army contracting and DAU leadership with additional information and recommendations to assist in the development of improved critical thinking skills within the Army contracting workforce.
\end{abstract}




\section{Table of Contents}

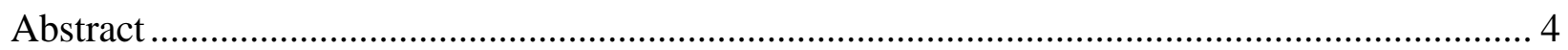

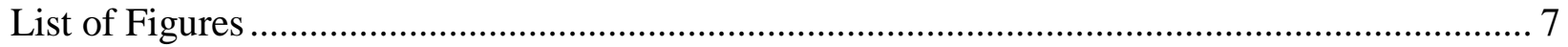

Chapter 1 - A Study of Critical Thinking Training in the Army Contracting Workforce ............. 9

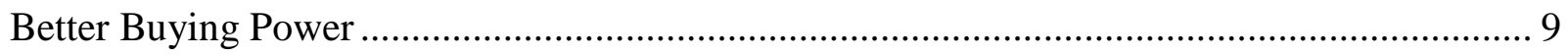

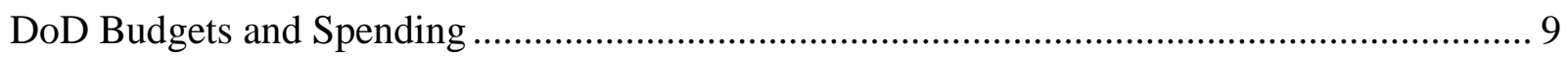

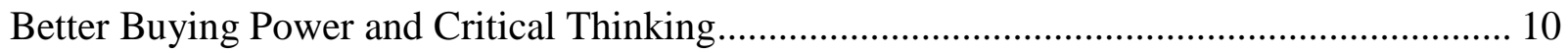

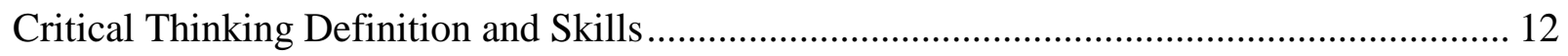

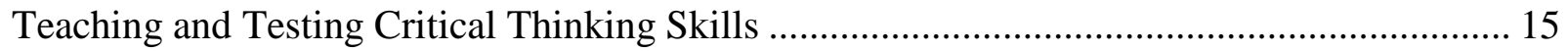

Certification Standards for the Acquisition Workforce ................................................... 17

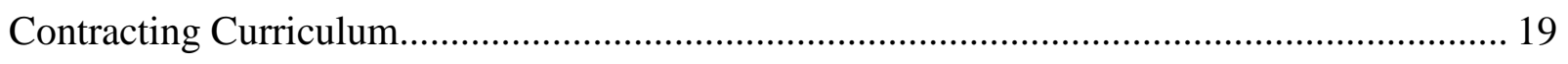

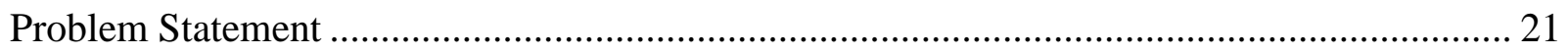

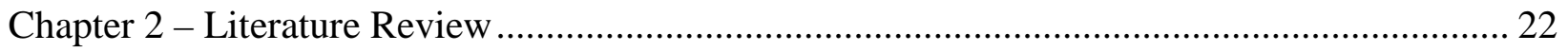

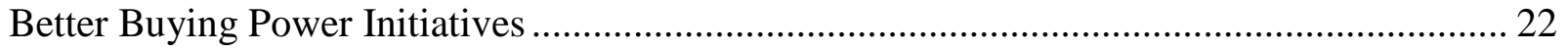

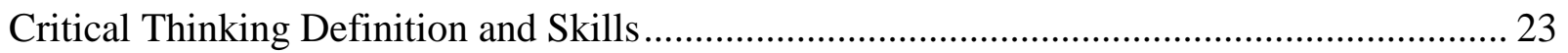

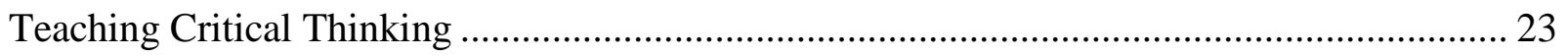

Certification Standards and Contracting Curriculum..................................................... 24

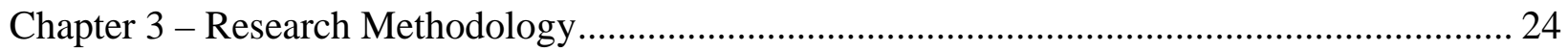

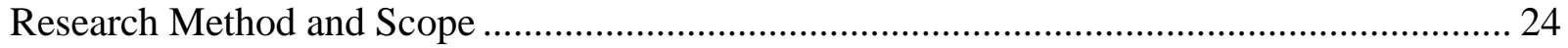

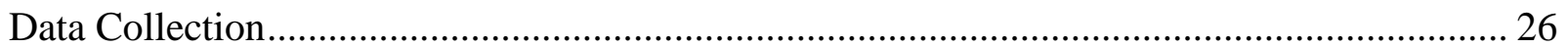

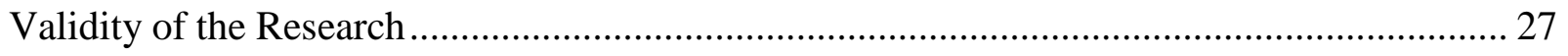

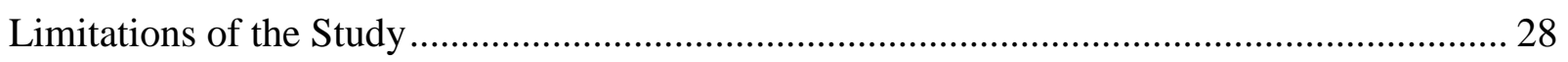

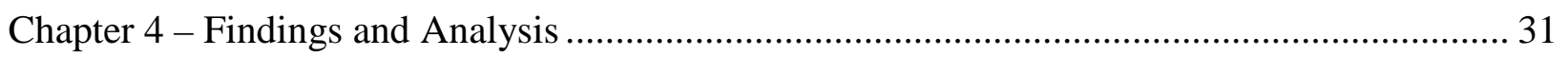

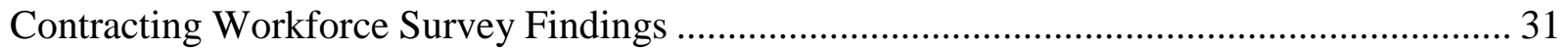

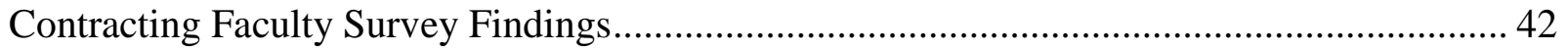

Contracting Curriculum Analysis............................................................................... 56

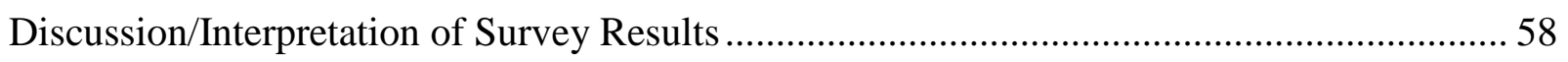

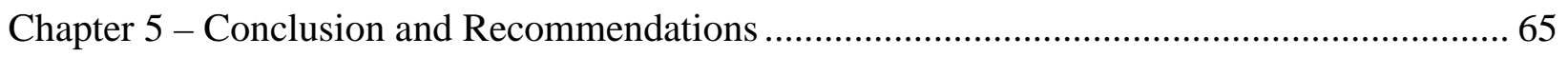

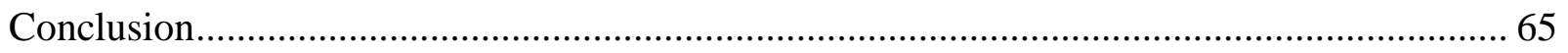

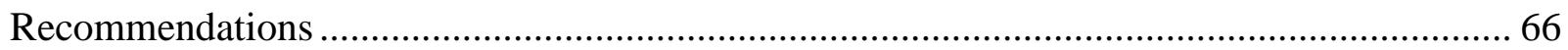

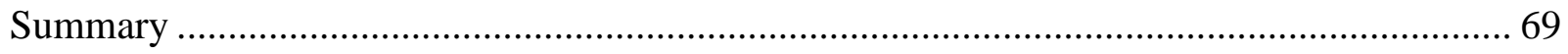




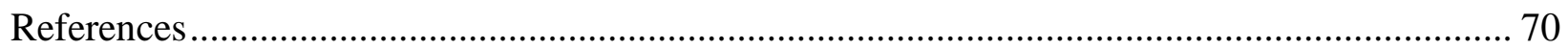

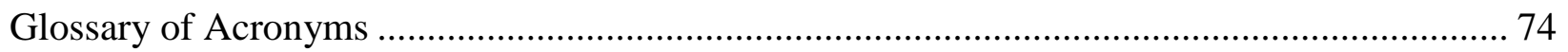

Appendix A - Better Buying Power Summary........................................................................ 75

Appendix B - Contracting Certification Curriculum.................................................................... 77

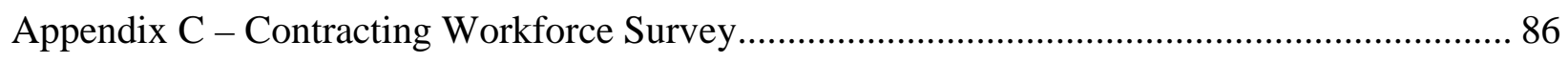

Appendix D - Contracting Faculty Survey ................................................................................ 94

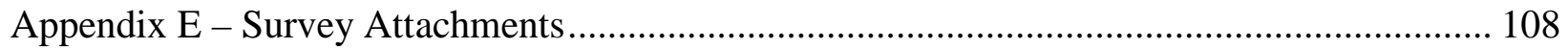

Appendix F - Survey Demographics ..................................................................................... 110 


\section{List of Figures}

Figure 1. Fiscal year 2015 obligations and contract actions............................................. 10

Figure 2. Core critical thinking skills. ........................................................................... 13

Figure 3. Approaches to life that characterize the ideal critical thinker. ................................. 14

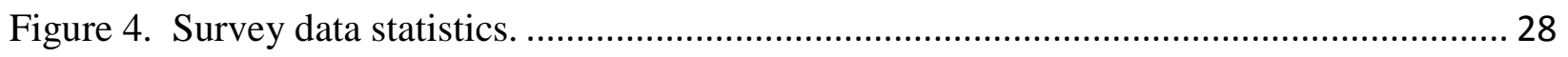

Figure 5. Experience with training methods (workforce) ................................................. 32

Figure 6. Effectiveness of training methods (workforce) .................................................... 33

Figure 7. Methods to increase training effectiveness (workforce). ........................................ 34

Figure 8. Reasons for not taking critical thinking training (workforce)................................ 35

Figure 9. Adequacy of training opportunities (workforce) ................................................. 36

Figure 10. Most effective training methods (workforce)..................................................... 36

Figure 11. Average importance of critical thinking skills (workforce). .................................. 38

Figure 12. Skills assessment (workforce) ........................................................................... 38

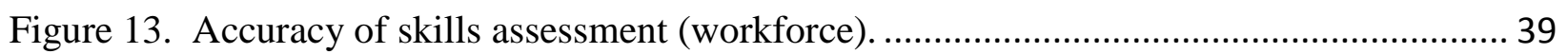

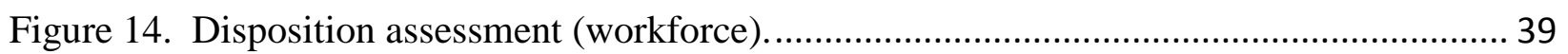

Figure 15. Accuracy of disposition assessment (workforce). ................................................ 40

Figure 16. Disposition assessment methods (workforce)................................................ 40

Figure 17. Involvement in BBP contracting issues (workforce) ......................................... 41

Figure 18. Frequency of skills used for BBP issues (workforce). ........................................ 42

Figure 19. Recent courses with critical thinking (faculty)................................................ 44

Figure 20. Level I courses - critical thinking curriculum effectiveness (faculty).................... 45

Figure 21. Level II courses - critical thinking curriculum effectiveness (faculty).................... 45

Figure 22. Level III courses - critical thinking curriculum effectiveness (faculty).................. 46

Figure 23. Overall average effectiveness of Level I, II \& III courses (faculty). ....................... 46

Figure 24. Extent critical thinking skills exhibited in Level I, II, \& III classes (faculty)........... 47

Figure 25. Average effectiveness of critical thinking skills training methods (faculty)............. 49

Figure 26. Confidence in workforce ability to use critical thinking (faculty). ........................ 50

Figure 27. Critical thinking areas for improvement (faculty)............................................. 51

Figure 28. Critical thinking related course revisions (faculty)......................................... 52

Figure 29. Critical thinking improvements related to course revisions (faculty). ..................... 52

Figure 30. Faculty suggestions for critical thinking training improvements (faculty)............... 54

Figure 31. Case-based scenario \& simulations course addition (faculty)............................... 54

Figure 32. Comments on case-based scenario course (faculty).......................................... 55

Figure 33. Critical thinking in CON curriculum.......................................................... 57

Figure 34. Comparison of training methods effectiveness rankings.................................... 59

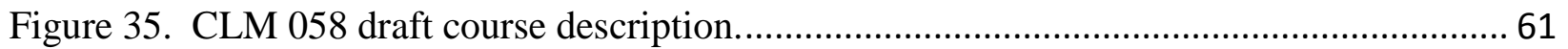

Figure 36. Respondent status (workforce) ................................................................. 110

Figure 37. Respondent rank or paygrade (workforce) ..................................................... 111

Figure 38. Generational breakdown (workforce)............................................................ 111 


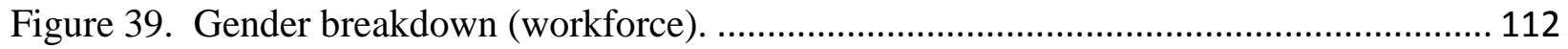

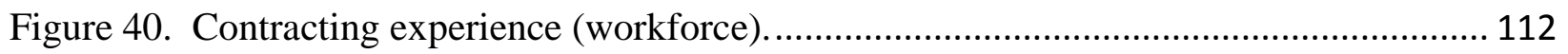

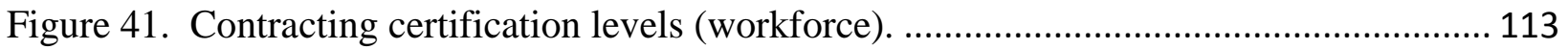

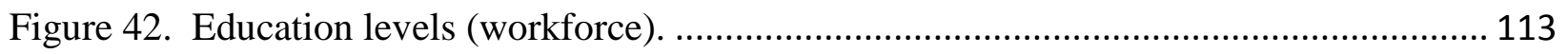

Figure 43. ACC command representation (workforce). ........................................................ 114

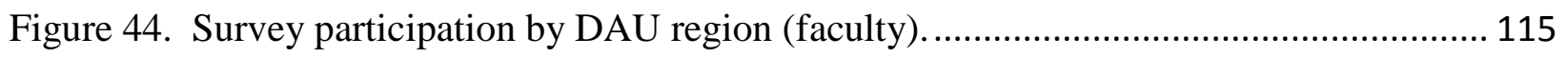

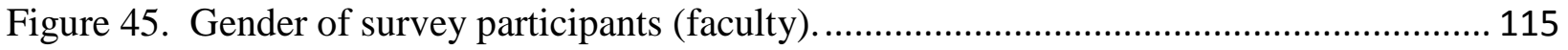

Figure 46. Teaching experience and how gained (faculty)....................................................... 116

Figure 47. Professional experience and how gained (faculty).................................................. 116 


\section{Chapter 1 - A Study of Critical Thinking Training in the Army Contracting Workforce}

The quotation “Gentlemen, We Have Run Out Of Money; Now We Have to Think.” is widely attributed to Winston Churchill (Churchill, n.d.), but the idea is pertinent to today’s Department of Defense (DoD) acquisition activities. With the simultaneous challenges of a fiscally constrained environment and the ever continuing need for advancements in our warfighting capabilities, the imperative for DoD to do more with less was manifested in the DoD’s Better Buying Power (BBP) initiatives (Defense Acquisition University, 2016).

\section{Better Buying Power}

According to the Defense Acquisition University (DAU) website discussion of BBP, BBP is “the implementation of best practices to strengthen the Department of Defense's buying power, improve industry productivity, and provide an affordable, value-added military capability to the Warfighter” (2016, Better Buying Power section). BBP is a series of memos issued by the Under Secretary of Defense for Acquisition, Technology, and Logistics (USD(AT\&L)) and has seven focus areas: achieving affordable programs, controlling costs, incentivizing innovation and productivity, eliminating unproductive processes, promoting competition, improving the acquisition of services, and improving the professionalism of the Acquisition Workforce (Defense Acquisition University, 2016). Appendix A provides more information on BBP.

\section{DoD Budgets and Spending}

According to the DoD Fiscal Year (FY) 2016 Budget Request Overview, DoD’s FY 2016 budget is an increase over the FY 2015 budget, but it comes after several years of declining budgets each year starting in FY 2010 (Department of Defense, 2015). The recent trend of declining DoD budgets and the threat of executing the DoD mission under sequestration spending levels adds to DoD’s fiscal uncertainty (Department of Defense, 2015). 
How much does DoD spend? The total enacted FY 2015 DOD budget was \$560.4B (Department of Defense, 2015). Department of the Army (DA) contracting professionals obligate large sums of money annually and are responsible for many of the business decisions that shape a large number of contract actions. According to the Federal Procurement Data System-Next Generation reporting system, the DoD, DA, and the U.S. Army Contracting Command (ACC) reported the following amounts to Congress for fiscal year (FY) 2015:

\begin{tabular}{|l|l|l|l|l|}
\hline & Dollars obligated & $\begin{array}{l}\text { Percentage of } \\
\text { DoD } \\
\text { obligations }\end{array}$ & $\begin{array}{l}\text { Number of contract } \\
\text { actions }\end{array}$ & $\begin{array}{l}\text { Percentage of } \\
\text { DoD actions }\end{array}$ \\
\hline DoD & $\$ 273.7$ billion & $100 \%$ & $12,576,818$ & $100 \%$ \\
\hline DA & $\$ 72.6$ billion & Over $26.5 \%$ & 281,284 & Over $2.2 \%$ \\
\hline ACC & $\$ 51.8$ billion & Over $18.9 \%$ & 165,330 & Over $1.3 \%$ \\
\hline
\end{tabular}

Figure 1. Fiscal year 2015 obligations and contract actions (Federal Procurement Data System-Next Generation, 2015).

According to DoD's series of BBP guidance, a professional contracting workforce with advanced critical thinking skills is better equipped to help shape improved business arrangements, resulting in increased efficiency, effectiveness, and innovation within Army acquisition and savings for DoD and the Army (Carter, 2010; Kendall, 2012, 2014).

\section{Better Buying Power and Critical Thinking}

The Honorable Ashton Carter, USD(AT\&L), first introduced the idea of Better Buying Power initiatives to the acquisition workforce in June 2010. Restoring affordability, increasing efficiencies, and delivering better value to the warfighter and the taxpayer for DoD goods and services were the primary focus areas of the new initiative (Carter, 2010). Under Secretary Carter introduced the importance of critical thinking by stating that a "process of analysis and dialogue is necessary to make sure our actions are effective and soundly based” (Carter, 2010, para. 7). This philosophy continued with his successor. 
For DoD’s BBP initiatives to be successful, the Honorable Frank Kendall, USD(AT\&L), discussed the need for a skilled DoD acquisition workforce. Kendall's BBP 2.0 introduced a new focus area: improving the professionalism of the total acquisition workforce, the most important factor of the Defense Acquisition System (2012). There was a continued emphasis on the importance of sound business decisions being made by the acquisition workforce (Kendall, 2012). In his testimony on the acquisition workforce before the House Committee on Armed Services (HASC) on July 10, 2014 Kendall stated:

A primary goal of Better Buying Power 2.0 is to help the workforce to think critically about their programs and focus on sound decisions tailored to the problem at hand. It's about understanding through education, training, and experience, what works, what doesn’t, and most importantly the why and how to best implement a specific decision. ... We won’t get acquisition “right” unless these decisions are sound. (Testimony - Kendall, 2014, p. 3)

Although Kendall’s 2015 BBP 3.0 directive placed a strong emphasis on achieving technical excellence and innovation, it maintained a focus on improving the acquisition workforce. For example, Kendall called for stronger experience requirements to improve professionalism for all acquisition specialties and higher standards for key leadership positions (Kendall, 2015). BBP 3.0 Implementation Guidance indicated that career certification should have a measurable demonstration of experience for positions-stressing quality over quantity of experience (Kendall, 2015). Skills in critical thinking may be a component in improving professionalism in the acquisition workforce. 


\section{Critical Thinking Definition and Skills}

There are almost as many definitions of critical thinking as there are researchers and experts on the subject. A panel of 46 critical thinking experts (including Dr. Peter Facione, critical thinking expert and Delphi Report Principle Investigator), participated in an extensive research effort in 1988 known as the Delphi panel to come to consensus on the topic of critical thinking (Facione, 1990). Facione provided the panel's consensus statement on what critical thinking is and the cognitive skills and dispositions required of the ideal critical thinker:

We understand critical thinking to be purposeful, self-regulatory judgement which results in interpretation, analysis, evaluation, and inference, as well as explanation of the evidential, conceptual, methodological, criteriological, or contextual considerations upon which that judgement is based. . . . The ideal critical thinker is habitually inquisitive, well-informed, trustful of reason, open-minded, flexible, fair-minded in evaluation, honest in facing personal biases, prudent in making judgements, willing to reconsider, clear about issues, orderly in complex matters, diligent in seeking relevant information, reasonable in the selection of criteria, focused on inquiry, and persistent in seeking results which are as precise as the subject and the circumstances of inquiry permit.... (Facione, 1990, p. 2) ${ }^{1}$

Facione further explained in a 2015 update to the Delphi findings: "In the absence of critical thinking, one might simply follow the demands of authority, act without a full awareness

$1 \quad$ The findings of expert consensus pertaining to critical thinking cited and referenced in this research paper are published in various essays, reports, summaries, and manuals available from Insight Assessment at www.insightassessment.com. Permission to use copyrighted material has been obtained from Insight Assessment by the author. 
of the situation, thoughtlessly do what has been done before, or do nothing when action is needed” (2015a, p. 4).

In the Delphi study, the experts found that a good critical thinker had both certain cognitive skills and the disposition to use those skills - critical thinkers are both willing and able to think critically (Facione, 1990). The research will use discussion of the cognitive skills the experts deemed to be “core critical thinking skills” (Facione, 2015b, pp. 9 - 10) as the basis for

\begin{tabular}{|c|c|c|}
\hline \multicolumn{3}{|c|}{ Core Critical Thinking Skills } \\
\hline SKILL & Experts' Consensus Description & Subskill \\
\hline Interpretation & $\begin{array}{l}\text { "To comprehend and express the meaning or significance of a wide } \\
\text { variety of experiences, situations, data, events, judgments, } \\
\text { conventions, beliefs, rules, procedures, or criteria" }\end{array}$ & $\begin{array}{l}\text { Categorize } \\
\text { Decode significance } \\
\text { Clarify meaning }\end{array}$ \\
\hline Analysis & $\begin{array}{l}\text { "To identify the intended and actual inferential relationships among } \\
\text { statements, questions, concepts, descriptions, or other forms of } \\
\text { representation intended to express belief, judgment, experiences, } \\
\text { reasons, information, or opinions" }\end{array}$ & $\begin{array}{l}\text { Examine ideas } \\
\text { Identify arguments } \\
\text { Identify reasons and claims }\end{array}$ \\
\hline Inference & $\begin{array}{l}\text { "To identify and secure elements needed to draw reasonable conclusions; } \\
\text { to form conjectures and hypotheses; to consider relevant information and } \\
\text { to reduce the consequences flowing from data, statements, principles, } \\
\text { evidence, judgments, beliefs, opinions, concepts, descriptions, questions, } \\
\text { or other forms of representation" }\end{array}$ & $\begin{array}{l}\text { Query evidence } \\
\text { Conjecture alternatives } \\
\text { Draw logically valid or justified } \\
\quad \text { conclusions }\end{array}$ \\
\hline Evaluation & $\begin{array}{l}\text { "To assess the credibility of statements or other representations that are } \\
\text { accounts or descriptions of a person's perception, experience, situation, } \\
\text { judgment, belief, or opinion; and to assess the logical strength of the actual } \\
\text { or intended inferential relationships among statements, descriptions, } \\
\text { questions, or other forms of representation" }\end{array}$ & $\begin{array}{l}\text { Assess credibility of claims } \\
\text { Assess quality of arguments } \\
\text { that were made using } \\
\text { inductive or deductive } \\
\text { reasoning }\end{array}$ \\
\hline Explanation & $\begin{array}{l}\text { 'To state and to justify that reasoning in terms of the evidential, } \\
\text { conceptual, methodological, criteriological, and contextual considerations } \\
\text { upon which one's results were based; and to present one's reasoning in } \\
\text { the form of cogent arguments" }\end{array}$ & $\begin{array}{l}\text { State results } \\
\text { Justify procedures } \\
\text { Present arguments }\end{array}$ \\
\hline Self-Regulation & $\begin{array}{l}\text { "Self-consciously to monitor one's cognitive activities, the elements used } \\
\text { in those activities, and the results educed, particularly by applying skills in } \\
\text { analysis, and evaluation to one's own inferential judgments with a view } \\
\text { toward questioning, confirming, validating, or correcting either one's } \\
\text { reasoning or one's results" }\end{array}$ & $\begin{array}{l}\text { Self-monitor } \\
\text { Self-correct }\end{array}$ \\
\hline
\end{tabular}

Figure 2. Core critical thinking skills (Facione, 2015b, pp. 9 -10). 
survey questions on critical thinking skills. Facione, in his essay "Critical Thinking: What It is and Why It Counts”, provides descriptions of those cognitive skills as listed in Figure 2.

Facione (2015b, p. 11) discusses the characteristics of strong critical thinkers in terms of how they approach life in general (as illustrated in Figure 3) and how they are disposed towards using their critical thinking skills:

Strong critical thinkers can also be described in terms of how they approach specific issues, questions, or problems. The experts said you would find these sorts of characteristics:

- clarity in stating the question or concern,

- orderliness in working with complexity,

- diligence in seeking relevant information,

- reasonableness in selecting and applying criteria,

- care in focusing attention on the concern at hand,

- persistence though difficulties are encountered,

- precision to the degree permitted by the subject and the circumstances. (Facione, 2015b, p. 11)

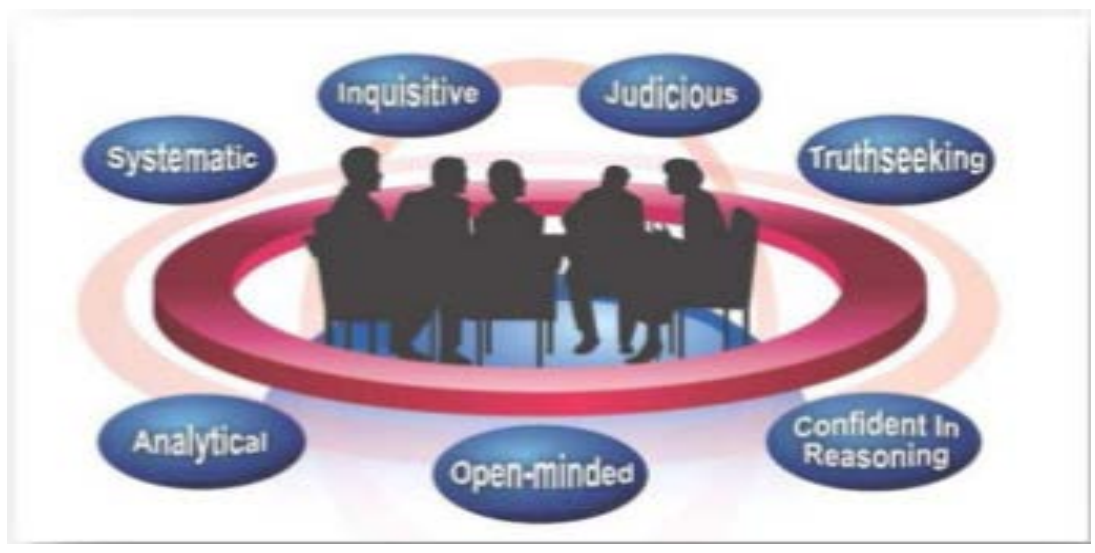

Figure 3. Approaches to life that characterize the ideal critical thinker (Facione, 2015b, p. 12). 
Can the core critical thinking skills be taught to develop strong critical thinkers? The next section examines experts’ ideas about how to teach critical thinking.

\section{Teaching and Testing Critical Thinking Skills}

David Garvin, Harvard Business professor, indicates that the Harvard Business School began using the case method to teach students how to evaluate business situations and make appropriate decisions as early as 1919 (Garvin, 2003). Garvin (2003) asserts that cases include irrelevant and incomplete information, forcing students to use critical thinking skills. The case method teaches students to evaluate ambiguous situations, make difficult choices, develop analytical and persuasive skills, and think a different way to resolve problems (Garvin, 2003). Mauffette-Leenders, Erskine, and Leenders (2014) in Learning with Cases, teach the case method as an extension of the Harvard business case method. Mauffette-Leenders, Erskine, and Leenders (2014) cite analytical skills as one of the skills developed by students using the case method.

The case method enables you to develop qualitative and quantitative frameworks to analyze business situations, including problem identifications skills; data handling skills; and critical thinking skills. You are forced to reason clearly and logically in sifting through the data available. (Mauffette-Leenders, Erskine, and Leenders, 2014, p. 5) Mauffette-Leenders, Erskine, and Leenders (2014) assert that critical thinking skills can be taught using the case method.

The effective manager learns continuously and allocates time and effort appropriately. Critical thinking skills, not the simple pursuit of management fads, make the difference between successful and less successful managers. Managers need to assess every situation individually, identify the problems, issues, challenges, opportunities or 
decisions involved and define appropriate decision criteria and alternatives. The basics of sound decision making and problem solving require continuous attention, practice and persistence. Case solving tasks can be seen as a process and managed as a process. It is a learnable and improvable process. (Mauffette-Leenders, Erskine, and Leenders, 2014, pp. 119 - 120)

Daniel Willingham, professor of cognitive psychology at the University of Virginia, has some additional thoughts on teaching critical thinking (Willingham, 2007). Willingham states that "critical thinking is not a set of skills that can be deployed at any time, in any context. .. . [I]t is very much dependent on domain knowledge and practice” (2007, p. 10). Willingham (2007) asserts that students must have knowledge of a topic if they are to critically think about it. According to Willingham (2007), when a student encounters a problem, that problem is interpreted based on the student's prior knowledge of the topic. Deep thought requires deep knowledge of the topic (Willingham, 2007, p. 11).

Alison King, psychology professor at California State University, San Marcos, uses an alternate method altogether to teach critical thinking skills - reciprocal peer questioning (King, 1995). According to King (1995), this method requires students to develop their own questions using a set of generic questions to promote effective critical thinking in the classroom. King asserts reciprocal peer questioning is effective because the process of generating the question uses critical thinking skills (1995). When students use peer questioning, they find that their “own perceptions, facts, assumptions, values, and general understandings of the material differ... from those of others. When confronted with these conceptual discrepancies, we want to reconcile the conflicts” (King, 1995, p. 16). This requires students to explain and defend their 
views, which teaches students to think (King, 1995). Federal acquisition leaders also had ideas about how to improve critical thinking in the acquisition workforce.

The Professional Services Council and Grant Thornton (2015) recently conducted an Acquisition Policy Survey by interviewing more than 50 Federal Government senior acquisition executives. Survey respondents indicated that a skill gap in business acumen skills existed in the current acquisition workforce and there was a need to improve the current training and education system to increase functional experience and improve critical thinking in Federal acquisition professionals (Professional Services Council \& Grant Thornton, 2015). The survey cited more on-the-job training and experience and more real-life case studies and simulations of real-life situations as being desirable additions to acquisition workforce training (Professional Services Council \& Grant Thornton, 2015).

There are multiple testing venues available commercially from organizations specializing in the evaluation of critical thinking. For example, Insight Assessment (2016) offers assessments to measure critical skills and to measure an individual's disposition to use their critical thinking skills. Insight Assessment (2016) markets specialized critical thinking tests for a variety of purposes such as screening applicants prior to employment, entry into executive programs, and college admissions (Insight Assessment, 2016). Assessments of critical thinking skills, however, are not required for certification of the contracting workforce (Defense Acquisition University, 2015a).

\section{Certification Standards for the Acquisition Workforce}

Public Law 101-510, Title XII - Defense Acquisition Workforce, more commonly known as the Defense Acquisition Workforce Improvement Act (DAWIA), became law on 5 November 1990. DAWIA (1990) granted the Secretary of Defense the ability to effectively 
manage the DoD Acquisition Workforce. DAWIA established Directors of Acquisition Career Management (DACMs) for each military department and directed the Secretary of Defense to designate required acquisition positions for the acquisition career fields (Defense Acquisition Workforce Improvement Act, 1990, § 1721). DAWIA also directed the Secretary of Defense to “establish and maintain a defense acquisition university [DAU] structure to provide for ... the professional educational development and training of the acquisition workforce” (Defense Acquisition Workforce Improvement Act, 1990, § 1746).

Evelyn Layton (2007) authored a history of DAU covering the years 1992 - 2003. Layton (2007) discusses DAWIA's direction that comprehensive career programs be established for military and civilian acquisition workforce members and that these programs were to include direction on accession, education, training, experience, promotion, and retention of the acquisition workforce. According to Layton (2007), certification requirements of progressive training, formal education, and experience were key elements of the career programs. Additionally, an elite acquisition corps was established for military and civilian workforce members who were selected for the most senior acquisition positions (Layton, 2007).

DoD Directive 5000.52, Defense Acquisition Education, Training, and Career Development Program, and its accompanying DoD Manual 5000.52-M, Career Development Program for Acquisition Personnel, were issued to implement DAWIA (Layton, 2007). DoD Manual 5000.52-M defines the experience, education, and training requirements for certification at Levels I, II, and III of the Contracting career path, as well as the other acquisition workforce career paths (Department of Defense, 1995). 


\section{Contracting Curriculum}

According to Layton (2007), most government courses were lecture based before DAWIA. After DAWIA, DAU began to use more interactive exercises, simulations, case studies, and computer-based learning as the basis for its courses (Layton, 2007).

Layton (2007) explains that in 1992, the Office of Federal Procurement Policy required DAU curricula developers to establish competency based training. “Competency-based training requires that learners master the knowledge, skills, and abilities that emphasize application and use of what has been learned. It clearly defines what students are expected to know and be able to demonstrate in applying that knowledge” (Layton, 2007, p. 42). Layton (2007) discusses the DoD 5000.52-M establishing three levels of certification and mandatory courses as being required for each level. Layton (2007) indicates that Level I courses provide for comprehension of fundamental knowledge; Level II courses build on that fundamental knowledge and allow for more practical application and analysis of material in small groups; and Level III courses call for the students to synthesize knowledge and apply critical thinking skills, using practical situations to make sound judgments and develop creative solutions (Layton, 2007).

The Federal Acquisition Regulation (FAR) and its supplements are the basis for Federal and agency contracting policies. According to Layton (2007), the 1994 Federal Acquisition Streamlining Act reforms resulted in major changes to the FAR. To address the FAR changes, DAU contracting courses began to emphasize creativity, sound decision-making, and more complex problem solving skills (Layton, 2007, pp. 74-75). Layton states that "between 1994 and 1997, DAU developed 15 courses applying competency-based education principles. ... The courses not only used sound instructional design principles but also learner-centered teaching methods such as case studies, experiential learning, and simulation” (Layton, 2007, p. 77). 
In 2000, DAU published its 2001 Business Plan, Smart Business 20/20. In the plan, DAU included developing critical thinking skills as one of its strategic thrust areas:

We will provide the workforce performance-targeted learning through hands-on, tailored curricula focused on developing practical insights in order to enhance job performance. In addition we must assist the acquisition community in developing critical thinking skills in order to execute smart business decisions. To support and promote critical thinking, faculty will often be required to facilitate performance-targeted learning by assisting learners in synthesizing and evaluating challenging problem-based scenarios. The goal of critical thinking is to produce learners who can evaluate situations and then consistently make the right decisions. (Defense Acquisition University, 2000, p. 15)

In 2001, DAU included critical thinking as “a central theme throughout all DAU courses, especially level III courses. The curriculum will be scenario-based and/or case-based and will depict contemporary and emerging problems students will encounter on the job” (Defense Acquisition University, 2001, p. 3). DAU's stated goal is to ensure the Acquisition, Technology, and Logistics workforce has the right skills to craft smart business transactions (Defense Acquisition University, 2001).

In 2011, Shay Assad, Director of Defense Procurement Acquisition Policy (DPAP), issued a memorandum directing a revision of the contracting curriculum in FY 2012. Assad (2011) discussed a competency assessment of the contracting workforce that indicated skill gaps in several areas identified for improvement in Better Buying Power 1.0 guidance. Changes to the contracting curriculum and certification training were to address those skill gaps (Assad, 2011). 
The current courses for Level I, II, and III certification in the contracting career field are listed in the Certification Standards \& Core Plus Development Guide for Contracting Levels I, II, and III and are mandatory to achieve certification at each level (Defense Acquisition University, 2015a). Appendix B contains the core certification standards and descriptions from the DAU Contracting Level I, II, and III Certification Standards \& Core Plus Development Guides.

\section{Problem Statement}

Better Buying Power initiatives are a means to restore affordability, increase efficiencies, and deliver better value to the American taxpayer in the acquisition of DoD systems and services, while still achieving technical excellence and innovation for the Warfighter (Kendall, 2015). These initiatives require that the DoD Acquisition Workforce apply critical thinking skills to develop and implement sound decisions to achieve these goals (Kendall, 2015).

The purpose of this research is to survey the Army contracting workforce for perspectives on sufficient critical thinking skills to make sound business decisions to help implement Better Buying Power initiatives. This study will identify methods the Army contracting workforce uses to obtain or improve critical thinking skills, impressions of the effectiveness of critical thinking training, and recommendations to improve the effectiveness of the critical thinking training.

The research analyzes DAU contracting professors’ opinions on DAU’s training of critical thinking. This study explores the effectiveness of DAU's critical thinking training within the contracting curriculum, the most effective methods to teach critical thinking skills, and the extent professors are observing critical thinking in the classroom. Faculty recommendations for improving critical thinking training and ideas for future study were solicited as well.

The areas of inquiry discussed in the problem statement will answer the research question, "Does the current required Defense Acquisition Workforce Improvement Act 
contracting training address the training of critical thinking skills sufficient to implement Better Buying Power initiatives?” The objective of this research is to provide Army contracting and DAU leadership with additional information and recommendations on contracting training to assist in the development of improved critical thinking skills within the Army contracting workforce. The literature reviewed in the following section provided the background and context for this research project.

\section{Chapter 2 - Literature Review}

The purpose of the literature review is to provide amplifying information about the background, context, and common definitions for areas involved in this study: DoD Better Buying Power initiatives, critical thinking definition and skills, methods for teaching critical thinking, and certification standards and the corresponding DAU contracting curriculum. DoD BBP policy documents, Army regulations, DAWIA legislation, and academic articles, studies, and books on the topic of critical thinking were reviewed for relevant information.

\section{Better Buying Power Initiatives}

A series of three USD(AT\&L) memorandums addressing Better Buying Power initiatives and Congressional testimony on the acquisition workforce were reviewed:

- $\quad$ BBP 1.0 issued June 2010 by Carter;

- $\quad$ BBP 2.0 issued November 2012 by Kendall;

- Kendall’s Congressional Testimony to HASC in September 2014; and

- $\quad$ BBP 3.0 issued April 2015.

The BBP memos and Congressional testimony emphasized the importance of the acquisition workforce's ability to apply critical thinking skills to develop sound decisions for the successful implementation of the initiatives. Material dated 2010 to 2015 covering the three phases of 
Better Buying Power to date applied to this topic. Appendix A contains additional information on BBP.

\section{Critical Thinking Definition and Skills}

Articles, studies, and books on critical thinking written by critical thinking experts and academics revealed a definition of critical thinking and a list of essential critical thinking skills. Due to the wide range and large variation of the definitions applied to the topic, the common definition used for the research relied on an expert study (known as The Delphi Report) to define critical thinking and identify related skills. The Delphi Report (Facione, 1990) was a consensus report on critical thinking derived from the efforts of 46 widely recognized critical thinking experts. The critical thinking literature review covered material dated 1990, the publication date of the Delphi Report, to 2015.

\section{Teaching Critical Thinking}

The research included a review of various articles and books written by professors who used different methods to teach critical thinking skills. A review of the internet websites of several organizations offering critical thinking assessments, including Insight Assessment, The Critical Thinking Community, and CriticalThinking.Net was conducted. The literature review explored professionals' views on critical thinking teaching methods, described the case method currently used by DAU to teach critical thinking, and determined if critical thinking skills can be tested and measured. The literature review served as the basis for information for the development of several of the contracting workforce and DAU faculty survey questions and some of the recommendations for this research project. Literature for this section of the research was published from 1995 to 2016. 


\section{Certification Standards and Contracting Curriculum}

A review of the Defense Acquisition Workforce Improvement Act, the DoD acquisition career development directive and its implementing guidance (DoD Manual 5000.52-M), a book on the history of DAU, online DAU documentation, and a 2011 DPAP memorandum provided context on the major reasons for contracting curriculum changes throughout DAU's history, as well as information on DAU's emphasis on critical thinking. The current contracting curriculum was reviewed on DAU's website and is the basis for several survey questions and to determine which course descriptions include critical thinking instruction. The literature review covered the period 1990 to 2016, to include DAWIA and current online contracting certification course information. The methodology used for this research and study limitations are discussed in the following section.

\section{Chapter 3 - Research Methodology}

\section{Research Method and Scope}

The research method used for this study was to design two quantitative surveys to answer the question posed by the problem statement: "Does the current required Defense Acquisition Workforce Improvement Act contracting training address the training of critical thinking skills sufficient to implement Better Buying Power initiatives?”

The first survey was designed to obtain information by questioning the workforce's training experiences about the following: the effectiveness of critical thinking training, suggestions for improving effectiveness, the importance of critical thinking in making sound business decisions, if they had ever participated in a critical thinking skills assessment, and the perceived use of critical thinking skills for the contracting functions involved with various Better 
Buying Power initiatives. The workforce survey is located at Appendix C - Contracting Workforce Survey.

The second survey obtained information about the DAU contracting faculty’s experiences with teaching critical thinking (or the use of those skills) in mandatory contracting certification courses at DAU. The questions on this survey asked the faculty to rate the effectiveness of critical thinking instruction in Contracting Level I, II, and III mandatory courses and the extent the faculty observed students using those skills in the classroom. The faculty were asked to rank the effectiveness of various methods for teaching critical thinking skills and to express general impressions of the contracting workforce's ability to use critical thinking skills to make sound business decisions. The faculty were also asked which contracting courses had critical thinking related changes in course content, and if those changes led to improvements in the use of critical thinking by their students. Faculty members were asked to provide input on suggested improvements, whether a case-based critical thinking course would be beneficial, and any related topics requiring further research. The faculty survey is located at Appendix D - Contracting Faculty Survey. Survey attachments for both surveys are at Appendix E.

The research question “Does the current required Defense Acquisition Workforce Improvement Act contracting training address the training of critical thinking skills sufficient to implement Better Buying Power initiatives?” pertains to the current DAU contracting curriculum. Many of the faculty survey questions address the faculty’s recent experience (i.e. during the last three years, from FY 2013 - 2015). The start of this timeframe roughly corresponds to the release of BBP 2.0 (in November 2012 during FY 2013), which stressed acquisition workforce improvements. The workforce survey, however, requested information on each workforce member's personal experiences with courses where critical thinking skills were 
part of the curriculum. Since some of the more experienced workforce members might have been in the workforce before the 1990 DAWIA, some members of the contracting workforce might not have recent experience with the mandatory certification courses or experience with those courses after recent DAU curriculum changes.

\section{Data Collection}

Data for the research was collected using two surveys and an on-line review of current DAU mandatory contracting certification courses (as listed in the DAU iCatalog at http://www.dau.mil). To assist in the analysis of survey data, current DAU Contracting Level I, II, and III required certification courses were evaluated to determine if the courses address critical thinking skills in the descriptions or course objectives.

Two surveys were developed using the web-based Opinio software research tool. Both surveys included multiple choice, rating scale, and open ended questions and copies are located at Appendices C and D. Both surveys used the voluntary sampling method.

Headquarters (HQ) ACC G1 sent the workforce survey to the population of ACC government contracting personnel at the six ACC Contracting Centers, the Expeditionary Contracting Command (ECC), and the Mission and Installation Contracting Command (MICC) through the G1 training coordinators at each command. Contracting personnel, for the purposes of the research, are those coded as DA civilian job series 1102, military occupational specialty (MOS) codes 51C or 51Z, and local national C-1102 series. Workforce survey data collection was from 11 - 29 January 2016.

The South Region Associate Dean of Academics sent the faculty survey to the Associate Deans of Academics at the remaining DAU regions for subsequent distribution to the DAU 
contracting faculty members within their region. DAU faculty survey data collection was from 13 - 22 January 2016.

\section{Validity of the Research}

Numerical survey data was analyzed to determine averages for much of the survey data that was ranked by survey respondents. Data from open-ended survey responses provided information on potential improvements. Data analysis is discussed in Chapter four.

Validity of data collection. Survey responses for both surveys are believed to be valid data, representing only the intended target populations. Both surveys contained an initial screening question immediately after the Informed Consent certification question to ensure that survey participants were members of the intended population (i.e. ACC contracting personnel for the workforce survey and DAU Professors of Contract Management for the faculty survey). If survey participants were not members of the intended population, the survey ended at that point for those respondents. The collection of data was also impacted by an inclement weather event in the Northeastern United States during the collection period of each survey. Closures of several surveyed facilities did not affect data validity, but likely affected the number of responses received from several surveyed organizations (as further described in the response rate section).

Validity of data. The workforce survey demographic data indicates that five of the six ACC Contracting centers, the ECC, and the MICC were represented in the response data. DA civilians, military, and local national respondents were all represented in the survey data in roughly the same percentages as in the workforce population. The demographic data indicates that approximately two-thirds of the contracting workforce surveyed has less than ten years of contracting experience and roughly the same number attained at least one certification level within the last ten years as well. 
The DAU faculty survey demographic data indicates all respondents were Professors of Contract Management. Responses were received from four DAU regions: the Mid-Atlantic, South, Midwest, and West regions. Data indicates that $73 \%$ of respondents were male and $27 \%$ were female. Data on teaching experience shows that DAU contracting professors responding to the survey taught primarily at DAU, but several had other non-DAU teaching experience as well. The faculty data indicates varied professional experience from active duty, civilian, and industry. Full demographic data for both surveys is provided in Appendix F.

Figure 4 statistics apply to the ACC contracting workforce and DAU contracting faculty survey data:

\begin{tabular}{|l|l|l|}
\hline & $\begin{array}{l}\text { ACC Contracting } \\
\text { Workforce survey data }\end{array}$ & $\begin{array}{l}\text { DAU Contracting Faculty } \\
\text { survey data }\end{array}$ \\
\hline Population size & 5,230 (Note 1) & 101 (Note 2) \\
\hline $\begin{array}{l}\text { Sample size- number of } \\
\text { voluntary respondents } \\
\text { completing survey }\end{array}$ & 190 & 22 \\
\hline Response rate & $3.6 \%$ & $21.8 \%$ \\
\hline $\begin{array}{l}\text { Notes: } \\
\text { 1. Workforce population estimated by HQ ACC G1 on 17 December 2015 as being } 130 \text { (or } \\
\text { 2\%) Local National, 900 (or 17\%) Military, and 4200 (or 80\%) DA Civilians. } \\
\text { 2. Faculty population derived from DAU FY 15 TDA dated 4 January 2016. }\end{array}$ \\
\hline
\end{tabular}

Figure 4. Survey data statistics (Jones, 2016a, 2016b).

Validity of analysis. The researcher reviewed and analyzed the numerical survey data to determine averages for much of the ranked survey data. Data from open-ended responses provided information on potential improvements and are summarized when possible. Data analysis is discussed in chapter four.

\section{Limitations of the Study}

Applicability of research to DoD or Army. The results of this research may not apply to the other DoD services’ or the entire Army contracting workforce. The workforce data 
collected during this research was obtained from the ACC contracting workforce, which makes up approximately $70 \%$ of the Army contracting workforce, but is not necessarily representative of the entire Army's contracting workforce. Data from the other services and non-ACC Army commands was not obtained for this research study.

The DAU faculty survey data has greater application to DoD overall. The DAU contracting professors responding to the survey teach contracting students from all DoD services. The faculty survey questions were generic to the faculty’s DAU contracting instruction experiences and questions did not attempt to single out Army or ACC contracting students in any way.

Response rate. Another limitation of the study is the response rate for the workforce survey of 3.6\%. Out of the approximately 5,230 ACC contracting personnel, only 190 submitted completed surveys. Eighteen others indicated that they did not wish to take the survey or did not complete most responses. Due to non-availability of direct contact information for all ACC contracting personnel, HQ ACC G1 requested that ACC training officers forward the survey to their ACC contracting personnel at ACC locations worldwide. Likewise, contact information for DoD and Army contracting personnel was not available for the research. Additionally, several of the ACC contracting activities located in the Northeast were closed for a portion of the survey period due to inclement weather, which may have adversely affected the response rate.

The faculty survey had a response rate of $21.8 \%$. Of the 101 DAU contracting professors on the most recent DAU Table of Distribution and Allowances (TDA), 22 completed the survey. The weather related closure of DAU campuses in the Northeast during some of the survey period may have also adversely affected the faculty survey response rate. 
Survey method. The voluntary sample method was selected for both surveys due to its convenience and low cost. According to the Stat Trek Statistics and Probability Dictionary, the voluntary sampling method is a non-probability sampling method where the sample consists of people who self-select into the survey (Stat Trek, 2016). Stat Trek (2016) explains that nonprobability sampling methods do not allow researchers to make probability statements about the certainty of the sample accurately representing the surveyed population.

Recency of contracting workforce experience. As indicated in the research method discussion of the workforce survey, it is likely that the majority of the more experienced members of contracting workforce will not have much recent experience with the mandatory contracting certification courses as they were certified at Contracting Level III more than three years ago. The lack of current experience with DAU contracting courses increases the difficulty in gauging the effectiveness of the current curriculum's critical thinking training in these members of the workforce.

Meaning of critical thinking. People have different interpretations of the meaning of critical thinking and the six critical thinking skills (interpretation, analysis, inference, evaluation, explanation, and self-regulation) that were studied in the research. Common definitions of critical thinking and the six critical thinking skills were provided in the survey to minimize varying meanings for these concepts among the respondents. Definitions are found in Appendix E - Survey Attachments. The next section discusses the research findings for the ACC contracting workforce and DAU faculty surveys and analysis of the DAU contracting curriculum. 


\section{Chapter 4 - Findings and Analysis}

Data was received and compiled from both the contracting workforce and DAU contracting faculty online surveys. Appendices C and D are copies of the online surveys and Appendix E are the survey attachments. Appendix F contains the demographic data for each survey. The findings and analysis of the data for both surveys are presented below. An analysis of the current contracting courses’ critical thinking training content is also included in this section.

\section{Contracting Workforce Survey Findings}

The intent of the workforce survey was to determine the ACC contracting workforce’s perceptions on

- $\quad$ sources of critical thinking training and the effectiveness of critical thinking training received;

- methods to make critical thinking training more effective;

- reasons for some members of the workforce not taking critical thinking training;

- the availability of adequate training opportunities;

- the importance of critical thinking skills;

- the validity of critical thinking assessments as valid measures; and

- $\quad$ the frequency of using critical thinking skills to implement BBP initiatives.

Critical thinking training methods and average effectiveness. The ACC contracting workforce was asked if they had experienced critical thinking training using a variety of training methods. Figure 5 shows responses for the methods of critical thinking training the 190 workforce respondents had experienced. 
An analysis of the data on the workforce experience with various training methods indicates that the most prevalent type of critical thinking training received by the workforce was in formal education (college courses), followed by on-the-job contracting training, self-taught methods, and DAU contracting certification courses. Other learning methods cited by workforce members included attending Civilian Education System (CES) courses; being raised in an environment that valued critical thinking; conducting research in college and on the job;

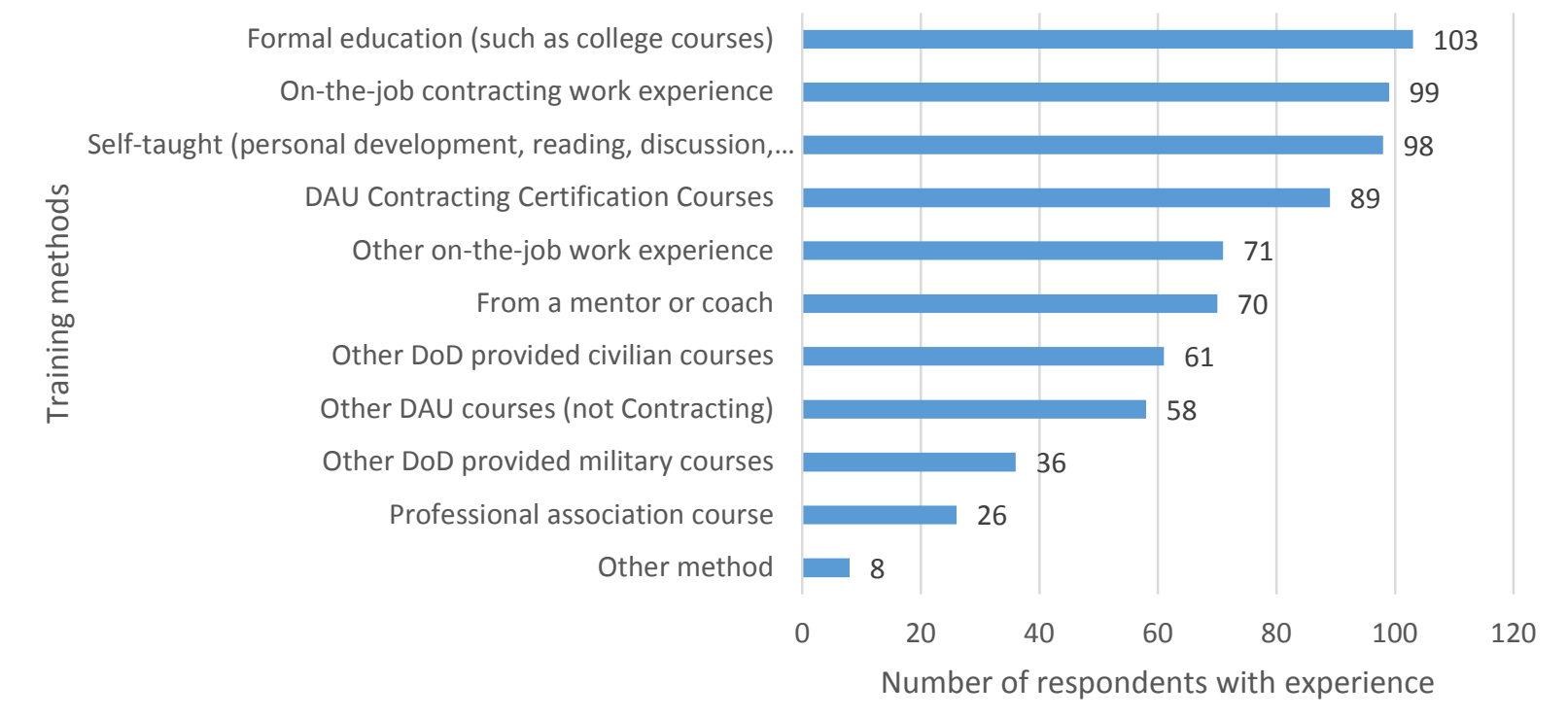

Figure 5. Experience with training methods (workforce) (Jones, 2016b).

participating in the internship program; and attending leadership programs (including the Excellence in Government Fellows Program and Acquisition Leadership Challenge II).

For the types of training they had participated in, the workforce was asked to rank the effectiveness of the training on a ranking scale of 1 to 7 where

- 1 = totally ineffective,

- $\quad 2$ = ineffective,

- $\quad 3$ = somewhat ineffective,

- 4 = neither effective nor ineffective, 
- 5 = somewhat effective,

- 6 = effective, and

- $\quad 7$ = extremely effective.

Figure 6 gives the average ranking for each critical thinking training method experienced by the contracting workforce, with the most effective training methods at the top of the figure.

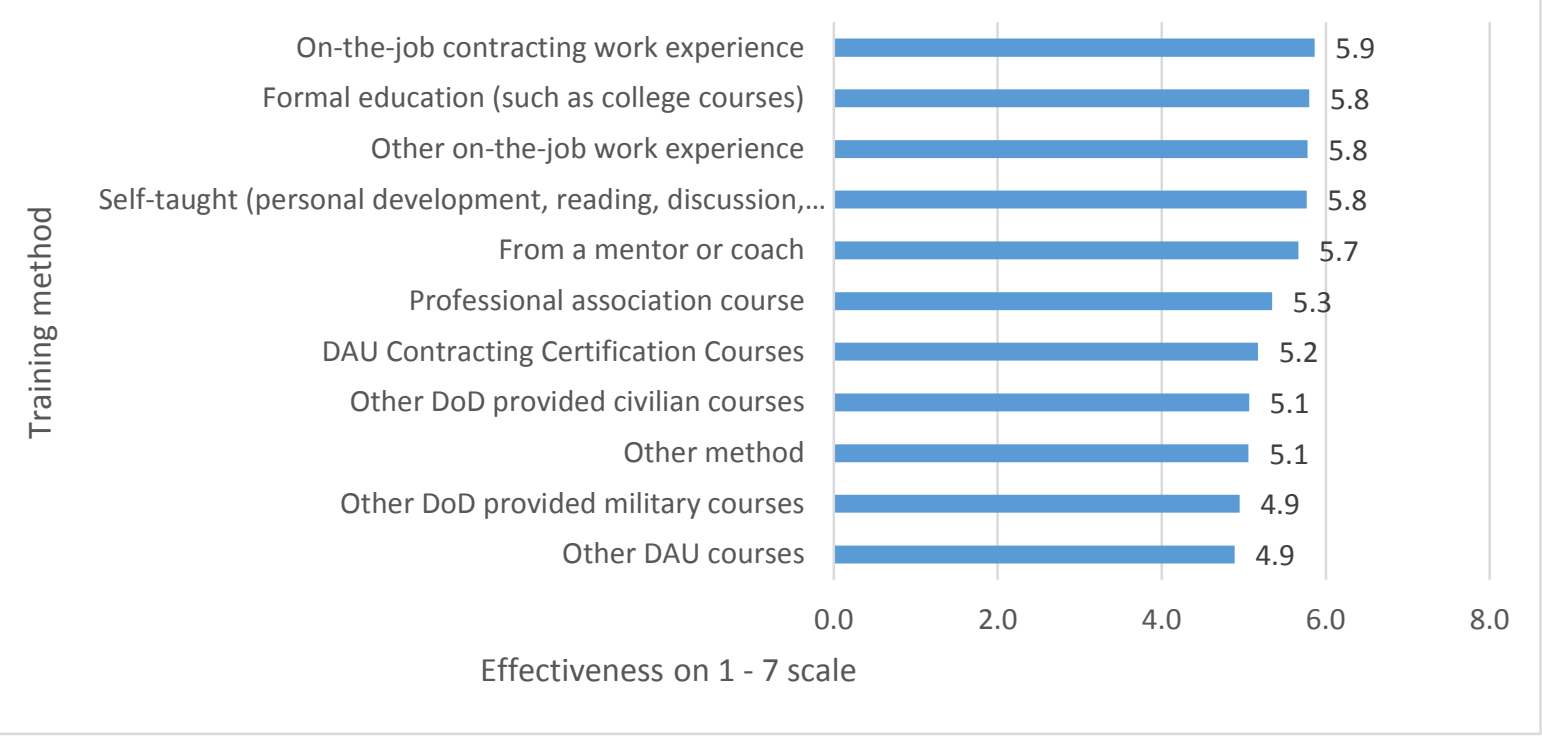

Figure 6. Effectiveness of training methods (workforce) (Jones, 2016b).

On-the-job work experience rates highest in training effectiveness for learning critical thinking skills. The average effectiveness of the listed methods is 5.4. Mentoring or coaching rates higher than average in effectiveness with the workforce while courses in general rank below average in effectiveness with the workforce.

Of those workforce members receiving critical thinking training, 83\% of the respondents indicated that they thought their critical thinking skills improved as a result of the training received.

Increasing the effectiveness of critical thinking training. The ACC contracting workforce was asked their opinions on methods that would make critical thinking training more 
effective. Figure 7 indicates the preferred methods to increase training effectiveness, with hands-on exercises, more case-based and simulation training, and more interaction in the classroom being the most cited means of increasing critical training effectiveness.

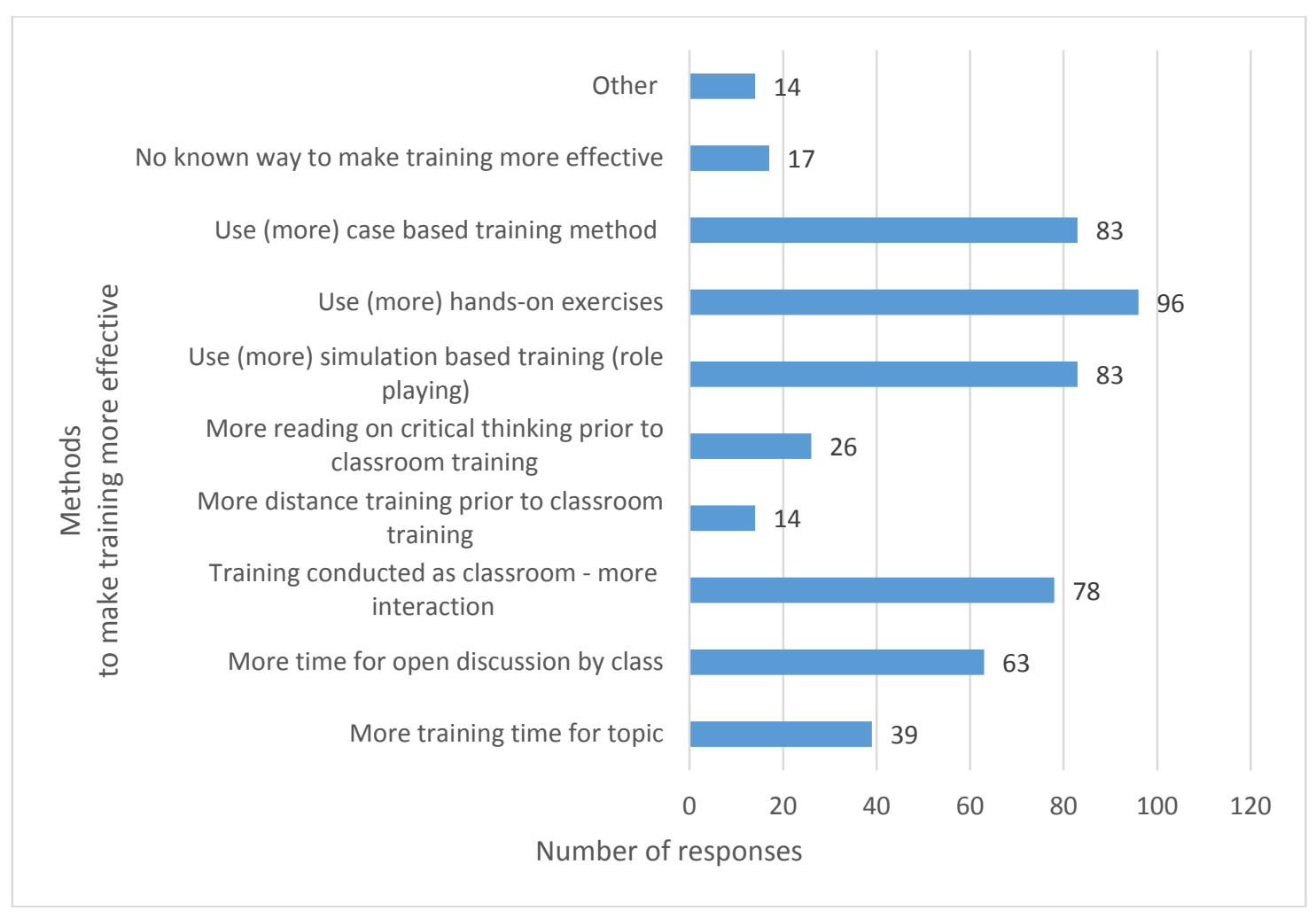

Figure 7. Methods to increase training effectiveness (workforce) (Jones, 2016b).

Reasons for not taking critical thinking training. Of the respondents who had not received critical thinking training, the questions asked reasons they had not taken a course that included the application of critical thinking skills and/or tools. The results (illustrated in 


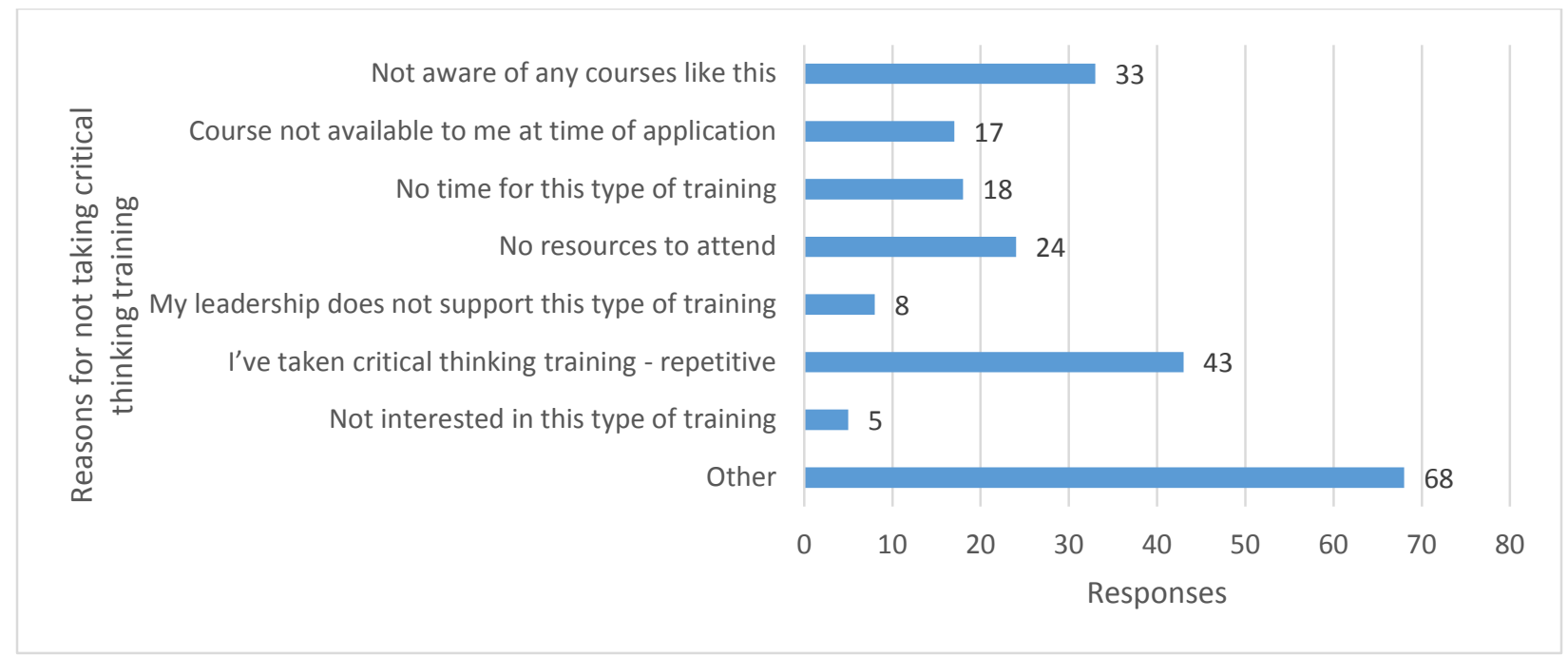

Figure 8. Reasons for not taking critical thinking training (workforce) (Jones, 2016b).

Figure 8) indicated that common reasons for not attending critical thinking training included lack of resources (time and funding) and awareness of such training. Much of the workforce, providing “other comments,” indicated they had taken similar training already.

Adequacy of training opportunities. The ACC contracting workforce was asked if they thought adequate opportunities for contracting personnel certified at Contracting Level III existed to obtain additional training to enhance their critical thinking skills. The 118 respondents who were Level III certified (62\% of the survey population) gave responses to the question as indicated in Figure 9. Only 43\% of the respondents indicated there were adequate training opportunities. 


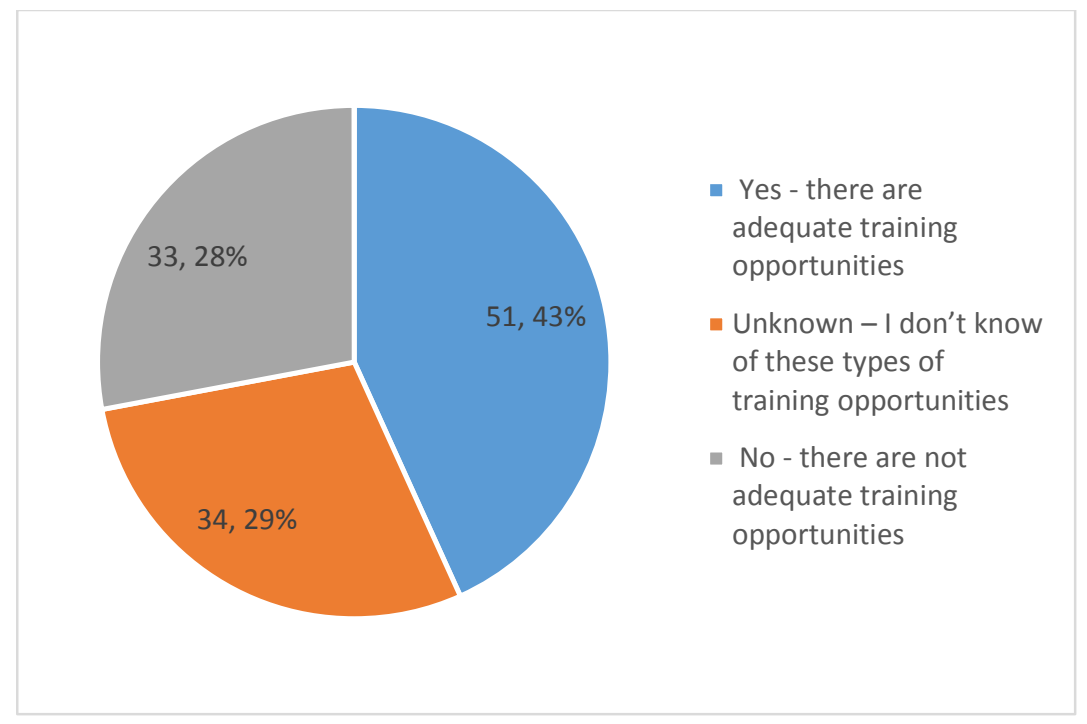

Figure 9. Adequacy of training opportunities (workforce) (Jones, 2016b).

Effective training methods. The contracting workforce was asked what training methods were the most effective in enhancing critical thinking skills. Hands-on analysis and other similar hands-on exercises and case studies were ranked as effective training methods by the respondents. The responses are indicated in Figure 10. Other effective training

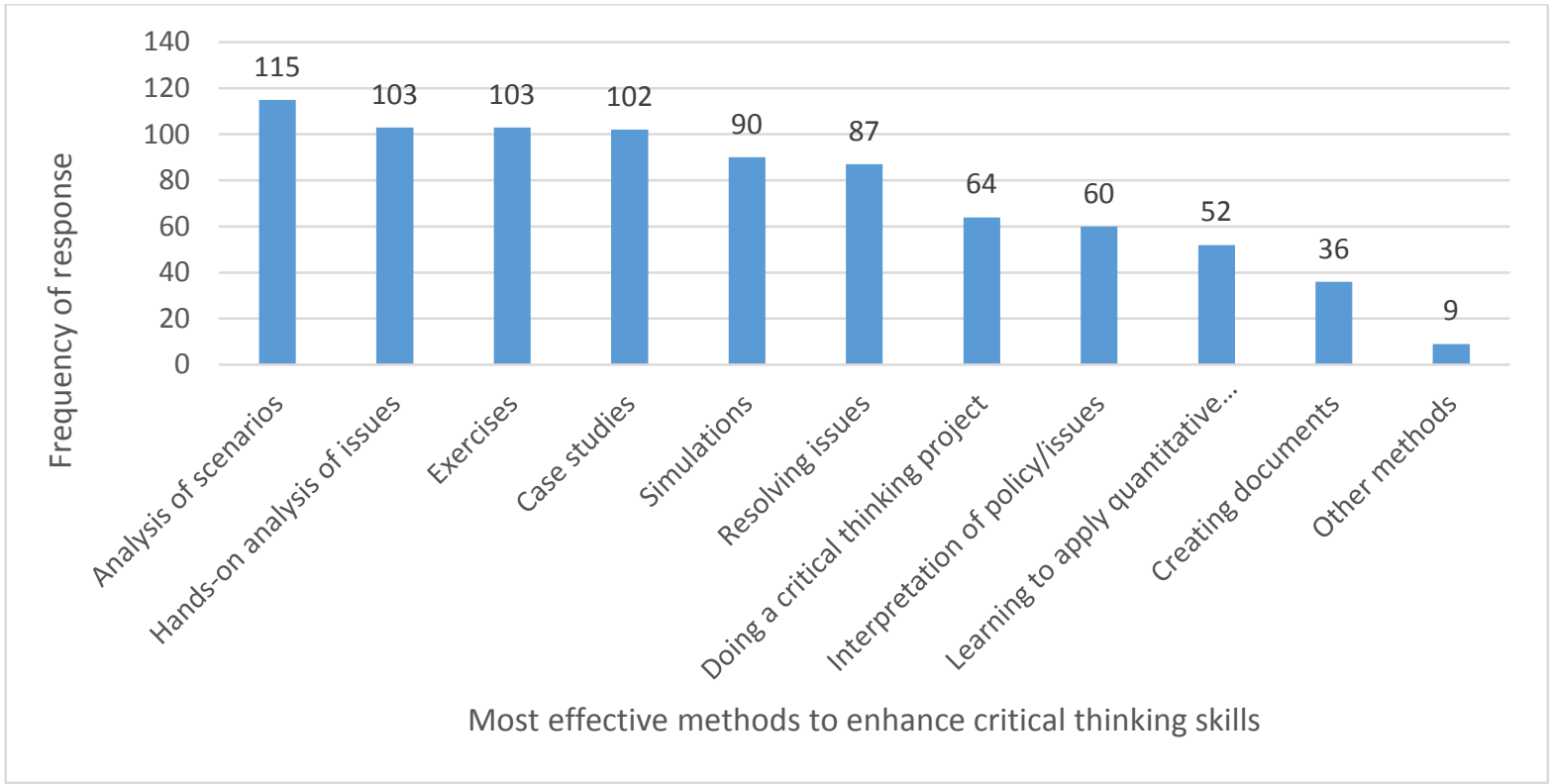

Figure 10. Most effective training methods (workforce) (Jones, 2016b). 
methods noted by the workforce respondents were resident classes, practical experience in work situations with good critical thinkers and mentors, and incorporating these more effective training methods into existing Level II and III contracting classes.

Importance of critical thinking skills. The ACC contracting workforce survey questioned respondents regarding which critical thinking skills they thought were important to make sound business decisions or understand complex contracting issues. The workforce respondents were asked to rank each listed skill using the ranking scale

- 1 = totally unimportant,

- 2 = unimportant,

- 3 = somewhat unimportant,

- 4 = neither important nor unimportant,

- 5 = somewhat important,

- 6 = important, and

- 7 = very important.

Skill definitions, as listed in Appendix E, were provided to the workforce for use in the question. Figure 11 provides the average skills rankings the contracting workforce assigned to the various critical thinking skills. An average overall ranking of the six skills is also provided.

Respondents ranked analysis and evaluation as the most important. Respondents ranked the least important skills as being inference and self-regulation, skills important in the tasks of selecting relevant information for decision-making and validating reasoning or judgements. 


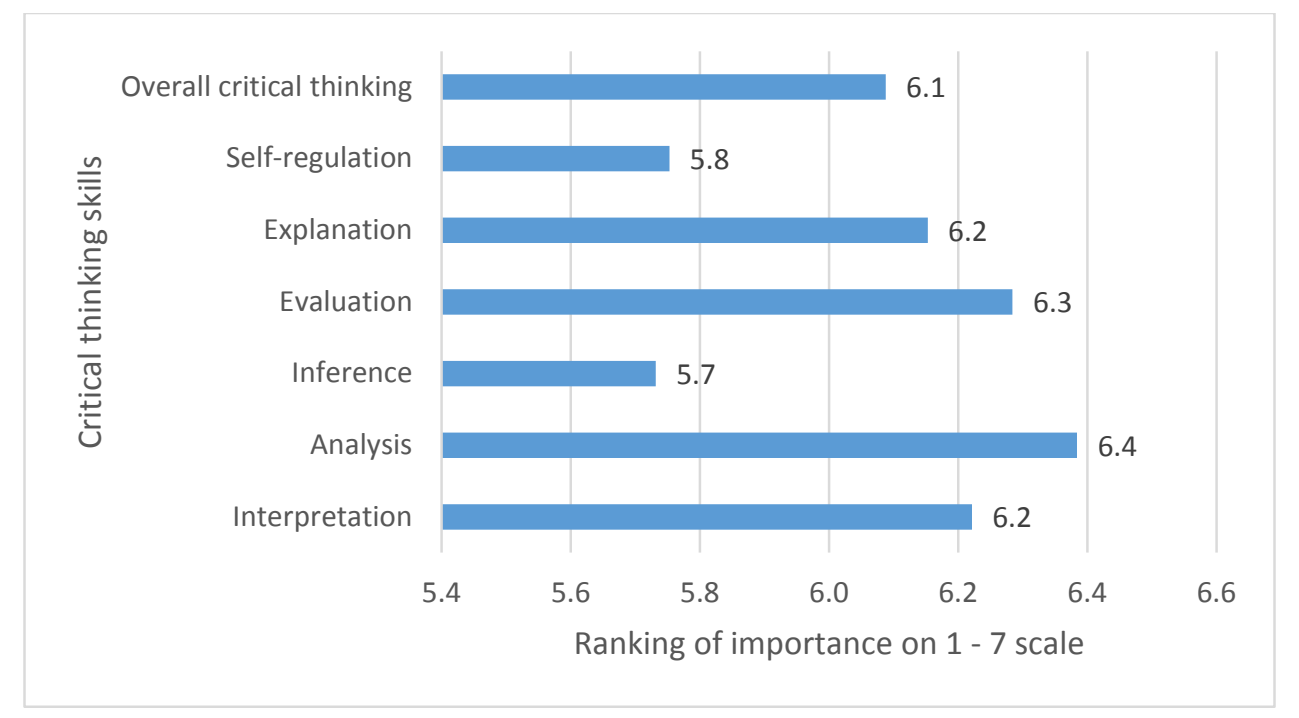

Figure 11. Average importance of critical thinking skills (workforce) (Jones, 2016b).

Assessment of critical thinking skills. The ACC contracting workforce was asked if they had ever had an assessment of their critical thinking skills. The 46 workforce members that had participated in such an assessment were asked about the accuracy of the assessment. Figure 12 shows the breakdown of the workforce having participated in a skills assessments. Figure 13 indicates the perceived high accuracy of the skills assessment testing.

Figure 12. Skills assessment (workforce) (Jones, 2016b). 


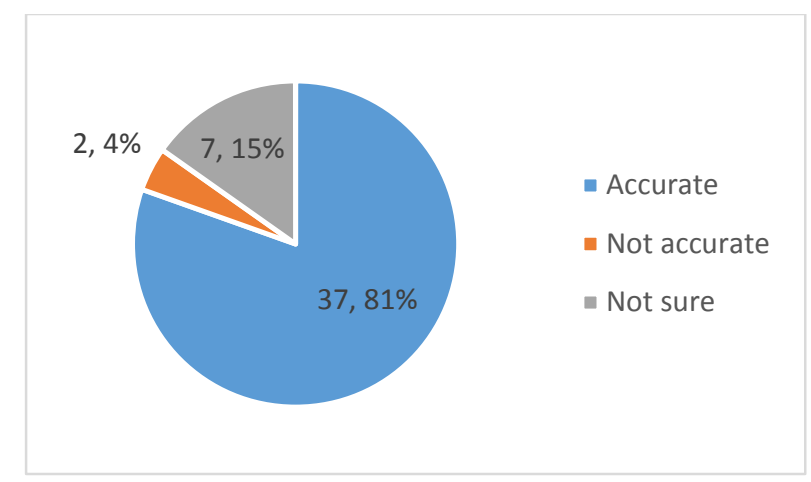

Figure 13. Accuracy of skills assessment (workforce) (Jones, 2016b).

Disposition to use critical thinking skills. The ACC contracting workforce survey questioned if the respondents had ever been assessed on their disposition to use critical thinking skills. The 26 workforce members who responded they had been assessed on having a disposition to use critical thinking skills were then asked if the assessment was accurate and the method used for the assessment. Figure 14 shows the percentage and number of ACC workforce members having an assessment pertaining to the participant's disposition to think critically. Figures 15 and 16 represent the perceived accuracy of the disposition assessment and the assessment method used to assess the disposition to use critical thinking skills in the 26 workforce members who had this type of assessment.

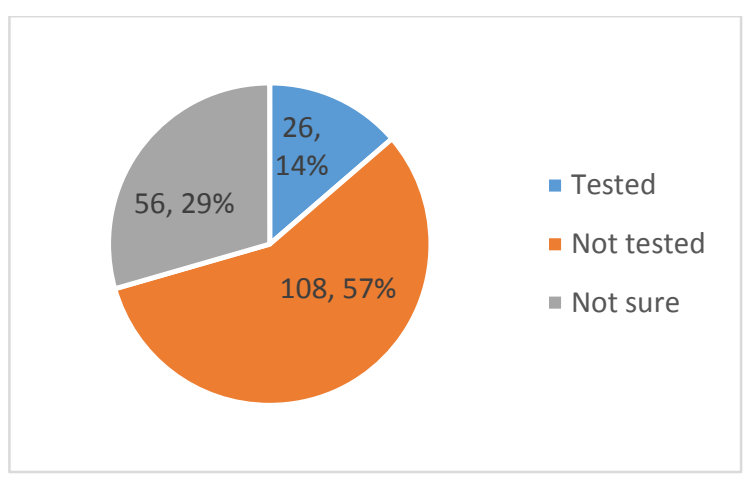

Figure 14. Disposition assessment (workforce) (Jones, 2016b). 


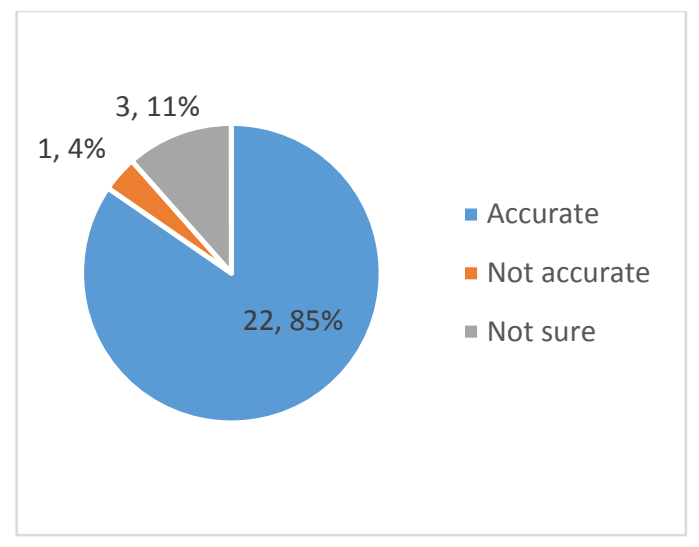

Figure 15. Accuracy of disposition assessment (workforce) (Jones, 2016b).

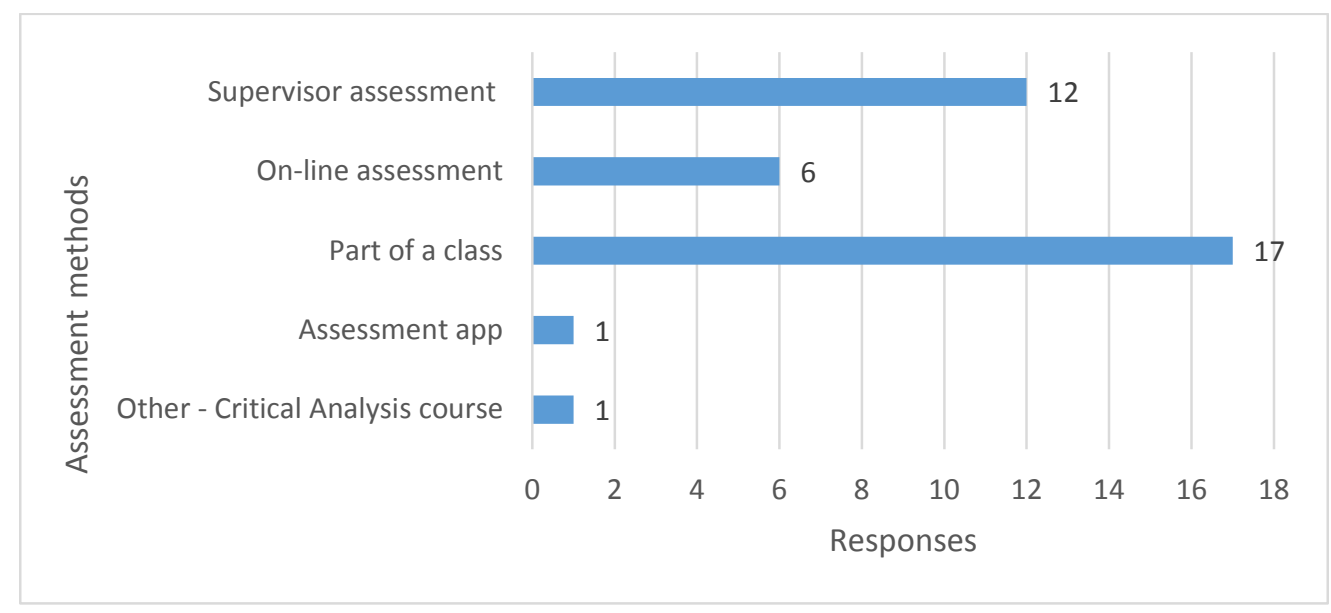

Figure 16. Disposition assessment methods (workforce) (Jones, 2016b).

Frequency of use of critical thinking skills in complex contracting issues. A question pertaining to the contracting workforce’s involvement with complex contracting tasks requested that respondents rank the frequency of use of critical thinking skills when they were performing these various tasks. The list of issues was derived from the Better Buying Power 3.0 initiatives that could involve contracting personnel. Figure 17 illustrates the contracting workforce's involvement in various BBP initiatives. The data is arranged by the most frequently reported BBP tasks performed by the contracting workforce. 


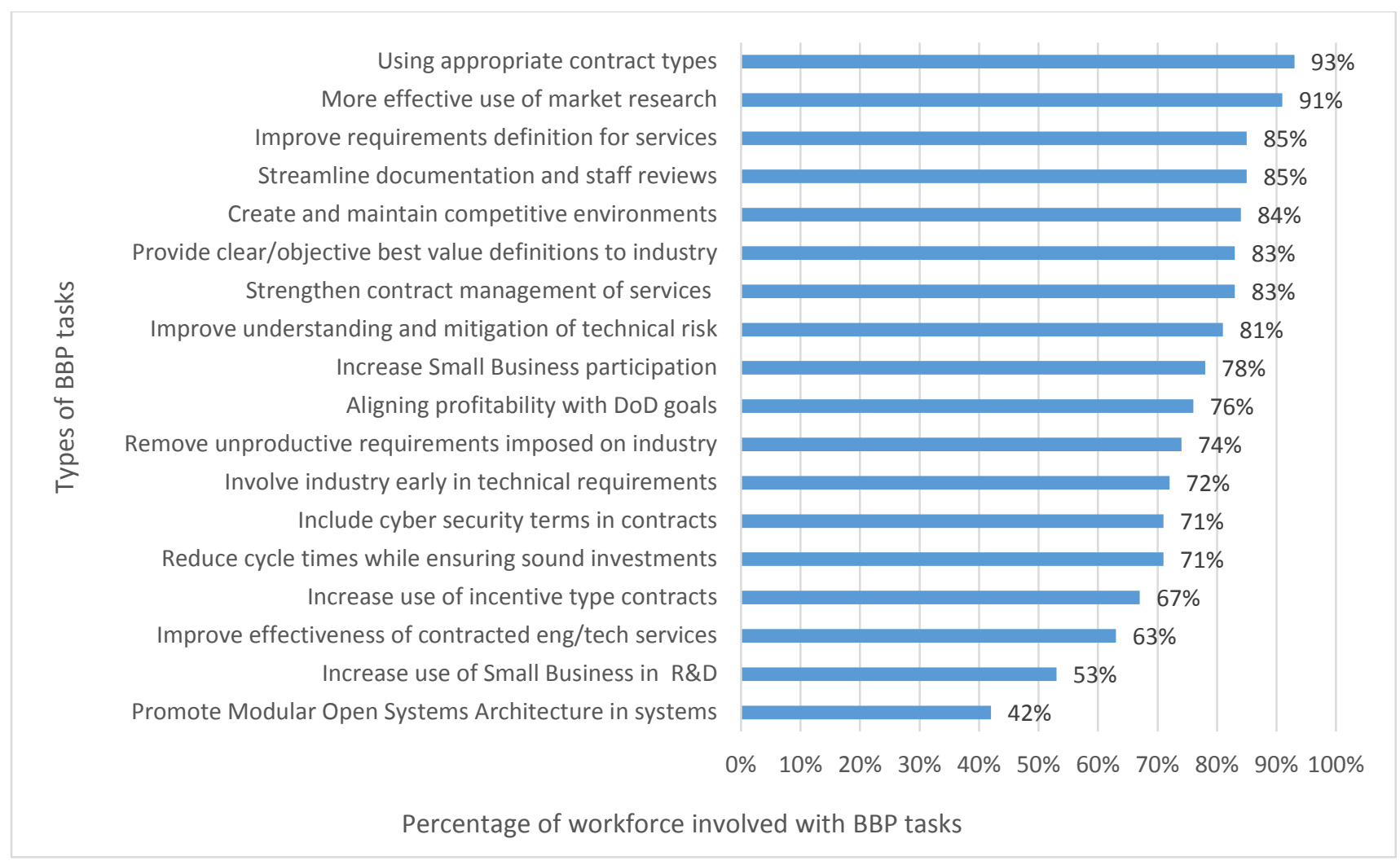

Figure 17. Involvement in BBP contracting issues (workforce) (Jones, 2016b).

Figure 18 shows the participant's ranking of the average frequency of use of critical thinking skills for the same listing of BBP contracting issues. The scale used to rank the frequency of critical thinking skills use when processing these BBP issues was

- 1 = never use,

- 2 = infrequently use,

- 3 = don’t routinely use,

- 4 = sometimes use,

- 5 = frequently use,

- 6 = almost always use, and

- $\quad 7$ = always use 


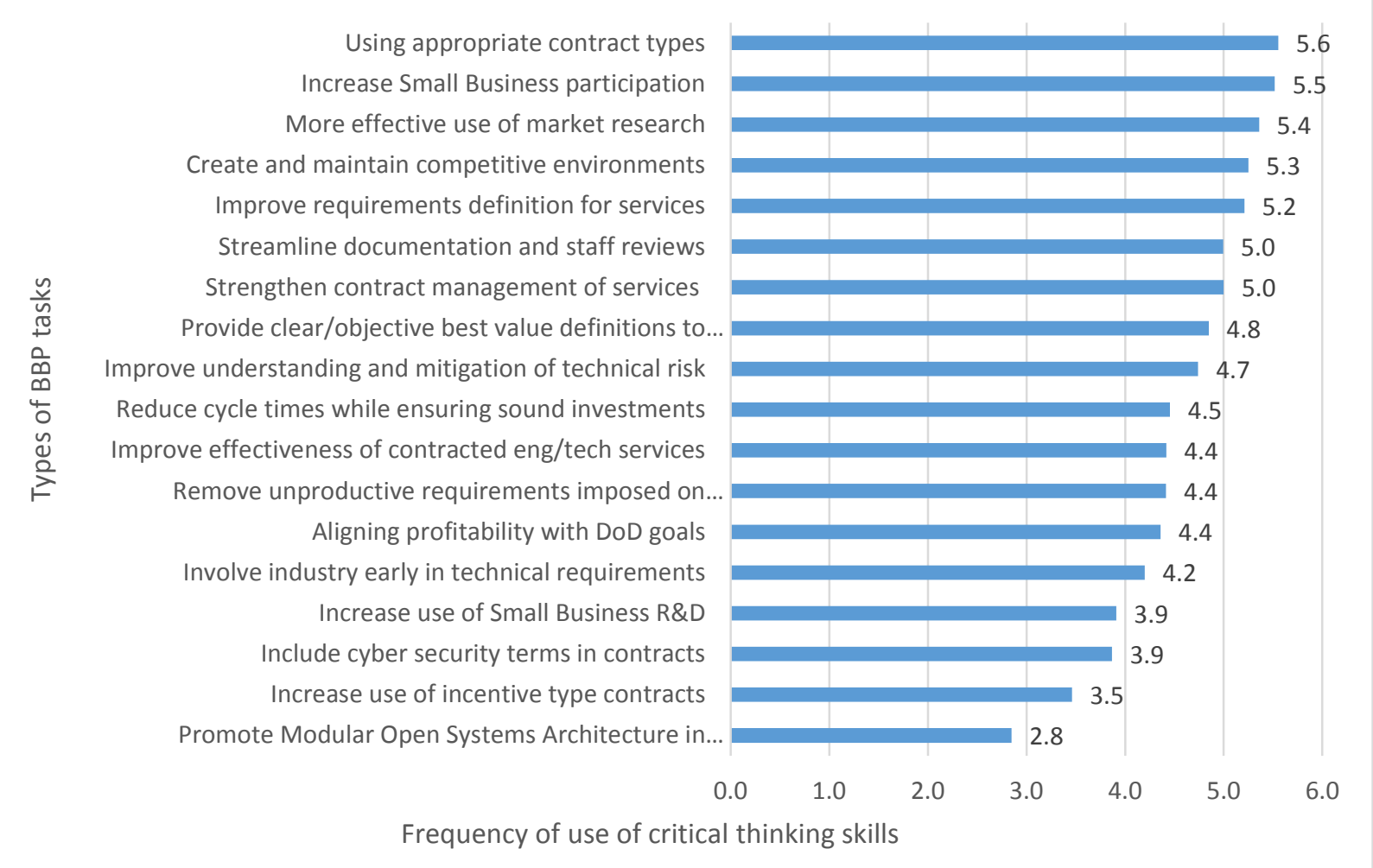

Figure 18. Frequency of critical thinking skills used for BBP issues (workforce) (Jones, 2016b).

The average for all the listed tasks in Figure 18 was 4.6, indicating that the average use of critical thinking skills for all the listed BBP tasks is between sometimes used (a 4 ranking) and frequently used (a 5 ranking) for the survey participants. The results indicate room for improvement in employing critical thinking skills within the contracting workforce.

\section{Contracting Faculty Survey Findings}

The intent of the contracting faculty survey was to determine DAU faculty perspectives regarding

- the effectiveness of critical thinking training in the DAU courses with critical thinking skills in the curriculum;

- observations of students demonstrating critical thinking skills in the classroom in the DAU courses with critical thinking skills in the curriculum; 
- critical thinking training methods DAU faculty members were the most effective in teaching critical thinking skills;

- the adequacy of critical thinking skills in the contracting workforce to implement sound business decisions and the identification of areas for improvement in critical thinking skills;

- improvements in critical thinking skills as a result of DAU course revisions; and

- ideas for improvements in critical thinking training.

Is the critical thinking training in the contracting curriculum effective? The DAU faculty survey had a series of questions pertaining to recent involvement with Level I, II, and III mandatory contracting certification courses with critical thinking skills in the curriculum. For the purposes of the survey, recent experience was defined as the last three years (or FYs 2013 - 2015). Figure 19 lists the courses that at least one faculty member reported recent experience with that, in the faculty member's opinion, included some critical thinking component. Figure 19 is based on the responses of the 22 faculty members who responded to the faculty survey. Appendix B, containing descriptions of the courses in the contracting curriculum, was distributed with the survey to assist faculty members in identifying courses with critical thinking components.

For each course listed in Figure 19, the DAU contracting faculty members with recent experience in the courses then ranked the effectiveness of the critical thinking curriculum in each course using a ranking scale where

- 1 = very ineffective,

- 2 = ineffective,

- 3 = somewhat ineffective, 
- 4 = neither effective nor ineffective,

- 5 = somewhat effective,

- 6 = effective, and

- 7 = very effective.

\begin{tabular}{|c|l|c|}
\hline Level & Course & $\begin{array}{c}\text { Faculty with } \\
\text { recent } \\
\text { course } \\
\text { experience }\end{array}$ \\
\hline I & CON 090-Federal Acquisition Regulation Fundamentals & 10 \\
\hline I & CON 100-Shaping Smart Business Arrangements & 4 \\
\hline I & CON 121-Contract Planning & 4 \\
\hline I & CON 124-Contract Execution & 5 \\
\hline I & CON 127-Contract Management & 4 \\
\hline I & CON 170-Fundamentals of Cost and Price Analysis & 11 \\
\hline I & CLC 025-Small Business Program for Contracting Officers & 1 \\
\hline & CLC 033-Contract Format \& Structure for DoD eBusiness & 1 \\
\hline I & CLC 057-Performance Based Payments \& Value of Cash Flow & 7 \\
\hline I & CLC 058-Introduction to Contract Pricing & 5 \\
\hline II & CON 200-Business Decisions for Contracting & 4 \\
\hline II & CON 216-Legal Considerations in Contracting & 2 \\
\hline II & CON 270-Intermediate Cost and Price Analysis & 12 \\
\hline II & CON 280-Source Selection \& Administration of Service Contracts & 9 \\
\hline II & CON 290-ContractAdministration \& Negotiation Techniques in a & 6 \\
\hline II & Supply Environment & 2 \\
\hline II & CLC 051-Managing Government Property in the Possession of & 2 \\
\hline II & HBC 056-Analyzing Contract Costs & 5 \\
\hline III & CON 360-Contracting for Decision Makers & 2 \\
\hline III & ACQ 256-Mission Focused Services Acquisition & 2 \\
\hline III & ACQ 315-Understanding Industry (Business Acumen) & 2 \\
\hline III & ACQ 370-Acquisition Law & 2 \\
\hline III & CON 232-Overhead Management of Defense Contracts & 2 \\
\hline III & CON 244-Construction Contracting & 2 \\
\hline III & CON 252-Fundamentals of Cost Accounting Standards & \\
\hline III & CON 334-Advanced Contingency Contracting Officer's Course & \\
\hline III & CON 370-Advanced Contract Pricing & 2 \\
\hline & & 2 \\
\hline
\end{tabular}

Figure 19. Recent courses with critical thinking (faculty) (Jones, 2016a).

Figures 20 - 22 give the average curriculum effectiveness ranking for each Level I, II, and III contracting course, as determined by DAU faculty survey participants. To assist in the analysis 
of the data in Figures 20 -22, a calculation of the overall average curriculum effectiveness ranking (using the average of all the listed courses in a level) is provided for each certification level.

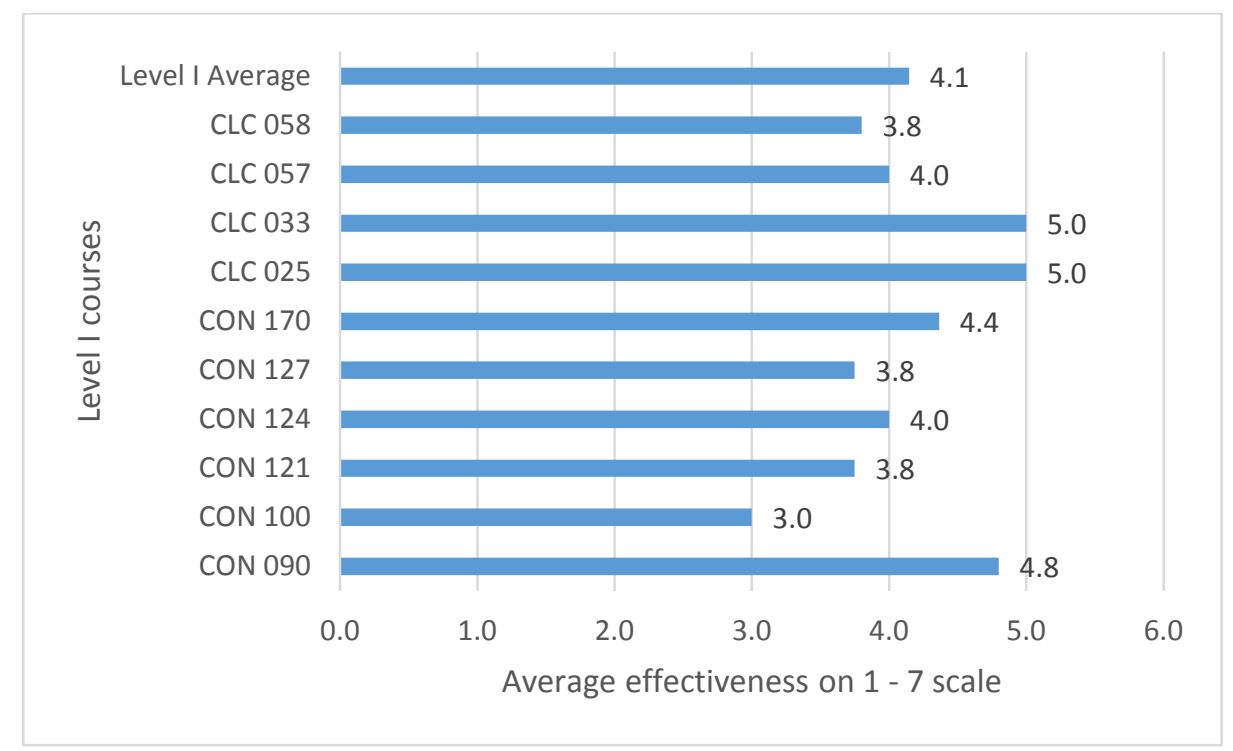

Figure 20. Level I courses - critical thinking curriculum effectiveness (faculty) (Jones, 2016a).

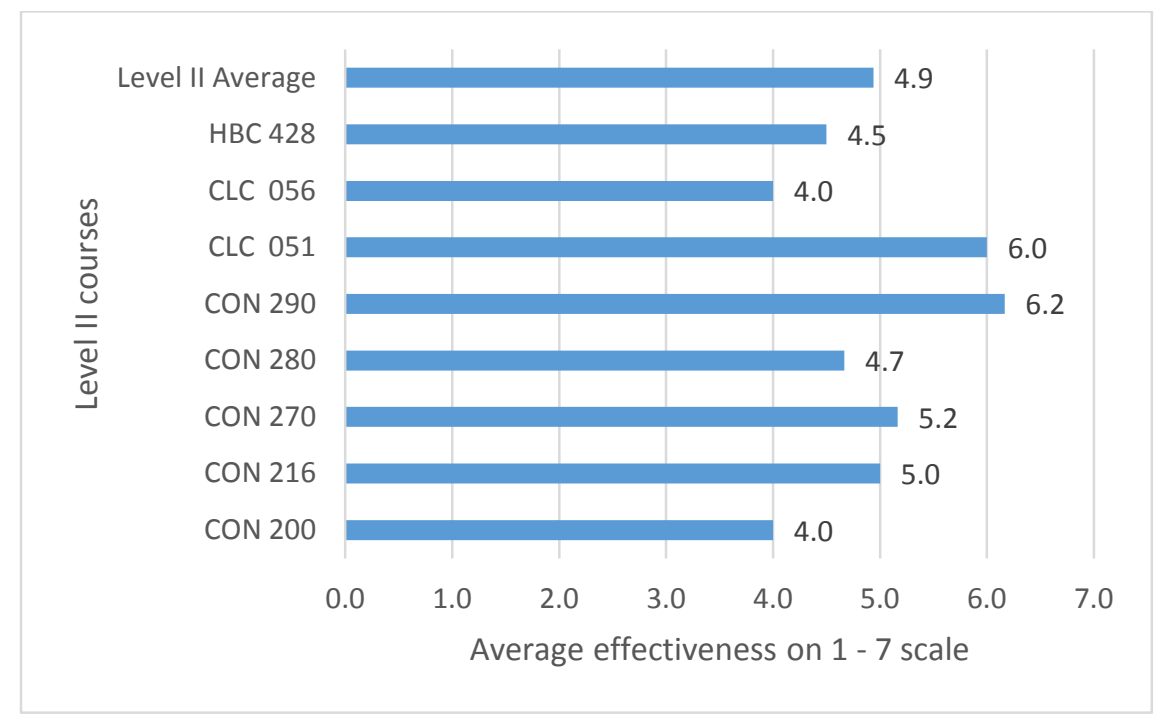

Figure 21. Level II courses - critical thinking curriculum effectiveness (faculty) (Jones, 2016a). 


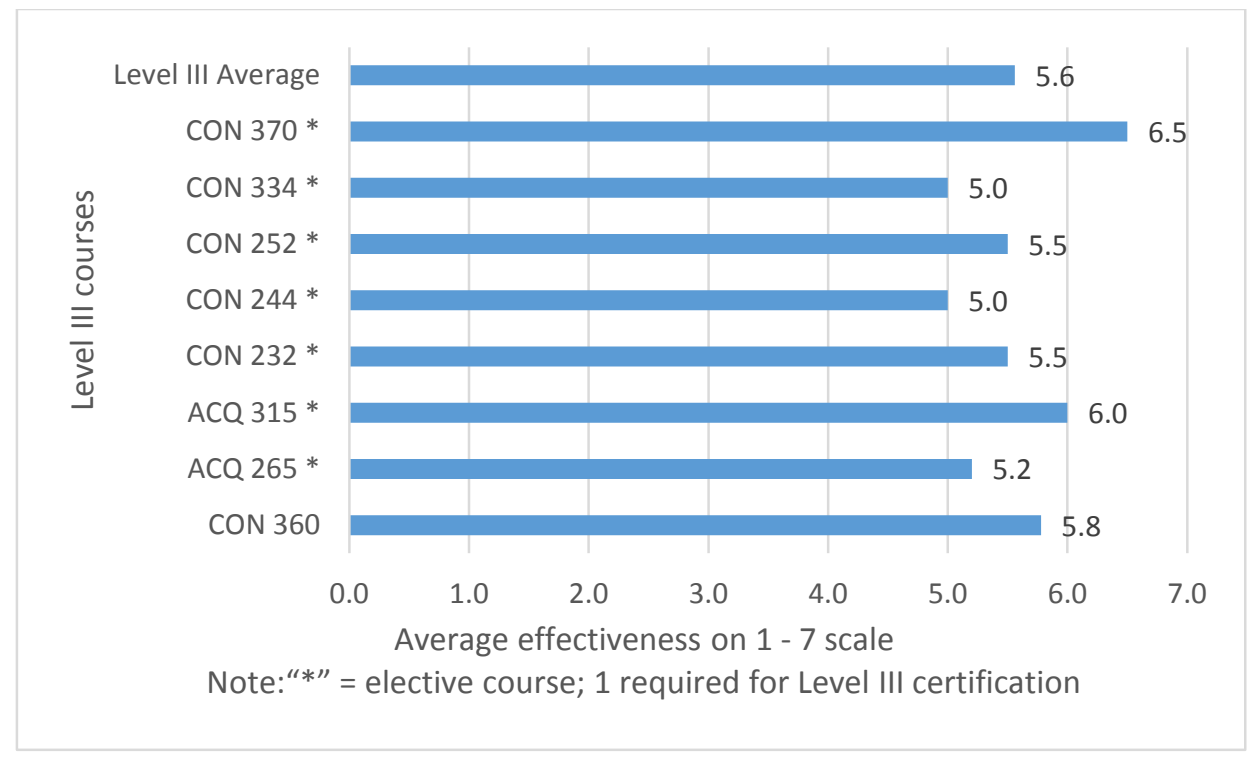

Figure 22. Level III courses - critical thinking curriculum effectiveness (faculty) (Jones, 2016a).

Figure 23 illustrates the increase in the perceived effectiveness and ranked average overall effectiveness of the critical thinking curriculum at each certification level. The critical thinking curriculum effectiveness (based on a 7-point scale) increased with each contracting certification level.

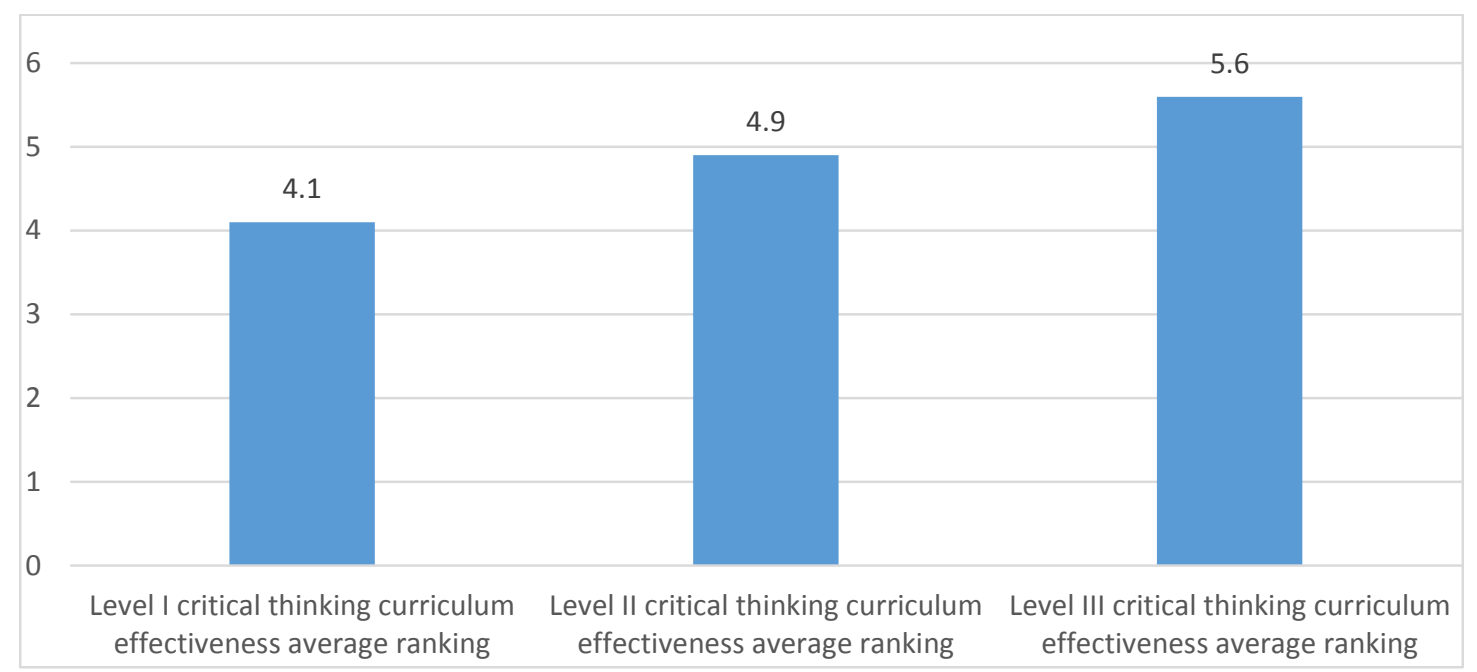

Figure 23. Overall average effectiveness of Level I, II \& III courses (faculty) (Jones, 2016a).

Are critical thinking skills observed in the contracting classroom? The survey requested that DAU contracting faculty members with recent experience teaching Level I, II, and 
III contracting classes rank the extent they observed the six core critical thinking skills being exhibited in contracting classes. Survey participants ranked the core critical thinking skills (interpretation, analysis, inference, evaluation, explanation, and self-regulation) as described in the Delphi report (and as listed in Appendix E). Rankings were based on a scale of 1 to 7 where

- 1 = no critical thinking skills exhibited,

- 2 = few critical thinking skills exhibited,

- 3 = some critical thinking skills exhibited,

- 4 = average critical thinking skills exhibited,

- 5 = above average critical thinking skills exhibited,

- 6 = many critical thinking skills exhibited, and

- 7 = extensive critical thinking skills exhibited.

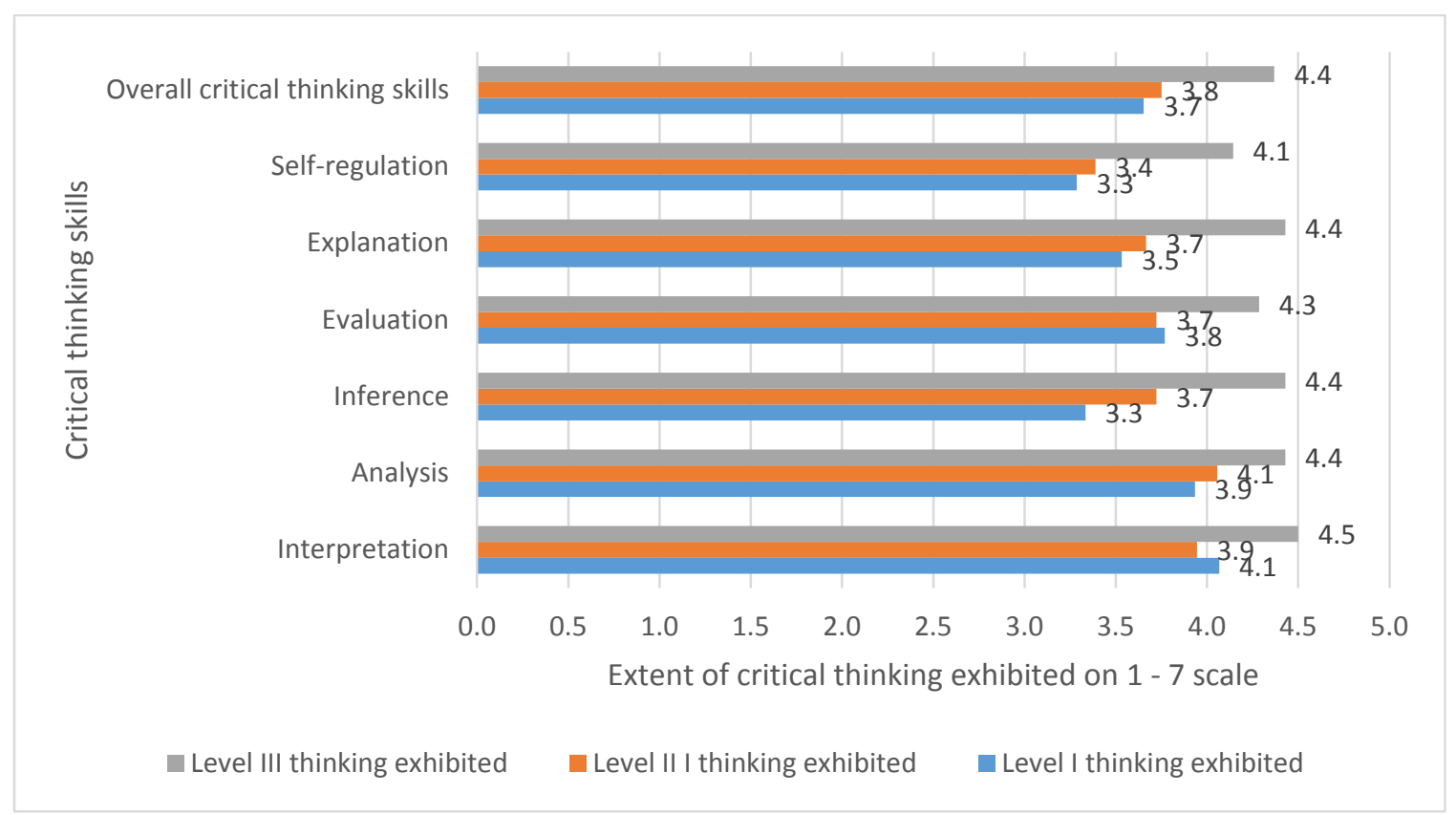

Figure 24. Extent critical thinking skills exhibited in Level I, II, \& III classes (faculty) (Jones, 2016a).

The ranking data from respondents on the three survey questions on the six observed critical thinking skills at each level of classes appears in Figure 24. The overall data represents 
an average of the faculty rankings for the six listed critical thinking skills observed in their classes at each contracting certification level. An analysis of the data in Figure 24 indicates that the contracting faculty observed an increase in exhibited critical thinking skills in classes at each certification level. The data also indicates the highest observed critical thinking skill (interpretation) was 4.5 on a scale of 7 , a ranking of between average and above average. The lowest rankings (for self-regulation and inference) were 3.3 - equivalent to some critical thinking skills being exhibited.

\section{What are the most effective training methods to teach critical thinking skills? DAU}

Contract Management professors ranked their perceptions of the general effectiveness of various methods used for teaching critical thinking skills. Rankings were based on a ranking scale of 1 to 7 where

- 1 = very ineffective,

- 2 = ineffective,

- 3 = somewhat ineffective,

- 4 = neither effective nor ineffective,

- 5 = somewhat effective,

- 6 = effective, and

- 7 = very effective.

The survey data effectiveness rankings were averaged for each training method and appear in Figure 25. The survey provided an option for faculty responses for training methods other than those listed in Figure 25. 


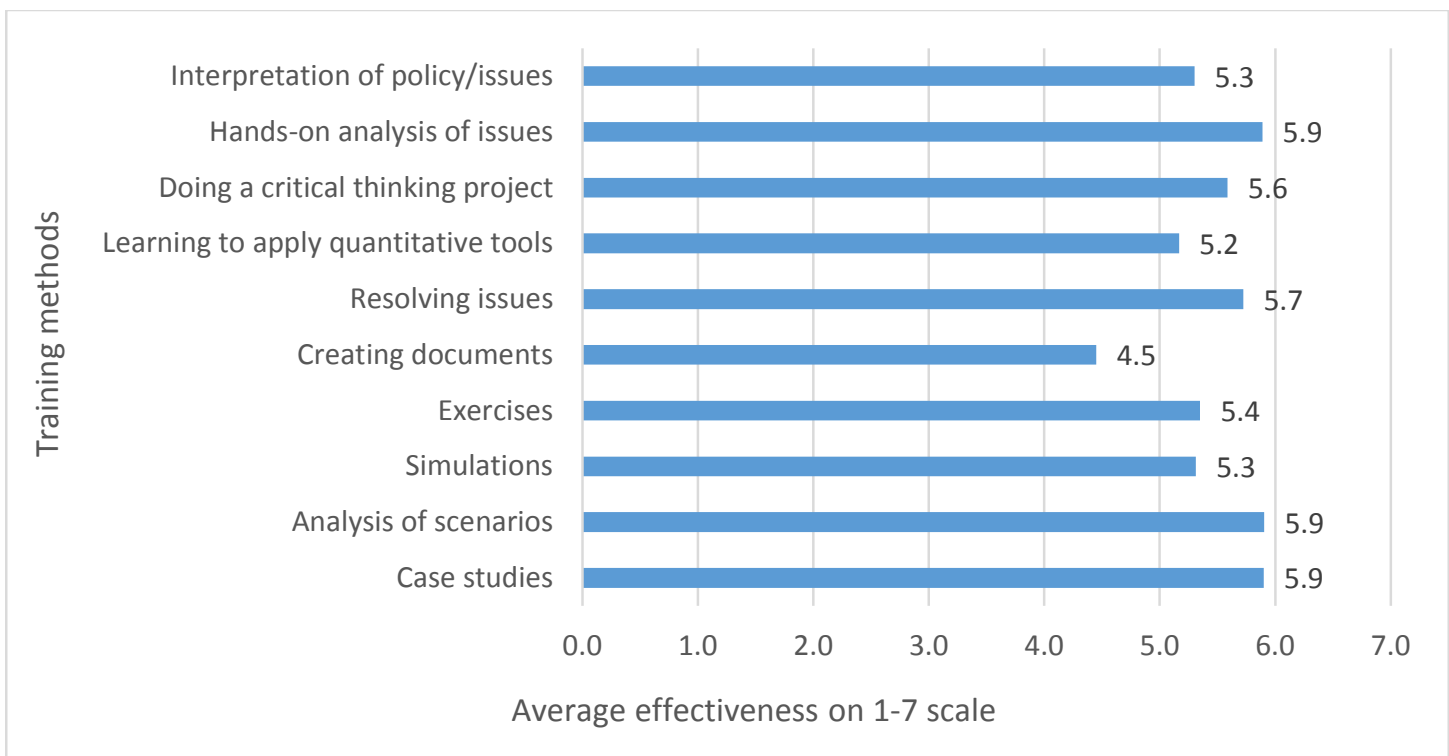

Figure 25. Average effectiveness of critical thinking skills training methods (faculty) (Jones, 2016a).

The use of properly facilitated classroom discussions was noted by one faculty member as another effective training method for teaching critical thinking skills. An analysis of the data presented in Figure 25 indicates, on average, the DAU contracting faculty surveyed indicated case studies, analysis of scenarios, and hands-on analysis of issues were the most effective training methods to teach critical thinking skills. The faculty, on average, considered almost all of the training methods listed in Figure 25 to be at least somewhat effective (i.e. a ranking of "5" on the effectiveness scale). Creating documents had the lowest rankings.

\section{Does the contracting workforce have the critical thinking skills to implement sound}

business decisions or are there gaps? The DAU contracting faculty survey had a question that assessed their confidence that the contracting workforce was able use critical thinking skills to implement sound business decisions. The responses to this question appear in Figure 26 and indicate that only a third of the DAU faculty members surveyed are confident that the contracting workforce has the ability to use critical thinking skills to make sound business decisions. 


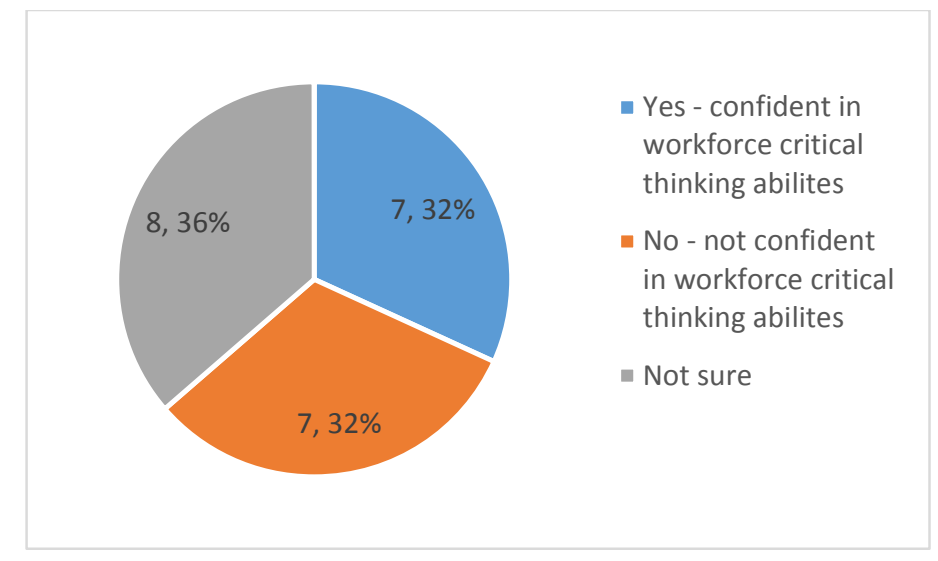

Figure 26. Confidence in workforce ability to use critical thinking (faculty) (Jones, 2016a).

The faculty participants provided comments on any noted specific skill gaps in their observations of students' use of critical thinking skills. Figure 27 summarizes data on instructor comments on observed "skill gaps" and other problem areas relating to critical thinking in the contracting workforce and provides the frequency that the issue was addressed. Note that out of the 22 responding faculty members, the comments received varied greatly, with some being very positive and others indicating room for improvement.

Due to the relatively low frequency (1 to 3 instances) of the reporting of any given issues noted below, the issues should not be considered “skill gaps” but possible areas for improvement until additional research confirms if any systemic gap exists. Also, Appendix F demographic data (at Figure 42) shows that $94 \%$ of the contracting workforce survey respondents had some type of college degree, suggesting that the anomalies may represent a low percentage of the contracting workforce.

DAU faculty offered several suggestions to improve the perceived problem areas indicated in Figure 27. One participant suggested that a reading comprehension test become standard in the hiring process for contract specialists. Another suggestion was to include a mini critical thinking block in a Level I and II course to educate students about critical thinking. 


\begin{tabular}{|c|c|}
\hline IMPROVEMENT AREAS & Frequency \\
\hline \multicolumn{2}{|l|}{ WORKPLACE CULTURE/ENVIRONMENT PROBLEMS } \\
\hline $\begin{array}{l}\text { Work environment does not promote critical thinking/empower workforce to } \\
\text { think critically }\end{array}$ & 3 \\
\hline Contracting leadership not practicing critical thinking in the workplace & 1 \\
\hline $\begin{array}{l}\text { On-the-job trainers are unqualified to train workforce due to poor reading } \\
\text { comprehension and critical thinking skills }\end{array}$ & 1 \\
\hline $\begin{array}{l}\text { Hiring practices/inadequate performance reviews allow unqualified } \\
\text { personnel to enter/remain in profession }\end{array}$ & 1 \\
\hline \multicolumn{2}{|l|}{ DAU CURRICULUM PROBLEMS } \\
\hline $\begin{array}{l}\text { DAU courses inconsistent in levels of difficulty and expectations to use } \\
\text { critical thinking skills }\end{array}$ & 1 \\
\hline $\begin{array}{l}\text { Importance of contracting professionalism not stressed enough in DAU } \\
\text { courses }\end{array}$ & 1 \\
\hline $\begin{array}{l}\text { Certification does not equate to competency - instructors pass unqualified } \\
\text { students }\end{array}$ & 1 \\
\hline \multicolumn{2}{|l|}{ WORKFORCE SKILL/MOTIVATION PROBLEMS } \\
\hline $\begin{array}{l}\text { Workforce has little desire to work difficult problems/apply critical thinking } \\
\text { skills }\end{array}$ & 2 \\
\hline $\begin{array}{l}\text { Reading comprehension level too low to understand the acquisition } \\
\text { regulations }\end{array}$ & 2 \\
\hline $\begin{array}{l}\text { Insufficient job experience/contracting knowledge to apply critical thinking } \\
\text { skills effectively }\end{array}$ & 2 \\
\hline Insufficient analysis skills to discern issues and $2^{\text {nd }} / 3^{\text {rd }}$ order effects & 1 \\
\hline Insufficient self-regulation skills to recognize own biases & 1 \\
\hline Cost accounting skills need improvement & 1 \\
\hline
\end{tabular}

Figure 27. Critical thinking areas for improvement (faculty) (Jones, 2016a).

Mandatory testing of the contracting workforce to measure core critical thinking skills and the disposition to use those skills was also suggested.

Have DAU course revisions resulted in improvements in critical thinking skills? The faculty survey posed two questions on critical thinking related revisions to the DAU contracting course curriculum. The first question requested that the participant indicate which courses had undergone major critical thinking revisions and the timeframe of those revisions in relation to the release of the three phases of Better Buying Power initiatives to date. The table in Figure 28 illustrates courses at each certification level with major critical thinking related revisions and the 
timing of the revisions.

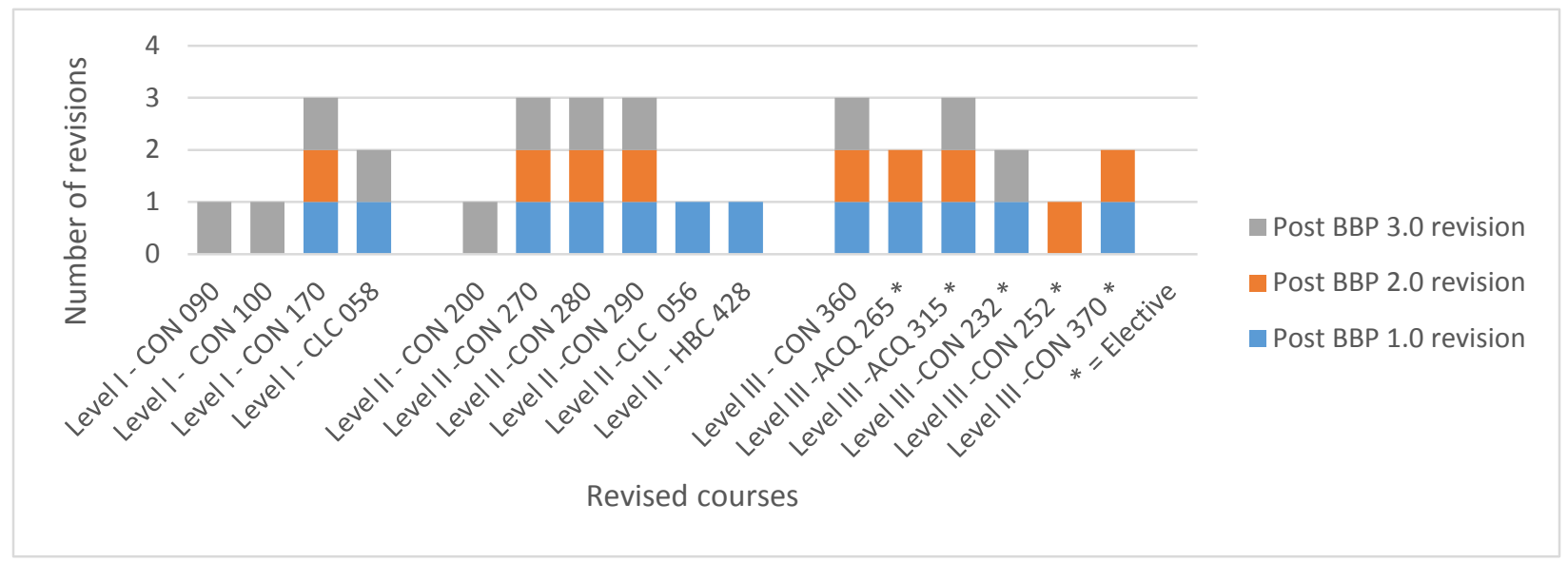

Figure 28. Critical thinking related course revisions (faculty) (Jones, 2016a).

The survey questioned if participants had generally observed an improvement in the contracting workforce's critical thinking skills as a result of the course revisions noted in Figure 28. Figure 29 illustrates that less than $25 \%$ of the faculty observed improvements to the contracting workforce's critical thinking skills as a result of critical thinking related course revisions.

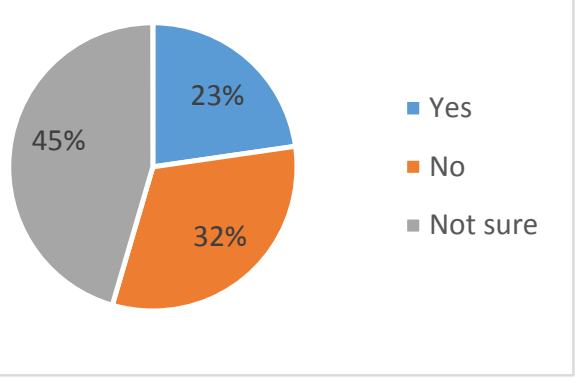

Figure 29. Critical thinking improvements related to course revisions (faculty) (Jones, 2016a).

Contracting faculty survey participants provided associated comments on this issue. Faculty members commented that CON 090, CON 170, and CON 360 all include critical thinking elements or instruction blocks on critical thinking. Faculty indicated that, although the specific term “critical thinking” is not always used in classes, contracting courses include 
opportunities for the use of critical thinking skills (such as analysis, interpretation, and quantitative defense of a position) in the class exercises, scenarios, and projects that are part of the course curriculum. Newer courses are developed with a critical thinking component. The Level III capstone course, CON 360, includes the demonstration of critical thinking skills in the grading rubric. One faculty member commented that while some students do gain an appreciation for what is required to analyze complex issues and devise solutions, an equal number of students do not.

An analysis of the survey data indicates that there did not appear to be any significant correlation of critical thinking related course revisions to the releases of the various BBP initiatives. For example, BBP 2.0 placed a greater emphasis on critical thinking skills being vital to making sound decisions, but no corresponding increase in course revisions after BBP 2.0 was supported by the study data. (Approximately a third of revisions occurred after each BBP release.) The data shows no significant correlation of faculty observations of improvements in critical thinking to course revisions.

Improvements in critical thinking training. Two open-ended faculty survey questions solicited written comments on potential improvements in critical thinking training from the DAU faculty respondents. Forty-five percent of the respondents thought there should be improvements or additions to the mandatory contracting curriculum to improve critical thinking skills in the workforce, while $27 \%$ of the faculty thought improvements or additions were not needed and another 27\% were not sure. Figure 30 includes summaries of comments on improvements for critical thinking training offered by the DAU faculty. Roughly half of the faculty respondents provided the suggested improvements listed in Figure 30. Each suggested improvement has a low frequency of occurrence (i.e. a frequency of 1 equates to $4.5 \%$ of 
respondents), therefore the suggestions are not meant to indicate the presence of any systemic issues or problems.

\begin{tabular}{|l|c|}
\hline FACULTY SUGGESTED IMPROVEMENTS & Frequency \\
\hline & \\
\hline STUDENT ACCOUNTABILITY \& READINESS & 2 \\
\hline $\begin{array}{l}\text { Assess students' basic skills (reading, math, writing, computer skills) prior to } \\
\text { their attendance in any certification courses }\end{array}$ & 1 \\
\hline $\begin{array}{l}\text { Consider an introductory course in critical thinking and the professional } \\
\text { assessment of critical thinking skills in students as a part of that course }\end{array}$ & \\
\hline & 2 \\
\hline DAU CURRICULUM \& OPERATIONAL CHANGES & 1 \\
\hline $\begin{array}{l}\text { Greater emphasis on individual critical thinking ability; less group projects so } \\
\text { individuals must be able to demonstrate their own critical thinking abilities }\end{array}$ & 1 \\
\hline $\begin{array}{l}\text { More essays to ensure students can analyze data and communicate results in } \\
\text { writing. }\end{array}$ & 1 \\
\hline Critical thinking skills included in all courses at all levels & \\
\hline $\begin{array}{l}\text { One early Level I, II, and III class should include a critical thinking module; all } \\
\text { subsequent courses include exercises where individual demonstration of critical } \\
\text { thinking skills is mandatory to earn course credit }\end{array}$ & 1 \\
\hline $\begin{array}{l}\text { Change instructor evaluation so that if a student doesn't comprehend course } \\
\text { material, instructor can fail the student without adverse effects on instructor's } \\
\text { MTMs }\end{array}$ & \\
\hline Make CLM 058 mandatory for either Level I or II certification when it is published & 1 \\
\hline
\end{tabular}

Figure 30. Faculty suggestions for critical thinking training improvements (faculty) (Jones, 2016a).

The DAU faculty survey questioned participants on whether a course similar to PMT 401 (DAU’s Program Manager's course) with case-based scenarios and simulations would be a useful addition to the contracting curriculum. Figure 31 illustrates the DAU faculty survey results on the addition of a case-based contracting course similar to PMT 401.

Figure 31. Case-based scenario \& simulations course addition (faculty) (Jones, 2016a). 
Faculty comments on the addition of a contracting course similar to PMT 401 to develop the contracting workforce’s critical thinking skills were solicited and are presented in Figure 32.

\begin{tabular}{|l|c|}
\hline COMMENTS ON ADDITION OF COURSE TO IMPROVE CRITICAL & Frequency \\
THINKING SKILLS & 4 \\
\hline $\begin{array}{l}\text { Suggest the addition or continued use of case-based scenarios and } \\
\text { simulations throughout curriculum; repetition throughout contracting } \\
\text { curriculum will promote critical thinking culture across DoD }\end{array}$ & 1 \\
\hline $\begin{array}{l}\text { Contracting has too many mandatory courses but an elective course focused } \\
\text { on contracting issues could be useful }\end{array}$ & 1 \\
\hline More focus on professionalism & 1 \\
\hline Additional contracting leadership courses are needed & 3 \\
\hline Some of the instructors need additional critical thinking skills & 1 \\
\hline $\begin{array}{l}\text { There are real benefits to DoD acquisition programs when PMs and } \\
\text { Contracting Officers with strong critical thinking skills team }\end{array}$ & 1 \\
\hline Liked idea of a separate contracting course if it was shorter that PMT 401 & 1 \\
\hline Not needed - CON 360 and CON 280 are sufficient & \\
\hline
\end{tabular}

Figure 32. Comments on case-based scenario course (faculty) (Jones, 2016a).

Further research areas related to critical thinking training. The final faculty survey question solicited input on additional topics related to critical thinking skills training requiring further research. The faculty respondents indicated that further study was warranted to

- determine the level of critical thinking training and capability of DAU instructors;

- discover the most effective teaching methods for pricing concepts;

- effectively teach critical thinking to adults;

- $\quad$ teach interest-based negotiations;

- $\quad$ explore Program Manger interests and decision making;

- $\quad$ craft creative acquisition strategies; and

- explore the extent contracting professionals think critical thinking is welcome in their workplace. 


\section{Contracting Curriculum Analysis}

An analysis of the current contracting courses is provided to determine the level of critical thinking training taking place in the mandatory contracting curriculum. Figure 33 provides a summary of the analysis. The analysis included

- a review of contracting course descriptions and objectives to determine whether critical thinking or associated skills were included in the curriculum;

- whether or not the course was offered in a resident class or some form of distance learning;

- the DAU contracting faculty’s survey input- including the average ranking of critical thinking for the course;

- specific comments on the course indicating critical thinking was part of the curriculum, and

- whether the course was revised to improve critical thinking elements in the course. The green and blue blocks on Figure 33 provide positive indicators of critical thinking being included in a course or that critical thinking in that course is at least somewhat effective. An "R" (for resident class) in the first column is coded green since survey data indicates the workforce members responded that resident classes were more effective than distance learning courses. (Figure 7 indicates that 5.5 times as many workforce members responded that resident courses increased the effectiveness of critical thinking training over the number of workforce members indicating distance learning courses were effective.) The second column indicates that most of the course descriptions or objectives refer to critical thinking or to critical thinking related skills as being included in the course, and are also coded green. 


\begin{tabular}{|c|c|c|c|c|c|}
\hline Course number and name & \begin{tabular}{|c|} 
Distance \\
Learning \\
(DL), \\
Continuous \\
Learning \\
(CL), or \\
Resident \\
(R) \\
course? \\
\end{tabular} & $\begin{array}{c}\text { iCatalog } \\
\text { description (D) } \\
\text { and/or course } \\
\text { objectives (O) } \\
\text { includes } \\
\text { reference to } \\
\text { critical thinking } \\
\text { or critical } \\
\text { thinking gkills }\end{array}$ & $\begin{array}{l}\text { DAU Faculty } \\
\text { average } \\
\text { ranking of } \\
\text { critical } \\
\text { thinking } \\
\text { training for } \\
\text { course }\end{array}$ & $\begin{array}{l}\text { DAU Faculty } \\
\text { comments } \\
\text { specifically } \\
\text { indicated that } \\
\text { the course } \\
\text { teaches/uges } \\
\text { critical } \\
\text { thinking skills }\end{array}$ & $\begin{array}{l}\text { DAU Faculty } \\
\text { indicated } \\
\text { course had at } \\
\text { least one major } \\
\text { revision since } \\
\text { BBP } 1.0 \text { to } \\
\text { improve } \\
\text { critical } \\
\text { thinking gkills }\end{array}$ \\
\hline \multicolumn{6}{|l|}{ LEVEL I COURSES } \\
\hline $\begin{array}{l}\text { CON 090-Federal Acquisition Regulation } \\
\text { Fundamentals }\end{array}$ & $\mathrm{R}$ & Yes - D & 4.8 & Yes & Yes \\
\hline CON 100-Shaping Smart Business Arrangements & $\mathrm{DL}$ & Yes - D & 3.0 & & Yes \\
\hline CON 121-Contract Planning & $\mathrm{DL}$ & Yes - O & 3.8 & & \\
\hline CON 124-Contract Execution & $\mathrm{DL}$ & Yes - D & 4.0 & & \\
\hline CON 127-Contract Management & $\mathrm{DL}$ & Yes - D & 3.8 & & \\
\hline $\begin{array}{l}\text { CON 170-Fundamentals of Cost and Price } \\
\text { Analygis }\end{array}$ & $\mathrm{R}$ & Yes - D & 4.4 & Yes & Yes \\
\hline $\begin{array}{l}\text { CLC 025-Small Business Program for } \\
\text { Contracting Officers }\end{array}$ & $\mathrm{CL}$ & Not stated & 5.0 & & \\
\hline $\begin{array}{l}\text { CLC 033-Contract Format and Structure for DoD } \\
\text { e-Buginess Environment }\end{array}$ & $\mathrm{CL}$ & Not stated & 5.0 & & \\
\hline $\begin{array}{l}\text { CLC 057-Performance Based Payments and } \\
\text { Value of Cash Flow }\end{array}$ & $\mathrm{CL}$ & Yes - D & 4.0 & & \\
\hline CLC 058-Introduction to Contract Pricing & $\mathrm{CL}$ & Yes - D & 3.8 & & Yes \\
\hline \multicolumn{6}{|l|}{ LEVEL II COURSES } \\
\hline CON 200-Business Decigions for Contracting & $\mathrm{DL}$ & Yes-D & 4.0 & & Yes \\
\hline CON 216-Legal Considerations in Contracting & $\mathrm{DL}$ & Yes-O & 5.0 & & \\
\hline CON 270-Intermediate Cost and Price Analygis & $\mathrm{R}$ & Yes - D & 5.2 & & Yes \\
\hline $\begin{array}{l}\text { CON } 280 \text {-Source Selection and Administration of } \\
\text { Service Contracts }\end{array}$ & $\mathrm{R}$ & Yes - D & 4.7 & Yes & Yes \\
\hline $\begin{array}{l}\text { CON 290-Contract Administration and } \\
\text { Negotiation Techniques in a Supply Environment }\end{array}$ & $\mathrm{R}$ & Yes - D & 6.2 & Yes & Yes \\
\hline $\begin{array}{l}\text { CLC 051-Managing Govemment Property in the } \\
\text { Possession of Contractors }\end{array}$ & $\mathrm{CL}$ & Not stated & 6.0 & & \\
\hline CLC 056-Analyzing Contract Costs & $\mathrm{CL}$ & Yes - D & 4.0 & & Yes \\
\hline HBS 428-Negotiating & $\mathrm{CL}$ & Yes - D & 4.5 & & Yes \\
\hline \multicolumn{6}{|l|}{ LEVEL III COURSES } \\
\hline CON 360-Contracting for Decision Makers & $\mathrm{R}$ & Yes - D & 5.8 & Yes & Yes \\
\hline $\begin{array}{l}\text { Elective - ACQ 265-Mission-Focused Services } \\
\text { Acquigition }\end{array}$ & $\mathrm{R}$ & Yes - D & 5.2 & & Yes \\
\hline $\begin{array}{l}\text { Elective - ACQ 315-Understanding Industry } \\
\text { (Business Acumen) }\end{array}$ & $\mathrm{R}$ & Yes - D & 6.0 & & Yes \\
\hline Elective - ACQ 370-Acquigition Law & $\mathrm{R}$ & Yes - D & & & \\
\hline $\begin{array}{l}\text { Elective - CON 232-Overhead Management of } \\
\text { Defense Contracts }\end{array}$ & $\mathrm{R}$ & Yes - D & 5.5 & Yes & Yes \\
\hline Elective - CON 244-Construction Contracting & $\mathrm{R}$ & Yes - D & 5.0 & & \\
\hline $\begin{array}{l}\text { Elective - CON 252-Fundamentals of Cost } \\
\text { Accounting Standards }\end{array}$ & $\mathrm{R}$ & Yes - D & 5.5 & & Yes \\
\hline $\begin{array}{l}\text { Elective - CON 334-Advanced Contingency } \\
\text { Contracting Officer's Course }\end{array}$ & $\mathrm{R}$ & Yes - D & 5.0 & & \\
\hline Elective - CON 370-Advanced Contract Pricing & $\mathrm{R}$ & Yes - D & 6.5 & & Yes \\
\hline Course rankings: & \begin{tabular}{|c|}
$3.0-3.9$ \\
Somewhat \\
ineffective
\end{tabular} & $\begin{array}{c}4.0-4.9 \\
\text { Neither effective } \\
\text { nor ineffective }\end{array}$ & $\begin{array}{l}5.0-5.9 \\
\text { Somwhat } \\
\text { effective }\end{array}$ & $\begin{array}{r}6.0-6.9 \\
\text { Effective }\end{array}$ & \\
\hline
\end{tabular}

Figure 33. Critical thinking in CON curriculum (Defense Acquisition University, 2015b; Jones, 2016a).

The faculty course ranking codes (in the third column) indicate that two Level I courses, four Level II courses, and most Level III courses were either somewhat effective or effective in using critical thinking in contracting curricula training. Faculty comments indicated that several 
courses (CON 090, 170, 280, 290, 360, and 232) included critical thinking elements and are coded green in the fourth column. Finally, faculty reported that several courses have been revised to improve the critical thinking in their coursework as indicated in the last column of Figure 33. This analysis of data supports that as the contracting curriculum progresses through the contracting certification levels, more critical thinking is included in the courses. The analysis indicates that critical thinking training becomes more effective as the certification level increases.

\section{Discussion/Interpretation of Survey Results}

Data was analyzed from each survey to answer questions that related to the research question, "Does the current required Defense Acquisition Workforce Improvement Act contracting training address the training of critical thinking skills sufficient to implement Better Buying Power initiatives?” Potential associations between responses in the data of similar questions were reviewed to determine if student and faculty responses were correlated in the two surveys.

Critical thinking training effectiveness. The workforce survey data indicates that the workforce perceives the most effective training to be on-the-job contracting work experience, followed closely by self-taught methods, other on-the-job work experience, and formal education courses. The workforce ranked DAU contracting courses (at all levels) as slightly less effective than the average ranking of the other training methods. DAU courses were ranked at an average of 5.2 (on a 7-point scale) as compared to an average ranking of 5.4 for a variety of critical thinking training methods (as illustrated in Figure 6).

In Figure 23, the faculty ranking of the effectiveness of critical thinking training in DAU contracting courses is shown by level and with a progression of effectiveness trending up with 
increasing certification levels. The faculty ranked the effectiveness of critical thinking training in DAU Level I contracting courses as being 4.1, Level II contracting courses as being 4.9, and Level III contracting courses as being 5.6 on a 7 point scale. The faculty ranked the effectiveness of the critical thinking training in DAU courses slightly higher than did the workforce. The increased curriculum effectiveness ratings seen during the progression from Level I to Level III may be due to Level I classes being largely distance learning classes and the teaching of fundamental contracting concepts in the earlier Level I classes. Conversely, Level III classes are largely resident courses with a focus on scenario-based, hands-on learning. The type of class and an increased focus on teaching fundamental concepts could decrease the perceived effectiveness of the lower level class curriculums.

Most effective training methods. The workforce and DAU faculty members each ranked a list of various teaching methods from the most to least effective method. Three of the top four most effective training methods and the three least effective methods were the same in the lists. The workforce participants’ comments stressed resident training and on-the-job training whereas the DAU faculty offered that properly facilitated classroom discussion could be valuable as a critical thinking training method. Figure 34 lists the most to least effective training

\begin{tabular}{|l|l|}
\hline Workforce ranking (derived from Figure 10) & Faculty ranking (derived from Figure 25) \\
\hline 1. Analysis of scenarios & 1. Analysis of scenarios \\
\hline 2. Hands-on analysis of issues & 2. Case studies \\
\hline 3. Exercises & 3. Hands-on analysis of issues \\
\hline 4. Case studies & 4. Resolving issues \\
\hline 5. Simulations & 5. Doing a critical thinking project \\
\hline 6. Resolving issues & 6. Exercises \\
\hline 7. Doing a critical thinking project & 7. Simulations \\
\hline 8. Interpretation of policy/issues & 8. Interpretation of policy/issues \\
\hline 9. Learning to apply quantitative tools & 9. Learning to apply quantitative tools \\
\hline 10. Creating documents & 10. Creating documents \\
\hline $\begin{array}{l}\text { Other - resident courses, on-the-job training, } \\
\text { cross training in other functional areas }\end{array}$ & $\begin{array}{l}\text { Other - properly facilitated classroom } \\
\text { discussions }\end{array}$ \\
\hline
\end{tabular}

Figure 34. Comparison of training methods effectiveness rankings (Jones, 2016a, 2016b). 
methods as perceived by the workforce and faculty.

Methods to improve training effectiveness. The workforce and faculty surveys had questions pertaining to ways critical thinking training could be improved. The analysis of the workforce response data (as depicted in Figure 7) indicates that hands-on exercises, using more case-based and simulation training, and more interaction and discussion in the classroom are the methods the workforce believes would increase critical thinking training effectiveness.

Several workforce respondents commented that a course using case-based hands-on training (such as the Harvard business case method) was effective in teaching critical thinking skills. Other workforce members offered that training with workplace teammates, well facilitated classroom discussions, and teaching critical thinking skills on-the-job would all be effective ways to teach these skills. A suggestion was made to use more operational contracting examples in DAU course work instead of the focus being primarily on systems contracting, which does not apply to some segments of the contracting workforce.

The faculty responses suggested changes in two main areas to improve critical thinking: (1) student readiness and (2) changes to DAU curriculum and operating procedures. Several faculty members commented that students should be assessed on basic reading, writing, math, and computer skills prior to attendance in any certification courses. One faculty comment indicated that some students are unable to read and comprehend the FAR and that a reading comprehension test should be part of the hiring process. Another faculty participant suggested including a professional assessment of critical thinking skills as a part of introductory critical thinking course.

The faculty participants made several suggestions for changes in DAU curriculum and operations to improve critical thinking. A greater emphasis on individual critical thinking was 
cited by several faculty members as a method to improve critical thinking. Fewer group projects, mandatory demonstration of individual critical thinking abilities to earn course credit, and the use of more individual essays that required both data analysis and written communication of analysis results were all cited as ways to achieve higher levels of individual critical thinking. Ideas regarding the best method to introduce critical thinking ranged from teaching a block on critical thinking in an early course at each certification level to including critical thinking in all courses at all certification levels.

One faculty member indicated that a continuous learning module (CLM 058) on critical thinking is currently under development and suggested the CLM be mandatory for Level I or II certification when it is released. Figure 35 provides the draft course description for CLM 058. A DAU course developer (personal communication, 11 February 2016) indicated that CLM 058 will include an interactive activity to improve critical thinking skills in the acquisition workforce.

This module introduces the student to Critical Thinking (CT) skills and the application of those skills in the daily decision making required of today's acquisition professional. This module discusses the sometimes incomplete and often complex information available to acquisition managers and identifies methods to ask the right questions, to recognize strong versus weak arguments, and to be aware of how much information is needed to reach a logical conclusion and to make decisions important to the success of the organization. Students will be introduced to good CT practices and provided references to reflect on their critical thinking skills while creating good habits utilized to process information, solve problems, and achieve positive outcomes.

Figure 35. CLM 058 draft course description (Defense Acquisition University, 2015b).

Several faculty comments indicated that DAU should change the instructor performance evaluations. Comments indicated that failing a student that does not comprehend the course material could result in bad "metrics that matter” (or MTM) scores. Faculty participants indicated that bad MTM scores can result in adverse instructor performance evaluations. 
Critical thinking assessments. The workforce survey had a question regarding experiences with critical thinking skills assessments. The faculty expressed opinions about assessing critical thinking skills in survey comments. Twenty-four percent of the contracting workforce had taken an assessment of their critical thinking skills. Only 14\% of the workforce had been assessed on their disposition to apply critical thinking skills. Of those assessed, most were assessed as part of a class or by using an on-line or automated assessment tool. Even though a relatively small amount of the workforce had taken skills and disposition assessments, of those that had been tested, only $4 \%$ thought the results were inaccurate.

Faculty members suggested two different methods of assessing critical thinking skills. One faculty member suggested that students should take both the Business Critical Thinking Skills Test and the California Critical Thinking Dispositions Inventory Test to baseline their skill level and their likelihood to solve problems using their critical thinking skills. Another faculty member suggested bringing in a professional critical thinking expert to lead a dedicated critical thinking class that included a critical thinking assessment.

Importance of critical thinking skills. The contracting workforce survey data indicates that the workforce, on average, believes that critical thinking skills are important to make sound business decisions or understand complex contracting issues. Of the six critical thinking skills (interpretation, analysis, inference, evaluation, explanation, and self-regulation- all defined in Figure 2), the workforce collectively ranked analysis as the most important of the skills for making complex decisions, followed closely by evaluation, interpretation, and explanation. These skills were ranked between "important” and “very important”. Self-regulation and inference skills were viewed as being slightly less important, but were still ranked as being between "somewhat important” and “important”. 
Is the workforce using their critical thinking skills? When faculty members responded to the survey question regarding the extent they observed the six core critical thinking skills being exhibited in contracting classes, the response data indicated that more critical thinking skills were exhibited in level III classes than in Level I and II classes. With the exception of evaluation and interpretation skills (which were observed slightly more frequently in Level I classes than in Level II classes), the level of faculty observations of each critical thinking skill increased as students progressed through the certification levels. Students were observed to exhibit slightly higher than average critical thinking skills overall during the Level III certification courses.

The workforce data indicates the workforce used critical thinking skills for Better Buying Power tasks, on average, more than "sometimes” but less often than "frequently". The data shows that some tasks that involve a greater percentage of the contracting workforce (such as using appropriate contract types, using market research effectively, improving requirements definitions for services, streamlining efforts, and creating competitive contracting environments) frequently entail greater use of critical thinking skills by the workforce. The data also indicates there is room for improvement in the use of critical thinking skills, particularly in some of the less frequently performed tasks (such as promoting modular systems architecture in systems, increasing the use of incentive type contracts, and increasing the use of Small Businesses in Research and Development (R\&D)). Study data (at Figure 18) shows that contracting workforce participants reported they did not routinely use critical thinking skills for these less-performed BBP tasks and, at best, “sometimes used” critical thinking skills for these tasks.

BBP and critical thinking skills. The data on the DAU faculty's confidence that the workforce has adequate critical thinking skills to implement sound business decisions required 
by BBP initiatives revealed only one-third of the faculty (32\%) indicted confidence that the contracting workforce was able use critical thinking skills to implement sound business decisions. Another one-third of the faculty (36\%) was not sure of the workforce's critical thinking abilities. The remaining third (32\%) of the faculty indicated they were not confident in the contracting workforce's critical thinking abilities.

Several faculty comments suggested potential problems they had observed with the workforce that could impact the contracting workforce's ability to develop critical thinking skills. Several faculty survey respondents reported the perception that not all contracting workplaces and leadership supported critical thinking or empowered critical thinkers. One faculty respondent indicated that students had reported being told not to ask questions and "to just make it look like this” in their workplace (Jones, 2016a).

A different problem cited by several faculty participants was poor reading comprehension levels in contracting workforce students, which results in student difficulties in interpreting acquisition regulations. One faculty member asserted that $25 \%$ of the students' reading comprehension level was below the level required to comprehend the FAR and that another 25\% of students were marginally proficient or lacked the motivation to further develop their critical thinking skills. The comment was supported by other comments regarding students having little desire to work difficult problems in class that required the application of critical thinking skills.

Several faculty respondents commented that a better assessment of individuals making up the Acquisition Corps was needed, either prior to hiring or prior to attendance in certification classes. One faculty member offered that passing a basic skills test (covering reading, math, and basic computer skills) should be part of DAU pre-course work, with mandatory remedial training 
required for those not passing a basic skills test. The following section provides a study conclusion and recommendations.

\section{Chapter 5 - Conclusion and Recommendations}

\section{Conclusion}

The current required DAWIA contracting training curriculum includes sufficient training in critical thinking skills for members of the workforce to implement Better Buying Power initiatives. By the time a contracting professional is Level III certified, the research data on the contracting course content indicates the contracting workforce has been exposed to critical thinking concepts, skills, and reinforcing classroom activities in many of the contracting courses. The research data indicates (in Figure 23) that DAU faculty respondents ranked the use of critical thinking within the contracting curriculum in Level III classes, on average, as being a 5.6 on a 7-point scale- between "somewhat effective” or "effective.” As DAU revises and updates courses, more courses (particularly at the higher certification levels) have critical thinking elements added. DAU is in the process of adding an interactive continuous learning module on critical thinking.

On average, the contracting workforce perceived critical thinking skills as being important to their profession and reported using critical thinking skills in the performance of their jobs. Faculty respondents reported that contracting workforce members exhibited between “average” and "above average” rankings for each of the six critical thinking skills by the time they were attending Level III certification classes, as indicated in Figure 24. Faculty comments indicated that some members of the workforce exhibited high levels of critical thinking.

There is, however, room for improvement of the critical thinking skills of the Army contracting workforce. The faculty research data reveals that only a third of the DAU faculty 
respondents were confident that the contracting workforce had adequate critical thinking skills to implement sound business decisions. (Note that the faculty data on the assessment of adequate critical thinking skills is extrapolated to the Army contracting workforce in this instance since DAU classes are comprised of students from all DoD services.) The recommendations below address some of the ideas for improving critical thinking skills in the workforce.

\section{Recommendations}

The research and survey data provided information on ways to increase the effectiveness of teaching critical thinking skills and increase the level of critical thinking in the contracting workforce.

Recommendation 1. DAU's mandatory contracting curriculum courses should use more hands-on exercises, case-based and simulation training, and more interaction, discussion, and Socratic questioning in resident classes to effectively teach critical thinking skills to contracting personnel. Contracting workforce participants ranked the effectiveness of DAU training to be slightly less effective than other critical thinking training methods. One reason for the perception could be the higher concentration of distance learning classes for Level I classes.

There appears to be consensus among workforce members, DAU faculty, professional educators (as cited in chapter 1), and senior acquisition executives that more on-the-job training, real-life case studies and simulations of real-life situations were all desirable additions to acquisition workforce training. A relatively short resident class using hands-on training methods and contracting and business examples could benefit the contracting workforce and emphasize the importance of critical thinking in the contracting workplace.

Recommendation 2. DAU should stress individual critical thinking work in DAU courses. The individual application of critical thinking skills to evaluate, interpret, and analyze 
data in hands-on exercises and then explain a course of action in writing would improve vital contracting skills. Individual classroom assignments would give DAU faculty the ability to hold students individually accountable for performance and could assist faculty in identifying struggling students.

Recommendation 3. DAU should review the faculty evaluation policy to ensure there are no disincentives for faculty members that fail students not able to demonstrate a mastery of the course material. DAU should ensure that the revised policies are communicated to the DAU faculty.

Recommendation 4. DAU should conduct further research on increasing the effectiveness of critical thinking training for the entire acquisition workforce. Related topics for further research include: (1) determining the level of critical thinking training and capability of DAU instructors; (2) how to effectively teach critical thinking to adults; and (3) the extent contracting professionals think critical thinking is welcome in the workplace. Consider conducting any future research at the DoD level using random samples to increase the reliability of the study.

Recommendation 5. The Office of Personnel Management should consider mandating assessments of critical thinking skills in the hiring process for 1102 series employees. Automated tests are available for measuring critical thinking skills and disposition to use critical thinking skills through various organizations that promote critical thinking. Requiring minimum levels of critical thinking skills as a requirement for entry into the career field would improve the critical thinking abilities of the DoD contracting workforce.

Recommendation 6. If recommendation 5 is not plausible, DoD should mandate the assessment of a mandatory minimum level of scholastic abilities in reading comprehension, 
writing, mathematics, and computer skills before contracting professionals begin Level I certification courses. An early assessment of the contracting workforce would identify new workforce members requiring additional work to obtain remedial training during the early (i.e. career conditional) phase of the member's career. Personnel transferring into the contracting career field should also be assessed for basic skills prior to taking Level I contracting courses to increase the probability of later success in the contracting career field.

Recommendation 7. Contracting organizations should consider assessing the critical thinking skills of Contracting Officers prior to issuing them Contracting Officer warrants or prior to critical assignments.

Recommendation 8. Contracting organizations should promote critical thinking in the contracting workplace environment. According to the survey data (see Figure 6), improving critical thinking skills could be accomplished by instituting formal mentoring and coaching programs. Ensuring qualified trainers stress critical thinking skills in on-the-job work experiences should also prove to be effective training means.

Recommendation 9. Contracting organizations should ensure that the certified Level III contracting workforce is aware of training opportunities to enhance critical thinking skills. DAU offers many continuous learning modules that can help sharpen analysis, evaluation, and explanation skills. CLM 058 will be devoted to Critical Thinking when it is released. Contracting courses with critical thinking elements are noted in Figure 33. Several Harvard Business School courses such as HBS 409-Decision Making, HBS 402- Business Case Development, and HBS 421-Innovation and Creativity also incorporate critical thinking skills. 


\section{Summary}

The research shows that the current required DAWIA contracting training does adequately address the training of critical thinking skills in the contracting curriculum. DAU is revising and creating courses with a focus on critical thinking, and encouraging students to use critical thinking through active participation in classroom exercises, simulations, case studies, and other activities. Furthermore, the data indicates workforce appreciation of the importance of critical thinking skills in the contracting profession. DoD’s Better Buying Power initiatives demand a high level of critical thinking skills to ensure sound decision-making. The research indicates there is still room for improvement in honing the workforce’s critical thinking skills. 


\section{References}

Assad, S. D. (2011, March 25). Upcoming Changes to the Contracting Curriculum in Fiscal Year 2012. Washington, D.C.

Carter, A. B. (2010, June 28). Better Buying Power: Mandate for Restoring Affordability and Productivity in Defense Spending. Washington, D.C.

Churchill, W. (n.d). Quotes and aphorisms. Retrieved from at http://quotecitation.com/en/life/840

Defense Acquisition University. (2000). Business Plan 2001: Smart Business 20/20. Retrieved from http://www.dau.mil/AboutDAU/DAU_History/Documents/SB2020.pdf.

Defense Acquisition University. (2001). FY 2002 Amended Budget Submission. Retrieved from http://comptroller.defense.gov/Portals/45/Documents/defbudget/fy2002/budget_justificati on/pdfs/01_Operation_and_Maintenance/fy02pb_dau.pdf

Defense Acquisition University. (2015, December 31). Certification \& Core Plus Development Guides. Retrieved from Defense Acquisition University http://icatalog.dau.mil/onlinecatalog/CareerLvl.aspx?lvl=1\&cfld=3, http://icatalog.dau.mil/onlinecatalog/CareerLvl.aspx?lvl=2\&cfld=3, and http://icatalog.dau.mil/onlinecatalog/CareerLvl.aspx?lvl=3\&cfld=3.

Defense Acquisition University. (2015, May 16). Content TLO/ELOs for Critical Thinking. Defense Acquisition University. (2016, February 25). Department of Defense Better Buying Power. Retrieved from http://bbp.dau.mil/.

Defense Acquisition Workforce Improvement Act, 10 U.S.C. § 87 (1990).

Department of Defense. (1995). DoD Manual 5000.52-M, Career Development Program for Acquisition Personnel. Washington, D.C. 
Department of Defense. (2015). United States Department of Defense Fiscal Year 2016 Budget Request Overview, February 2015. Office of the Under Secretary of Defense (Comptroller) Chief Financial Officer. Retrieved from http://comptroller.defense.gov/Portals/45/documents/defbudget/fy2016/fy2016_Budget_ Request_Overview_Book.pdf

Facione, P.A. (1990). Critical Thinking: A Statement of Expert Consensus for Purposes of Educational Assessment and Instruction-Executive Summary “The Delphi Report”. Retrieved from www.insightassessment.com.

Facione, P.A. (2015). 2015 Update on the Critical Thinking Mindset from Delphi Report Principle Investigator, Dr. Peter Facione. Retrieved from www.insightassessment.com.

Facione, P.A. (2015). Critical Thinking: What It is and Why It Counts. Measured Reasons LLC, Hermosa Beach, CA. Retrieved from www.insightassessment.com.

Federal Procurement Data System-Next Generation. (2015). Retrieved from https://www.fpds.gov by ACC Business Analysis Division on 10 December 2015.

Fowler, B. (1996). Critical thinking across the curriculum project. Critical thinking definitions, 5. Retrieved from http://isites.harvard.edu/fs/docs/icb.topic204027.files/Critical_thinking_definitions.pdf

Garvin, D. A. (2003). HBS Cases: Developing the Courage to Act. Harvard Business School Working Knowledge. Retrieved from http://hbswk.hbs.edu/item/hbs-cases-developingthe-courage-to-act.

Insight Assessment. (2016) Retrieved from http://www.insightassessment.com.

Jones, C. L. (2016). [Critical Thinking Training Survey - Contracting Faculty]. Unpublished raw data. 
Jones, C. L. (2016). [Critical Thinking Training Survey - Contracting Workforce ]. Unpublished raw data.

Kendall, F. M. (2012, November 13). Better Buying Power 2.0: Continuing the Pursuit for Greater Efficiency and Productivity in Defense Spending. Washington, D.C.

Kendall, F. M. (2014, September 19). Better Buying Power 3.0 Presentation. Retrieved from http://csis.org/files/attachments/140919_BBP_3_0_Frank_Kendall_presentation.pdf

Kendall, F. M. (2015, April 9). Implementation Directive for Better Buying Power 3.0 Achieving Dominant Capabilities through Technical Excellence and Innovation. Washington, D.C.

King, A. (1995). Inquiring minds really do want to know: Using questioning to teach critical thinking. Teaching of Psychology, Vol 22(1), Feb 1995, 13-16. Retrieved from http://bama.ua.edu/ sprentic/695\%20King\%201995.pdf

Layton, E. (2007). The Defense Acquisition University: Training Professionals for the Acquisition Workforce 1992 - 2003. Fort Belvoir, Virginia: Defense Acquisition University Press. Retrieved from http://www.dau.mil/AboutDAU/AboutDocs/DAU\%20History\%20Book.pdf

Mauffette-Leenders, L. A., Erskine, J. A., \& Leenders, M. R. (2014). Learning with cases. London, Ontario, Canada: Ivey Publishing.

Professional Services Council \& Grant Thornton LLP. (2015). A closing window: Are we missing the opportunity for change? Retrieved from https://www.pscouncil.org/Downloads/documents/2014\%20PSC\%20Survey_11182015\% 20(002).pdf 
Stat Trek. (2016, March 16). Statistics and Probability Dictionary. Retrieved from http://stattrek.com/statistics/dictionary.aspx?definition=Non-probability\%20sampling and http://stattrek.com/statistics/dictionary.aspx?definition=Voluntary\%20sample

Testimony Before the House Committee on Armed Services: Witness Statement of HON Frank Kendall, Under Secretary of Defense Acquisition, Technology \& Logistics, July 10, 2014, $113^{\text {th }}$ Congress, Second Session. 3 (2014).

Willingham, D. T. (2007). Critical thinking: Why is it so hard to teach? American Educator, Summer 2007, 10 -11. Retrieved from https://www.uvm.edu/ facsen/generaleducation/Critical\%20Thinking\%20Article\%20\%20Willingham.pdf 


\section{Glossary of Acronyms}

Acronym

ACC

ACQ

BBP

CES

CLC

CLM

CON

CT

DA

DACM

DAU

DAWIA

DL

DoD

DPAP

ECC

FAR

FY

HASC

HBS

HQ

LN

MICC

MOS

MTMs

OPSEC

PMT

$\mathrm{R}$

$\mathrm{R} \& \mathrm{D}$

SSCF

TDA

USD(AT\&L)
Description

U.S. Army Contracting Command

Acquisition

Better Buying Power

Civilian Education System

Continuous Learning Course

Continuous Learning Module

Contracting

Critical Thinking

U.S. Department of the Army

Director of Acquisition Career Management

Defense Acquisition University

Defense Acquisition Workforce Improvement Act

Distance Learning

U.S. Department of Defense

Defense Procurement Acquisition Policy

U.S. Army Expeditionary Contracting Command

Federal Acquisition Regulation

Fiscal Year

House Committee on Armed Services

Harvard Business School

Headquarters

Local National

U.S. Army Mission \& Installation Contracting Command

Military Occupational Specialty

Metrics that Matter

Operations Security

Program Management

Resident

Research and Development

Senior Service College Fellowship

Table of Distribution and Allowances

Under Secretary of Defense for Acquisition, Technology, and Logistics 


\section{Appendix A - Better Buying Power Summary}

Under Secretary of Defense for Acquisition, Technology, and Logistics, the Honorable Frank

Kendall, used the following three presentation charts to introduce Better Buying Power 3.0 to the

Defense Acquisition Workforce on 19 September 2014. The charts were subsequently

distributed to the Defense Acquisition Workforce and summarize the Better Buying Power issues

(Kendall, 2014).

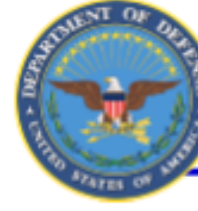

Achieve Affordable Programs

- Mandate affordability as a requirement

- Institute a system of investment planning to derive affordability caps

- Enforce affordability caps

Control Costs Throughout the Product Lifecycle

- Implement "should cost" based management

- Eliminate redundancy within warfighter portfolios

- Institute a system to measure the cost performance of programs and institutions and to assess the effectiveness of acquisition policies

- Build stronger partnerships with the requirements community to control costs

- Increase the incorporation of defense exportability features in initial designs

Incentivize Productivity \& Innovation in Industry and Government

- Align profitability more tightly with Department goals

- Employ appropriate contract types

- Increase use of Fixed Price Incentive contracts in Low Rate Initial Production

- Better define value in "best value" competitions

- When Lowest Price Technically Acceptable is used, define

Technically Acceptable to ensure needed quality

- Institute a superior supplier incentive program

- Increase effective use of Performance-Based Logistics

- Reduce backlog of DCAA Audits without compromising effectiveness

- Expand programs to leverage industry's IR\&D

Eliminate Unproductive Processes and Bureaucracy

- Reduce frequency of higher headquarters level reviews

- Re-emphasize AE, PEO and PM responsibility, authority, and accountability

- Reduce cycle times while ensuring sound investment decisions
Promote Effective Competition

- Emphasize competition strategies and create and maintain competitive environments

- Enforce open system architectures and effectively manage technical data rights

- Increase small business roles and opportunities

- Use the Technology Development phase for true risk reduction

Improve Tradecraft in Acquisition of Services

- Assign senior managers for acquisition of services

- Measure productivity using the uniformed services market segmentation

- Improve requirements definition/prevent requirements creep

- Increase small business participation, including through more effective use of market research

- Strengthen contract management outside the normal acquisition chain - installations, etc.

- Expand use of requirements review boards and tripwires

Improve the Professionalism of the Total Acquisition Workforce

- Establish higher standards for key leadership positions

- Establish increased professional qualification requirements for all acquisition specialties

- Increase the recognition of excellence in acquisition management

- Continue to increase the cost consciousness of the acquisition workforce - change the culture

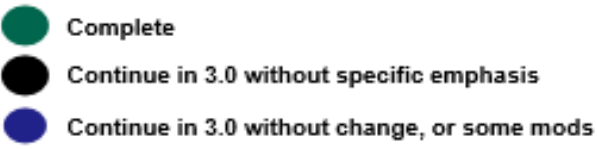

For additional information: http://bbp.dau.mil 


\section{B. Better Buying Power 3.0 DRAFT}

Achieving Dominant Capabilities through Technical Excellence and Innovation

Achieve Affordable Programs

- Continue to set and enforce affordability caps

Achieve Dominant Capabilities While Controlling Lifecycle Costs

- Strengthen and expand "should cost" based cost management

- Build stronger partnerships between the acquisition, requirements, and intelligence communities

- Anticipate and plan for responsive and emerging threats

- Institutionalize stronger DoD level Long Range R\&D Planning

Incentivize Productivity in Industry and Government

- Align profitability more tightly with Department goals

- Employ appropriate contract types, but increase the use of incentive type contracts

- Expand the superior supplier incentive program across DoD

- Increase effective use of Performance-Based Logistics

- Remove barriers to commercial technology utilization

- Improve the return on investment in DoD laboratories

Increase the productivity of IRAD and CR\&D

Incentivize Innovation in Industry and Government

- Increase the use of prototyping and experimentation

- Emphasize technology insertion and refresh in program planning

Use Modular Open Systems Architecture to stimulate innovation

Increase the return on Small Business Innovation Research (SBIR)

Provide draft technical requirements to industry early and involve industry in funded concept definition to support requirements definition

- Provide clear "best value" definitions so industry can propose and DoD can choose wisely

\section{Continue Strengthening Our Culture of: \\ Continue Strengthening Our Culture of:
Cost Consciousness, Professionalism, and Technical Excellence}

Eliminate Unproductive Processes and Bureaucracy

Emphasize Acquisition Executive, Program Executive Officer and Program Manager responsibility, authority, and accountability

- Reduce cycle times while ensuring sound investments

Streamline documentation requirements and staff reviews

Promote Effective Competition

- Create and maintain competitive environments

Improve technology search and outreach in global markets

Improve Tradecraft in Acquisition of Services

- Increase small business participation, including more effective use of market research

Strengthen contract management outside the normal acquisition chain

- Improve requirements definition

- Improve the effectiveness and productivity of contracted engineering and technical services

Improve the Professionalism of the Total Acquisition Workforce

- Establish higher standards for key leadership positions

Establish stronger professional qualification requirements

for all acquisition specialties

- Strengthen organic engineering capabilities

Ensure the DOD leadership for development programs is technically qualified to manage R\&D activities

Improve our leaders' ability to understand and mitigate technical risk

- Increase DoD support for Science, Technology, Engineering and Mathematics (STEM) education

\section{Resources}

BBP 3.0: Achieving Dominant Capabilities through Technical Excellence and Innovation

\section{We Want Your Feedback!}

\section{Reference The Better Buying Power Website for past and current BBP resource materials}

bbp.dau.mil

Join our conversation:

OSD.ATL.BBP@mail.mil 


\section{Appendix B - Contracting Certification Curriculum}

The following are certification standards from the DAU on-line iCatalog (as of 31 December

2015) for Contracting certification levels I, II, and III. (Defense Acquisition University, 2015a)

\begin{tabular}{|c|c|}
\hline \multicolumn{2}{|r|}{ CONTRACTING LEVEL1 } \\
\hline $\begin{array}{l}\text { Type of } \\
\text { Assignment }\end{array}$ & Representative Activities \\
\hline $\begin{array}{l}1 \text { - Operational } \\
\text { Contracting } \\
\end{array}$ & - Contracting functions in support of post, camp or stations \\
\hline $\begin{array}{l}2 \text { - Research and } \\
\text { Development }\end{array}$ & - Contracting functions in support of research and development \\
\hline 3 - Sys Acquisition & $\begin{array}{l}\text { - Contracting functions in support of systems acquisition to include all ACAT } \\
\text { programs }\end{array}$ \\
\hline $\begin{array}{l}4 \text { - Logistics and } \\
\text { Sustainment }\end{array}$ & $\begin{array}{l}\text { - Contracting functions performed by the Defense Logistics Agency or by other } \\
\text { offices to sustain weapon systems }\end{array}$ \\
\hline $\begin{array}{l}5 \text { - Construction/ } \\
\text { A\&E }\end{array}$ & $\begin{array}{l}\text { - Contracting functions in support of construction and/or architect and } \\
\text { engineering services }\end{array}$ \\
\hline $\begin{array}{l}6 \text { - Contingency/ } \\
\text { Combat Ops }\end{array}$ & - Contracting functions performed in a contingency or combat environment \\
\hline $\begin{array}{l}7 \text { - Contract Admin } \\
\text { Office }\end{array}$ & - Contracting function is primarily focused on contract administration \\
\hline $\begin{array}{l}\text { - Contract } \\
\text { Cost/Price Analyst }\end{array}$ & - Contracting function is primarily focused on advanced cost/price analysis \\
\hline $\begin{array}{l}9 \text { - Small Bus } \\
\text { Specialist }\end{array}$ & $\begin{array}{l}\text { - Contracting function is primarily focused on advising small businesses or on } \\
\text { strategies for maximizing use of small businesses }\end{array}$ \\
\hline 10 - Other & $\begin{array}{l}\text { - Contracting functions that perform a variety of assignments or are at a } \\
\text { headquarters, secretariat, or OSD }\end{array}$ \\
\hline
\end{tabular}

\begin{tabular}{|c|c|}
\hline \multicolumn{2}{|r|}{ Core Certification Standards (Required for DAWIA certification.) } \\
\hline Acquisition Training & - None required \\
\hline Functional Training & 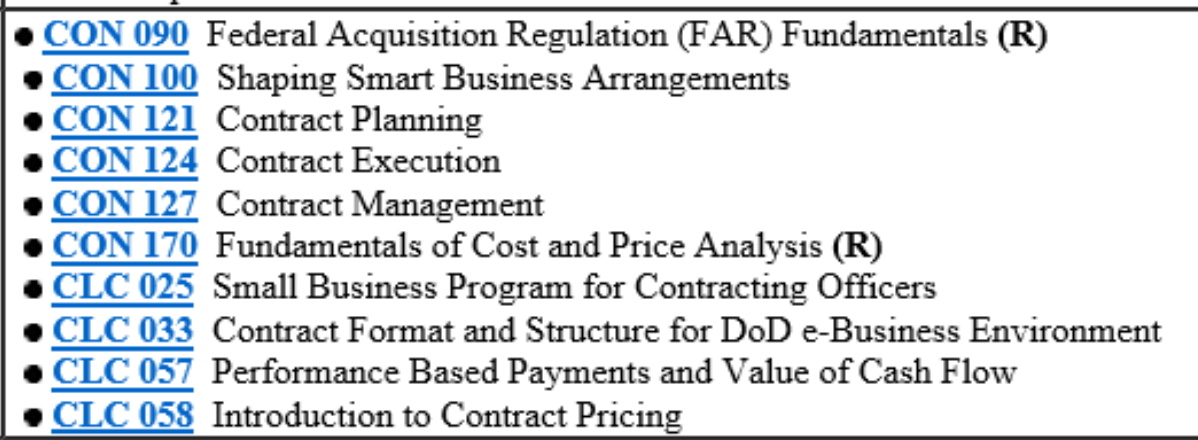 \\
\hline Education & $\begin{array}{l}\text { - At least } 24 \text { semester hours in accounting, law, business, finance, contracts, } \\
\text { purchasing, economics, industrial management, marketing, quantitative methods, } \\
\text { or organization and management } \\
\text { - Baccalaureate degree (Any Field of Study) }\end{array}$ \\
\hline Experience & - 1 year of contracting experience. \\
\hline
\end{tabular}




\section{CERTIFICATION STANDARDS \& CORE PLUS DEVELOPMENT GUIDE CONTRACTING LEVEL2}

\begin{tabular}{|c|c|}
\hline $\begin{array}{l}\text { Type of } \\
\text { Assignment }\end{array}$ & Representative Activities \\
\hline $\begin{array}{l}1 \text { - Operational } \\
\text { Contracting }\end{array}$ & - Contracting functions in support of post, camp or stations \\
\hline 2 - Res \& Dev & - Contracting functions in support of research and development \\
\hline 3 - Sys Acq & $\begin{array}{l}\text { - Contracting functions in support of systems acquisition to include all ACAT } \\
\text { programs }\end{array}$ \\
\hline $\begin{array}{l}4 \text { - Logistics and } \\
\text { Sustainment }\end{array}$ & $\begin{array}{l}\text { - Contracting functions performed by the Defense Logistics Agency or by other } \\
\text { offices to sustain weapon systems }\end{array}$ \\
\hline $\begin{array}{l}5 \text { - Construction/ } \\
\text { A\&E }\end{array}$ & $\begin{array}{l}\text { - Contracting functions in support of construction and/or architect and } \\
\text { engineering services }\end{array}$ \\
\hline $\begin{array}{l}6 \text { - Contingency/ } \\
\text { Combat Ops }\end{array}$ & - Contracting functions performed in a contingency or combat environment \\
\hline $\begin{array}{l}7 \text { - Contract Admin } \\
\text { Office }\end{array}$ & - Contracting function is primarily focused on contract administration \\
\hline $\begin{array}{l}8 \text { - Contract } \\
\text { Cost/Price Analyst }\end{array}$ & - Contracting function is primarily focused on advanced cost/price analysis \\
\hline $\begin{array}{l}9 \text { - Small Bus } \\
\text { Specialist }\end{array}$ & $\begin{array}{l}\text { - Contracting function is primarily focused on advising small businesses or on } \\
\text { strategies for maximizing use of small businesses }\end{array}$ \\
\hline 10 - Other & $\begin{array}{l}\text { - Contracting functions that perform a variety of assignments or are at a } \\
\text { headquarters, secretariat, or OSD }\end{array}$ \\
\hline
\end{tabular}

\begin{tabular}{|c|c|}
\hline \multicolumn{2}{|r|}{ Core Certification Standards (Required for DAWIA certification.) } \\
\hline Acquisition Training & - ACQ 101 Fundamentals of Systems Acquisition Management \\
\hline Functional Training & 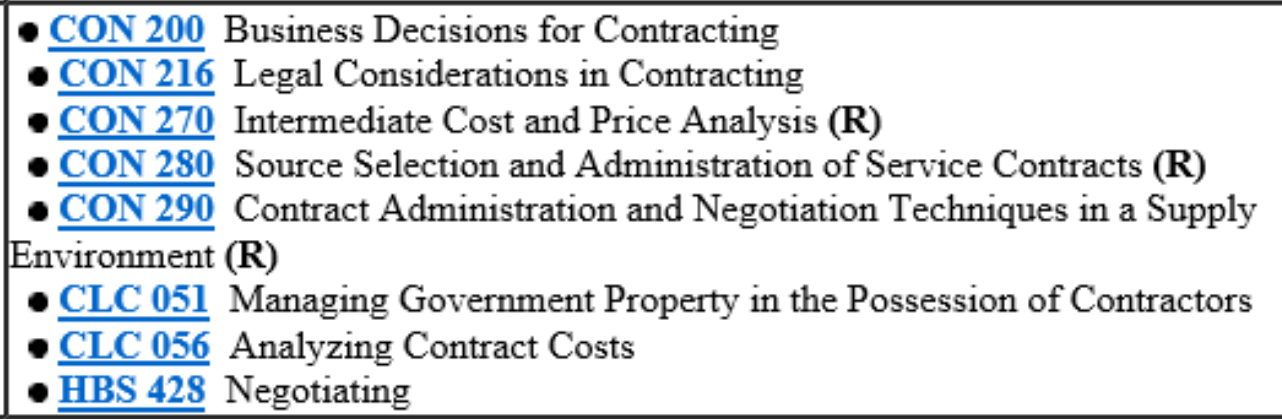 \\
\hline Education & $\begin{array}{l}\text { - At least } 24 \text { semester hours in accounting, law, business, finance, contracts, } \\
\text { purchasing, economics, industrial management, marketing, quantitative methods, } \\
\text { or organization and management } \\
\text { - Baccalaureate degree (Any Field of Study) }\end{array}$ \\
\hline Experience & - 2 years of contracting experience. \\
\hline
\end{tabular}

(Defense Acquisition University, 2015a) 


\section{CERTIFICATION STANDARDS \& CORE PLUS DEVELOPMENT GUIDE CONTRACTING LEVEL3}

\begin{tabular}{|c|c|}
\hline $\begin{array}{l}\text { Type of } \\
\text { Assignment }\end{array}$ & Representative Activities \\
\hline $\begin{array}{l}1 \text { - Operational } \\
\text { Contracting }\end{array}$ & - Contracting functions in support of post, camp or stations \\
\hline 2 - Res \& Dev & - Contracting functions in support of research and development \\
\hline 3 - Sys Acq & $\begin{array}{l}\text { - Contracting functions in support of systems acquisition, to include all ACAT } \\
\text { programs }\end{array}$ \\
\hline $\begin{array}{l}4 \text { - Logistics and } \\
\text { Sustainment }\end{array}$ & $\begin{array}{l}\text { - Contracting functions performed by the Defense Logistics Agency or by other } \\
\text { offices to sustain weapon systems }\end{array}$ \\
\hline $\begin{array}{l}5 \text { - Construction/ } \\
\text { A\&E }\end{array}$ & $\begin{array}{l}\text { - Contracting functions in support of construction and/or architect and } \\
\text { engineering services }\end{array}$ \\
\hline $\begin{array}{l}6 \text { - Contingency/ } \\
\text { Combat Ops }\end{array}$ & - Contracting functions performed in a contingency or combat environment \\
\hline $\begin{array}{l}7 \text { - Contract Admin } \\
\text { Office }\end{array}$ & - Contracting function is primarily focused on contract administration \\
\hline $\begin{array}{l}8 \text { - Contract } \\
\text { Cost/Price Analyst }\end{array}$ & - Contracting function is primarily focused on advanced cost/price analysis \\
\hline $\begin{array}{l}9 \text { - Small Bus } \\
\text { Specialist }\end{array}$ & $\begin{array}{l}\text { - Contracting function is primarily focused on advising small businesses or on } \\
\text { strategies for maximizing use of small businesses }\end{array}$ \\
\hline 10 - Other & $\begin{array}{l}\text { - Contracting functions that perform a variety of assignments or are at a } \\
\text { headquarters, secretariat, or OSD }\end{array}$ \\
\hline
\end{tabular}

\begin{tabular}{|c|c|}
\hline \multicolumn{2}{|r|}{ Core Certification Standards (Required for DAWIA certification.) } \\
\hline Acquisition Training & - $\underline{\text { ACQ } 202}$ Intermediate Systems Acquisition, Part A \\
\hline Functional Training & $\begin{array}{l}\text { CON } 360 \text { Contracting for Decision Makers (R) } \\
\text { - } 1 \text { additional course from the Harvard Business Management Modules } \\
\text { Elective Requirement. Select one of the below courses: } \\
\text { - ACQ 265 Mission-Focused Services Acquisition (R) } \\
\text { ACQ } 315 \text { Understanding Industry (Business Acumen) (R) } \\
\text { ACQ } 370 \text { Acquisition Law (R) } \\
\text { AON 232 Overhead Management of Defense Contracts (R) } \\
\text { CON } 244 \text { Construction Contracting (R) } \\
\text { CON 252 Fundamentals of Cost Accounting Standards (R) } \\
\text { CON } 334 \text { Advanced Contingency Contracting Officer's Course (R) } \\
\text { CON } 370 \text { Advanced Contract Pricing (R) }\end{array}$ \\
\hline Education & $\begin{array}{l}\text { - At least } 24 \text { semester hours in accounting, law, business, finance, contracts, } \\
\text { purchasing, economics, industrial management, marketing, quantitative methods, } \\
\text { or organization and management } \\
\text { - Baccalaureate degree (Any Field of Study) }\end{array}$ \\
\hline Experience & 4 years of contracting experience \\
\hline
\end{tabular}

(Defense Acquisition University, 2015a) 


\section{Contracting Certification Course Descriptions}

The following are quoted course descriptions from the Defense Acquisition University on-line iCatalog (as of 31 December 2015) for Contracting certification levels I, II, and III. Highlighting of text is added by the researcher to indicate the inclusion of a critical thinking emphasis or reference in the iCatalog description.

Mandatory Level I Contracting certification courses (Defense Acquisition University, 2015a):

\section{CON 090 Federal Acquisition Regulation (FAR) Fundamentals}

FAR Fundamentals is a four week, resident, foundational course for new hires that provides a total immersion into the Federal Acquisition Regulation (Parts 1-53) and the Defense Federal Acquisition Regulation Supplement (DFARS). The course will prepare the 21st century acquisition workforce to operate successfully in a web enabled environment. CON 090 is a limited lecture, research-intensive, exercised-based curriculum. Participants will analyze contracting business scenarios developed through research of the FAR and its supplement DFARS. The course is presented in four modules: Contracting Overview using the FAR and DFARS; Contract Acquisition Planning; Contract Formation; and Contract Management/ Administration. Students are expected to become familiar with FAR Parts 1-53. Students will be quizzed daily on FAR part knowledge, lecture/lesson content, and homework. Students should be prepared to dedicate 2-3 hours per evening for homework. Classroom laptop computers will be provided for each student.

\section{CON 100 Shaping Smart Business Arrangements}

Personnel new to the Contracting career field will gain a broad understanding of the environment in which they will serve. Students will develop professional skills for making business decisions and for advising acquisition team members in successfully meeting customers' needs. Before beginning their study of technical knowledge and contracting procedures, students will learn about the various Department of Defense (DoD) mission areas and the types of business arrangements and procurement alternatives commonly used to support each area. Information systems, knowledge management, as well as recent DoD acquisition initiatives will be also be introduced in the course. Additionally, interactive exercises will prepare you for contracting support within the DoD. We will also address the overarching business relationships of government and industry, and the role of politics and customer relationships.

\section{CON 121 Contract Planning}

Contract Planning will introduce personnel new to the contracting field to their role as a business advisor in the acquisition process. It focuses on the students' role in understanding their customers' mission and their ability to plan successful mission support strategies based upon their knowledge of the contracting environment and their customer needs. Students will learn how to use the Federal Acquisition Regulation (FAR) and Defense Federal Acquisition 
Regulation Supplement (DFARS), conduct effective market research, develop alternative acquisition strategies, and understand how socioeconomic programs support the acquisition planning process.

\section{CON 124 Contract Execution}

Contract Execution is the second of three online Level I contracting courses. It focuses on executing the acquisition planning through soliciting industry and awarding a contract. It provides students with the knowledge necessary to execute an acquisition that optimizes customer mission performance. Students will learn the techniques and benefits of early industry involvement in shaping requirements. Students will learn basic procedures for acquisition of both commercial and noncommercial requirements, effectively conduct analysis of market data, and determine when a price is fair and reasonable. Finally students will learn how to conduct basic competitive acquisitions, process awards, and handle protests before and after contract award.

\section{CON 127 Contract Management}

Contract Management is the final of three online courses. This course builds on the foundation established in CON 121 and CON 124 and provides students with the knowledge necessary to identify and utilize appropriate performance metrics when evaluating contractor performance. Students will explore processes for working with their customer to ensure contract performance is meeting mission requirements. Students will explore performance assessment strategies and remedies for contractual non-compliance, how to make and price contract changes after award, handle disputes, and finally how to close out completed contracts. Additionally, students will gain a fundamental knowledge of the characteristics and principles of the contract termination process.

\section{CON 170 Fundamentals of Cost and Price Analysis}

The course begins with an in-depth review of the Market Research process, and provides instruction to help students understand and analyze contractor pricing strategies. Students will learn to accomplish Cost-Volume-Profit analysis, calculate contribution margin estimates, and develop cost estimating relationships in order to accomplish an effective price analysis pursuant to FAR Subpart 15.4. The course provides an overview regarding the regulations and processes regarding the use of cost analysis, and for requiring certified cost and pricing data. Finally, after learning the basic elements of price and cost analysis, students will build and defend a prenegotiation objective, including a minimum and maximum pricing objective with a Weighted Guidelines assessment. Students are also provided in-depth instruction on contract financing techniques, including the development and administration of progress payments based on cost and performance based payments. Students will become proficient with the use of the PBP Analysis Tool.

\section{CLC 025 Small Business Program for Contracting Officers}

This module explains the role of the Contracting Officer in working with small businesses in the DoD Acquisition Program. DoD policy is that a fair proportion of DoD total purchases and contracts be placed with Small Business Programs and that such small businesses have the maximum practicable opportunity to participate in DoD acquisitions. 


\section{CLC 033 Contract Format and Structure for DoD e-Business Environment}

Effective structuring of contracts is more important than ever. This is due to the increased automation of the contracting process and centralization of bill paying through the Defense Finance and Accounting Service; a loss of institutional knowledge among the DoD procurement workforce; and requirements for proper valuation and tracking of equipment.

\section{CLC 057 Performance Based Payments and Value of Cash Flow}

This module provides an introduction and overview for Performance Based Payments as it applies to structuring and negotiating Win-Win PBP agreements with contractors. A tutorial on the use of the PBP Analysis Tool is also provided.

\section{CLC 058 Introduction to Contract Pricing}

During the most recent Contracting Competency Assessment, senior leadership from all services and agencies viewed cost and price analysis as a fundamental skill for contracting professionals to focus on early in their contracting careers. As a result, the Defense Acquisition University is infusing cost and price analysis into the entire Defense Acquisition Workforce Improvement Act (DAWIA) curriculum, beginning with the fundamental topics and issues presented in CLC 058, Introduction to Contract Pricing, a Level I certification requirement and prerequisite to CON 170, Fundamentals of Cost and Price Analysis.

\section{Mandatory Level II Contracting certification courses (Defense Acquisition University,} 2015a):

\section{CON 200 Business Decisions for Contracting}

Business Decisions for Contracting builds on contracting Level I pre-award business and contracting knowledge necessary to process complex procurements. The emphasis of this course is on planning successful mission-support strategies and executing an acquisition that optimizes customer mission performance. Participants will learn various techniques for building successful business relationships, the benefits of strategic sourcing and spend analysis, and the ins and outs of providing contract financing. Students will also take an in-depth look at subcontracting, how to conduct a formal source selection, and how to analyze the information necessary to determine contractor responsibility.

\section{CON 216 Legal Considerations in Contracting}

This course focuses on legal considerations in the procurement process. Participants are introduced to the basic principles and sources of law relevant to procurement, including fiscal law. The course also addresses various other legal issues that may develop during the course of a contract, such as protests, assignment of claims, disputes, fraud, contractor debt, performance issues, and contract termination.

\section{CON 270 Intermediate Cost and Price Analysis}

Intermediate Cost and Price Analysis continues to build upon the fundamental contract pricing principles covered in the Level I Contracting curriculum, Contract Pricing Reference Guide, and DOD Policy. The course is divided into three segments addressing contract pricing issues from a 
Pre-Award, Negotiation Preparation-Award, and Post-Award perspective. In the course students will be introduced to quantitative techniques and tools used to quantify and facilitate decision making in determining a fair and reasonable price. Students will apply various cost analysis techniques and quantitative tools to analyze a contractor's cost proposal and to develop a government negotiation range and objective. The course is designed to prepare students for follow on DAWIA Level II certification courses, serve as a gateway into more advanced targeted contract pricing courses, and give the students some practical tools in pricing government contracts. The ultimate objective of the course is to help students become better business advisors in developing contract arrangements that are in the best interest of the government.

\section{CON 280 Source Selection and Administration of Service Contracts}

This course builds on the foundation established through the Level I curriculum and the course prerequisites. The primary focus is on the acquisition of services under FAR Part 15 procedures, with an emphasis on performance-based acquisitions (PBA) for services, contract types, contract incentives, source selection, and contract administration. Students will learn the fundamentals of a performance based service acquisition -- from acquisition planning to contract closeout through a realistic case study. The course takes students through the solicitation process using the mandatory DoD Source Selection Procedures. Students will prepare contractual documents, and develop and deliver high-level source selection briefings with recommendations for contract award.

CON 290 Contract Administration and Negotiation Techniques in a Supply Environment In this case-based course, students apply Contracting concepts and techniques learned in prerequisite courses to meet customer supply requirements and resolve complex Contracting issues. Special emphasis is placed on applying legal concepts from CON 216, intermediate pricing concepts from CON 270, and negotiation techniques from HBS 428. Students experience the full spectrum of Contracting processes and issues by following a supply requirement through all phases of the acquisition life cycle, from acquisition planning through contract close-out. Research, analysis, and communication skills are honed through development and presentation of a critical thinking project requiring in-depth focus on one area of Contracting. Negotiation skills are sharpened through active student participation in two simulated contract negotiations.

\section{CLC 051 Managing Government Property in the Possession of Contractors}

This course provides an overview of the policies, processes, and procedures used to manage Government property in the possession of contractors. It also introduces the concept of Government property, terminology used in the management of Government property, and accounting and treatment of Government property in the possession of contractors.

\section{CLC 056 Analyzing Contract Costs}

In this module, the student assumes the role of a contract specialist/intern who has been afforded the opportunity to work with the Contracting Officer of a large complex base operating services contract. The Contracting Officer acts as a mentor, providing guidance and direction as the student performs various cost and price analysis tasks. 


\section{HBS 428 Negotiating}

In this module you will learn about the negotiation process, when different types of negotiations are appropriate, essential negotiating strategies, and how to become an effective negotiator. This module includes a practical guide to becoming an effective negotiator. It includes steps to guide you through the negotiation process: assessing your interests as well as those of the other party, developing opportunities that create value, avoiding common barriers to agreement, and implementing strategies to make the negotiation process run smoothly.

Mandatory Level III Contracting certification courses (Defense Acquisition University, 2015a):

\section{CON 360 Contracting for Decision Makers}

Through realistic scenario-based learning, students work individually and in teams to practice developing sound business solutions as a valued strategic and expert business advisor. Students will learn to analyze complex contracting situations with emphasis on critical thinking, problem solving, research, and risk reduction. Student course work is designed to contribute real solutions on real acquisition problems to senior leadership and local supervisors.

Level III Certification Electives (Defense Acquisition University, 2015b):

\section{ACQ 265 Mission-Focused Services Acquisition}

This course is designed to improve our tradecraft in the acquisition of services. It uses a multifunctional approach that provides acquisition team members with the tools and techniques necessary to analyze and apply performance-based principles when developing requirements documents and effective business strategies for contractor-provided services. The course uses the seven-step Service Acquisition process, a team-oriented approach, and multiple interactive, hands-on, learning sessions to apply the principles. ACQ 265 is designed for individuals who need to improve their skills in developing and defining service requirements, supporting business strategies, and effectively managing the resulting contractor performance. However, this course may also serve as an opportunity for experienced acquisition personnel to improve their understanding of the Service Acquisition Process.

\section{ACQ 315 Understanding Industry (Business Acumen)}

Course covers a wide range of business acumen competencies including industry orientation, organization, cost and financial planning, business strategy/development, supplier management, incentives, and negotiating strategies. Business skills will be learned on aligning company strategies, finances, and operations that motivate company decisions to meet their business goals, gain fair and reasonable profits, while providing best taxpayer value to the government on defense products.

\section{ACQ 370 Acquisition Law}

DoD policy now mandates that the acquisition process be conducted through integrated product teams. The employment of integrated product teams in the acquisition process has resulted in the involvement of many non-contracting government personnel. ACQ 370 provides an overview of 
government contract law, specifically laws and regulations that are applicable to government contracts.

Note: Teaching includes case studies.

\section{CON 232 Overhead Management of Defense Contracts}

Overhead Management of Defense Contracts provides an understanding of industry overhead costs and the costs' impact on seller pricing/business strategies under various acquisition environments with differing contract types. Attendees will understand the development and application of overhead rates used in contract formation, administration, and closeout. The course-integrating case study provides hands-on application of the overhead-rate process in which attendees determine their own final overhead rates.

\section{CON 244 Construction Contracting}

This course focuses on unique construction contracting issues, such as acquisition planning, contract performance management, funding, environmental concerns, construction contract language, construction contracting in the commercial setting, the Construction Wage Rate Requirements Statute, design/build, basic schedule delay analysis, constructive changes, acceleration, and construction contract quality management.

\section{CON 252 Fundamentals of Cost Accounting Standards}

Fundamentals of Cost Accounting Standards provides detailed, hands-on instruction in the various aspects of Public Law 100-679, including the rules and regulations of the Cost Accounting Standards Board, the requirements of the cost accounting standards, disclosure statements, cost accounting practice changes, and calculating cost impacts for federal contracts.

\section{CON 334 Advanced Contingency Contracting Officer's Course}

Advanced Contingency Contracting develops skills for people who will be running the contingency contracting support operation provided to Joint Forces across the full spectrum of military operations. Exercises focus on unique aspects of contingency operations, critical thinking skills, and the execution of appropriate contractual instruments. Attendees will gain insight into tactical and strategic Contingency Contracting Mission Support and Operational Contract Support (OCS) Doctrine.

\section{CON 370 Advanced Contract Pricing}

CON370 uses a scenario-based approach to lead students to a deeper understanding of defense acquisition policy; the factors effecting price comparability; and quantitative analysis techniques. Topics include: selected areas of business microeconomics; interpreting and shaping regulatory policy; data normalization; forecasting techniques; Monte Carlo risk analysis; simple linear, nonlinear, and multivariate regression techniques; and cost improvement curve methodologies such as the unit and cumulative average formulations, and dealing with breaks in production. 


\section{Appendix C - Contracting Workforce Survey}

Retrieved from Opinio survey tool on 16 Jan 2016

\section{DEFENSE ACQUISITION UNIVERSITY}

Learn. Perform. Succeed.

\section{Critical Thinking Training Survey}

This survey was developed to determine if contracting professionals have been trained to develop their critical thinking skills to assist them in making sound business decisions and implement Better Buying Power initiatives. Your responses should be based on your own training experiences.

The results of this survey will be used to determine if there is need for additional, different, or earlier training to further develop critical thinking skills. If you have questions about this survey, please contact Cheryl Jones at email cheryl.jones@dau.mil.

Your anonymity will be protected. Please provide your candid responses.

Critical Thinking Training Survey

\section{Consent Statement}

1. I understand that this survey is for academic purposes and all responses are anonymous. I also read the attached Informed Content Statement (Attachment 1) and:

OI agree to participate. OI prefer not to participate.

\begin{tabular}{l|l} 
Back & Next
\end{tabular}

\section{Critical Thinking Training Survey}

\section{Demographic and Position Questions}

2. What classification best describes your current status? (Select one response.) 
Critical Thinking Training Survey

3. What is your rank or paygrade? (Select one response.)

DAC GS-11 and below or $\mathrm{NH}-\mathrm{II}$

4. What is your generational description and gender? (Select one response.)

\begin{tabular}{|l|c|c|}
\hline Birth Years (Generation) & \multicolumn{3}{|c|}{ Male Female } \\
\hline $1985-2000$ (Millennials) & $\bigcirc$ & 0 \\
\hline $1965-1984$ (Generation Xers) & 0 & 0 \\
\hline $1946-1964$ (Baby Boomers) & 0 & 0 \\
\hline $1925-1945$ (Silent Generation) & 0 & 0 \\
\hline
\end{tabular}

Back 1 Next

Critical Thinking Training Survey

5. How many years of contracting experience do you have and in what capacity? (Select all that apply.)

\begin{tabular}{|c|c|c|c|c|c|}
\hline $\begin{array}{l}\text { Years of } \\
\text { Experience }\end{array}$ & $\begin{array}{l}\text { Government } \\
\text { Civilian }\end{array}$ & $\begin{array}{l}\text { Military (Active } \\
\text { \& Reserves) }\end{array}$ & $\begin{array}{c}\text { Local } \\
\text { National }\end{array}$ & $\begin{array}{l}\text { Private } \\
\text { Industry }\end{array}$ & Other \\
\hline NA & $\square$ & $\square$ & $\square$ & $\square$ & $\square$ \\
\hline Under 2 Years & $\square$ & $\square$ & $\square$ & $\square$ & $\square$ \\
\hline 2-4 Years & $\square$ & $\square$ & $\square$ & $\square$ & $\square$ \\
\hline 5-6 Years & $\square$ & $\square$ & $\square$ & $\square$ & $\square$ \\
\hline 7-8 Years & $\square$ & $\square$ & $\square$ & $\square$ & $\square$ \\
\hline 9-10 Years & $\square$ & $\square$ & $\square$ & $\square$ & $\square$ \\
\hline 11-12 Years & $\square$ & $\square$ & $\square$ & $\square$ & $\square$ \\
\hline 13-14 Years & $\square$ & $\square$ & $\square$ & $\square$ & $\square$ \\
\hline 15-16 Years & $\square$ & $\square$ & $\square$ & $\square$ & $\square$ \\
\hline 17-18 Years & $\square$ & $\square$ & $\square$ & $\square$ & $\square$ \\
\hline 19-20 Years & $\square$ & $\square$ & $\square$ & $\square$ & $\square$ \\
\hline 21-22 Years & $\square$ & $\square$ & $\square$ & $\square$ & $\square$ \\
\hline 23-24 Years & $\square$ & $\square$ & $\square$ & $\square$ & $\square$ \\
\hline 25-26 Years & $\square$ & $\square$ & $\square$ & $\square$ & $\square$ \\
\hline 27-28 Years & $\square$ & $\square$ & $\square$ & $\square$ & $\square$ \\
\hline 29-30 Years & $\square$ & $\square$ & $\square$ & $\square$ & $\square$ \\
\hline Over 30 Years & $\square$ & $\square$ & $\square$ & $\square$ & $\square$ \\
\hline
\end{tabular}




\section{Critical Thinking Training Survey}

6. When were you certified at the various levels in Contracting? Note: If you can't recall your exact certification date, please use your best estimate.

(Select all that apply.)

\section{Year Certified Level I Level II Level III}

Not yet certified at this level

2013-2016

$2010-2012$

2007-2009

2004-2006

2001-2003

$1998-2000$

1995-1997

1992-1994

1989-1991

1986-1988

Before 1986

Grandfathered at this level

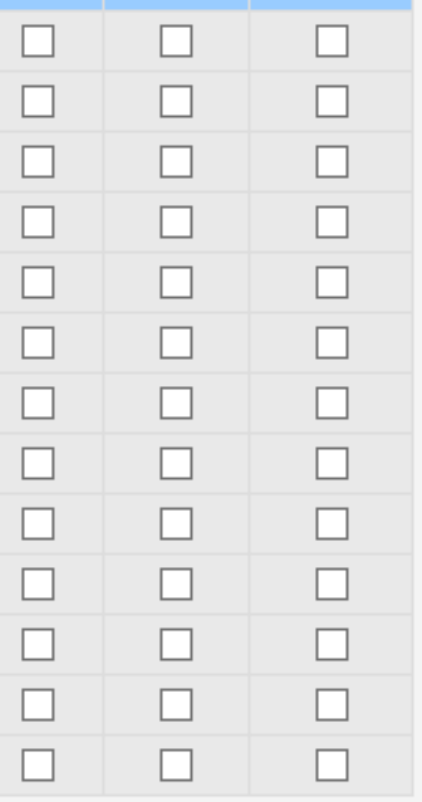

7. What is the highest educational degree you have earned? (Select one response. Local nationals - please use general equivalency level.)

No degree $\quad \checkmark$

8. Which ACC Command do you currently work for? (Select one response.)

Headquarters ACC $\quad \checkmark$

\section{Back $\quad$ Next}

Critical Thinking Training Survey

This survey asks several questions about critical thinking concepts. To define and introduce a common reference point for survey participants, Attachment 2 is provided for your reference and defines critical thinking skills and competencies.

9. Have you had training to develop your critical thinking abilities? How did you receive this training? How effective was it?

Several possible sources for critical thinking training are listed below. For each source, indicate if you received critical thinking training in the manner listed and, if received, rank the effectiveness of the training (on a scale with 1 = totally ineffective and $7=$ extremely effective). 


\begin{tabular}{|c|c|c|c|c|c|c|c|c|c|c|}
\hline & Recei & ived Tra & aining & & & Traini & ing Effective & eness & & \\
\hline $\begin{array}{l}\text { Critical } \\
\text { Thinking } \\
\text { Training } \\
\text { Source }\end{array}$ & $\begin{array}{l}\text { No, I } \\
\text { didn't } \\
\text { receive } \\
\text { critical } \\
\text { thinking } \\
\text { training } \\
\text { in this } \\
\text { manner }\end{array}$ & $\begin{array}{l}\text { Can't } \\
\text { Recall }\end{array}$ & $\begin{array}{c}\text { Yes, I } \\
\text { received } \\
\text { critical } \\
\text { thinking } \\
\text { training } \\
\text { and it } \\
\text { was: }\end{array}$ & $\begin{array}{l}\text { I - Totally } \\
\text { Ineffective }\end{array}$ & $\begin{array}{c}2- \\
\text { Ineffective }\end{array}$ & $\begin{array}{l}3 \text { - } \\
\text { Somewhat } \\
\text { Ineffective }\end{array}$ & $\begin{array}{c}4- \\
\text { Neither } \\
\text { Effective } \\
\text { Nor } \\
\text { Ineffective }\end{array}$ & $\begin{array}{c}5- \\
\text { Somewhat } \\
\text { Effective }\end{array}$ & $\begin{array}{c}6- \\
\text { Effective }\end{array}$ & $\begin{array}{c}7- \\
\text { Extremely } \\
\text { e Effective }\end{array}$ \\
\hline $\begin{array}{l}\text { DAU } \\
\text { Contracting } \\
\text { Certification } \\
\text { Courses }\end{array}$ & 0 & 0 & 0 & 0 & 0 & 0 & 0 & 0 & 0 & 0 \\
\hline $\begin{array}{l}\text { Other DAU } \\
\text { courses }\end{array}$ & 0 & 0 & 0 & 0 & 0 & 0 & 0 & 0 & 0 & 0 \\
\hline $\begin{array}{l}\text { Other DoD } \\
\text { provided } \\
\text { civilian } \\
\text { courses }\end{array}$ & 0 & 0 & 0 & 0 & 0 & 0 & 0 & 0 & 0 & 0 \\
\hline $\begin{array}{l}\text { Other DoD } \\
\text { provided } \\
\text { military } \\
\text { courses }\end{array}$ & 0 & 0 & 0 & 0 & 0 & 0 & 0 & 0 & 0 & 0 \\
\hline $\begin{array}{l}\text { Formal } \\
\text { education } \\
\text { (such as } \\
\text { college } \\
\text { courses) }\end{array}$ & 0 & 0 & 0 & 0 & 0 & 0 & 0 & 0 & 0 & 0 \\
\hline $\begin{array}{l}\text { Professional } \\
\text { association } \\
\text { course }\end{array}$ & 0 & 0 & 0 & 0 & 0 & 0 & 0 & 0 & 0 & 0 \\
\hline $\begin{array}{l}\text { On-the-job } \\
\text { contracting } \\
\text { work } \\
\text { experience }\end{array}$ & 0 & 0 & 0 & 0 & 0 & 0 & 0 & 0 & 0 & 0 \\
\hline $\begin{array}{l}\text { Other on-the- } \\
\text { job work } \\
\text { experience }\end{array}$ & 0 & 0 & 0 & 0 & 0 & 0 & 0 & 0 & 0 & 0 \\
\hline $\begin{array}{l}\text { From a } \\
\text { mentor or } \\
\text { coach }\end{array}$ & 0 & 0 & 0 & 0 & 0 & 0 & 0 & 0 & 0 & 0 \\
\hline $\begin{array}{l}\text { Self-taught } \\
\text { (through } \\
\text { personal } \\
\text { development, } \\
\text { reading, } \\
\text { discussion, } \\
\text { problem } \\
\text { solving } \\
\text { activities, } \\
\text { ctc.? }\end{array}$ & 0 & 0 & 0 & 0 & 0 & 0 & 0 & 0 & 0 & 0 \\
\hline $\begin{array}{l}\text { Other } \\
\text { method } \\
\text { (please list } \\
\text { below and } \\
\text { provide } \\
\text { ranking } \\
\text { here.) }\end{array}$ & 0 & 0 & 0 & 0 & 0 & 0 & 0 & 0 & 0 & 0 \\
\hline & & & & & $\hat{\imath}$ & & & & & \\
\hline & & & & & & & & & & Back \\
\hline
\end{tabular}


Critical Thinking Training Survey

10. As a result of the critical thinking training you have had, do you think your critical thinking skills have imporved in the past 5 years?

OYes

ONo

ONA - I have not had critical thinking training

11. In the critical thinking training you have experienced, what would have made the training experience more effective for you? (Check all that apply.)

$\square$ Allow more training time for topic

$\square$ Allow more time for open discussion by class

$\square$ Having training conducted as classroom vs. distance training to allow for interaction with instructor and students

$\square$ Doing all or part of the training via distance training prior to classroom training

$\square$ Include more reading on critical thinking prior to classroom training

$\square$ Use (more) simulation based training (such as situational role playing)

$\square$ Use (more) hands-on exercises

$\square$ Use (more) case based training method

$\square$ No known way to make training more effective

$\square$ Other (please list below):

(1)

12. If you haven't taken a course that included applying critical thinking skills and/or tools, why not? (Check all that apply).

$\square$ Not aware of any courses like this

$\square$ Course not available to me at time of application

$\square$ No time for this type of training

$\square$ No resources to attend

$\square$ My leadership does not support this type of training

$\square$ The subject is not relevant or important to my job

$\square$ I've taken other critical thinking training already and it would be repetitive

$\square$ Not interested in this type of training

$\square$ Other reason (please list below):

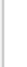

13. If you have completed your contracting certification coursework and are certified at level III, are there adequate training opportunities for additional training to enhance critical thinking skills?

OYes - there are adequate training opportunities

OUnknown - I don't know of these types of training opportunities

No - there are not adequate training opportunities

ONot applicable - I am not certified at level III yet 
Critical Thinking Training Survey

14. What type(s) of training would be most effective to enhance your critical thinking skills? (Select all that apply)

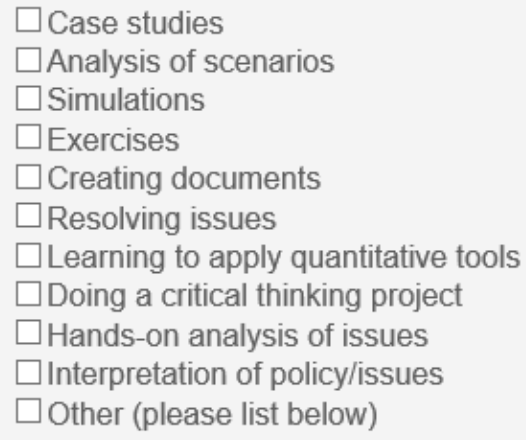

15. What critical thinking skills do you think are important to make sound business decisions or understand complex contracting issues? Rank each skill with $1=$ totally unimportant and $7=$ extremely important. If needed, definitions of these skills are available in Attachment 2.

\begin{tabular}{l|c|c|c|c|c|c|}
$\begin{array}{l}\text { Critical } \\
\text { Thinking } \\
\text { Skills }\end{array}$ & $\begin{array}{c}\text { 1-Totally } \\
\text { unimportant }\end{array}$ & 2-Unimportant & $\begin{array}{c}\text { 3-Somewhat } \\
\text { unimportant }\end{array}$ & $\begin{array}{c}\text { 4-Neither } \\
\text { unimportant } \\
\text { nor important }\end{array}$ & $\begin{array}{c}\text { 5-Somewhat } \\
\text { important }\end{array}$ & 6-Important \\
$\begin{array}{c}\text { 7-Extremely } \\
\text { important }\end{array}$
\end{tabular}

\begin{tabular}{|l|l|l|l|l|l|l|l|}
\hline Interpretation & 0 & 0 & 0 & 0 & 0 & 0 & 0 \\
\hline Analysis & 0 & 0 & 0 & 0 & 0 & 0 & 0 \\
\hline Inference & 0 & 0 & 0 & 0 & 0 & 0 & 0 \\
\hline Evaluation & 0 & 0 & 0 & 0 & 0 & 0 & 0 \\
\hline Explanation & 0 & 0 & 0 & 0 & 0 & 0 & 0 \\
\hline $\begin{array}{l}\text { Self- } \\
\text { regulation }\end{array}$ & 0 & 0 & 0 & 0 & 0 & 0 & 0 \\
\hline
\end{tabular}

Critical Thinking Training Survey

16. Have you ever had an assessment of your critical thinking skills?
OYes
ONo
Not sure 
Critical Thinking Training Survey

17. If you answered yes to previous question, did you think the assessment was accurate?
YYes
ONo
Not sure

18. Have you ever had an assessment of your disposition to use critical thinking skills?
OYes
ONo
Not sure

Back 1 Next

\section{Critical Thinking Training Survey}

19. If you answered yes to previous question, did you think the assessment was accurate?
OYes
No
Not sure

\section{Back $\quad$ Next}

Critical Thinking Training Survey

20. If you indicated that you had an assessment of your disposition to use critical thinking skills, what method was used to assess you?

$\square$ A person assessed me (such as a supervisor or team lead)

$\square$ I was assessed as part of a class

$\square$ I did an on-line assessment

$\square$ I used a critical thinking app

$\square$ Other (please list below) 
21. In relation to your contracting job duties, how often do you use critical thinking skills when making decisions on the following types of complex issues? Rank your use of critical thinking skills using a scale where $1=$ never use and $7=$ always use.

\begin{tabular}{|c|c|c|c|c|c|c|c|c|}
\hline $\begin{array}{l}\text { Complex issues for } \\
\text { contracting workforce } \\
\text { represented in Better } \\
\text { Buying Power initiatives }\end{array}$ & $\begin{array}{l}\text { NA - not } \\
\text { involved } \\
\text { with this } \\
\text { type of task }\end{array}$ & $\begin{array}{c}1- \\
\text { never } \\
\text { use }\end{array}$ & $\begin{array}{c}2 \\
- \text { infrequently } \\
\text { use }\end{array}$ & $\begin{array}{l}3 \text {-don't } \\
\text { routinely } \\
\text { use }\end{array}$ & $\begin{array}{c}4- \\
\text { sometimes } \\
\text { use }\end{array}$ & $\begin{array}{l}5- \\
\text { frequently } \\
\text { use }\end{array}$ & $\begin{array}{c}6- \\
\text { almost } \\
\text { always } \\
\text { use }\end{array}$ & $\begin{array}{l}7- \\
\text { always } \\
\text { use }\end{array}$ \\
\hline $\begin{array}{l}\text { Include cyber security } \\
\text { terms in contracts }\end{array}$ & 0 & 0 & 0 & 0 & 0 & 0 & 0 & 0 \\
\hline $\begin{array}{l}\text { Aligning profitability with } \\
\text { DoD goals }\end{array}$ & 0 & 0 & 0 & 0 & 0 & 0 & 0 & 0 \\
\hline $\begin{array}{l}\text { Using appropriate contract } \\
\text { types }\end{array}$ & 0 & 0 & 0 & 0 & 0 & 0 & 0 & 0 \\
\hline $\begin{array}{l}\text { Increase use of incentive } \\
\text { type contracts }\end{array}$ & 0 & 0 & 0 & 0 & 0 & 0 & 0 & 0 \\
\hline $\begin{array}{l}\text { Promote use of Modular } \\
\text { Open Systems } \\
\text { Architecture in systems }\end{array}$ & 0 & 0 & 0 & 0 & 0 & 0 & 0 & 0 \\
\hline $\begin{array}{l}\text { Increase use of Small } \\
\text { Business R\&D }\end{array}$ & 0 & 0 & 0 & 0 & 0 & 0 & 0 & 0 \\
\hline $\begin{array}{l}\text { Involve industry early in } \\
\text { development of technical } \\
\text { requirements }\end{array}$ & 0 & 0 & 0 & 0 & 0 & 0 & 0 & 0 \\
\hline $\begin{array}{l}\text { Provide clear and } \\
\text { objective best value } \\
\text { definitions to industry }\end{array}$ & 0 & 0 & 0 & 0 & 0 & 0 & 0 & 0 \\
\hline $\begin{array}{l}\text { Reduce cycle times while } \\
\text { ensuring sound } \\
\text { investments }\end{array}$ & 0 & 0 & 0 & 0 & 0 & 0 & 0 & 0 \\
\hline $\begin{array}{l}\text { Streamline documentation } \\
\text { requirements and staff } \\
\text { reviews }\end{array}$ & 0 & 0 & 0 & 0 & 0 & 0 & 0 & 0 \\
\hline $\begin{array}{l}\text { Remove unproductive } \\
\text { contract requirements } \\
\text { imposed on industry }\end{array}$ & 0 & 0 & 0 & 0 & 0 & 0 & 0 & 0 \\
\hline $\begin{array}{l}\text { Create and maintain } \\
\text { competitive environments }\end{array}$ & 0 & 0 & 0 & 0 & 0 & 0 & 0 & 0 \\
\hline $\begin{array}{l}\text { Increase Small Business } \\
\text { participation }\end{array}$ & 0 & 0 & 0 & 0 & 0 & 0 & 0 & 0 \\
\hline $\begin{array}{l}\text { More effective use of } \\
\text { market research }\end{array}$ & 0 & 0 & 0 & 0 & 0 & 0 & 0 & 0 \\
\hline $\begin{array}{l}\text { Strengthen contract } \\
\text { management of services }\end{array}$ & 0 & 0 & 0 & 0 & 0 & 0 & 0 & 0 \\
\hline $\begin{array}{l}\text { Improve requirements } \\
\text { definition for services }\end{array}$ & 0 & 0 & 0 & 0 & 0 & 0 & 0 & 0 \\
\hline $\begin{array}{l}\text { Improve effectiveness and } \\
\text { productivity of contracted } \\
\text { engineering and technical } \\
\text { services }\end{array}$ & 0 & 0 & 0 & 0 & 0 & 0 & 0 & 0 \\
\hline $\begin{array}{l}\text { Improve understanding } \\
\text { and mitigation of } \\
\text { technical risk }\end{array}$ & 0 & 0 & 0 & 0 & 0 & 0 & 0 & 0 \\
\hline
\end{tabular}




\section{Appendix D - Contracting Faculty Survey}

Retrieved from Opinio survey tool on 16 Jan 2016

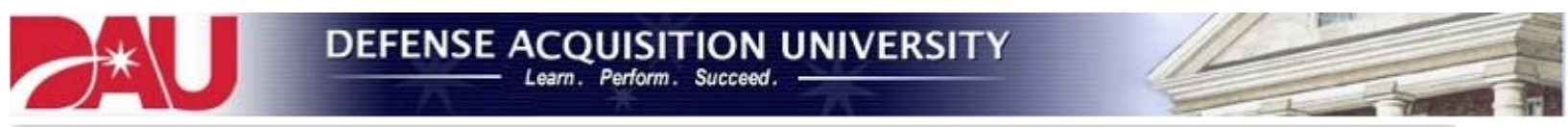

Critical Thinking Training Survey - Contracting Faculty

This survey was developed to determine if Army contracting professionals have been adequately trained to develop their critical thinking skills to assist them in making sound business decisions and implement Better Buying Power initiatives. Your responses should be based on your own experiences with DAU Contracting courses.

The results of this survey will be used to determine if there is need for additional, different, or earlier training to further develop critical thinking skills in the Army contracting workforce. If you have questions about this survey, please contact Cheryl Jones at email cheryl.jones@dau.mil.

Your anonymity will be protected. Please provide your candid responses.

Start

Critical Thinking Training Survey - Contracting Faculty

\section{Consent Statement}

1. I have read the attached Informed Consent Statement (Attachment 1) and:

O agree to participate.

OI prefer not to participate. 
Critical Thinking Training Survey - Contracting Faculty

\section{Demographic and Position Questions}

2. Are you a Professor of Contract Management at Defense Acquisition University?

OYes

ONo

\begin{tabular}{l|l|} 
Back & Next \\
\hline
\end{tabular}

Critical Thinking Training Survey - Contracting Faculty

3. Which region?

Capital and Northeast

Mid-Atlantic

South

Midwest

OWest

4. What is your gender?

OMale

OFemale

Back Next

Critical Thinking Training Survey - Contracting Faculty

5. How many years of contracting teaching experience do you have and how did you gain that experience? (Select one response per column.)

\begin{tabular}{c|c|c|}
$\begin{array}{c}\text { Years } \\
\text { teaching at } \\
\text { DAU }\end{array}$ & $\begin{array}{c}\text { Years teaching at } \\
\text { other DoD school }\end{array}$ & $\begin{array}{c}\text { Years teaching at } \\
\text { non-DoD institution }\end{array}$ \\
\hline
\end{tabular}

No

experience

Less than 3

years

3-5 years

6-10 years

$11-15$ years

$16-20$ years

Over 20

years

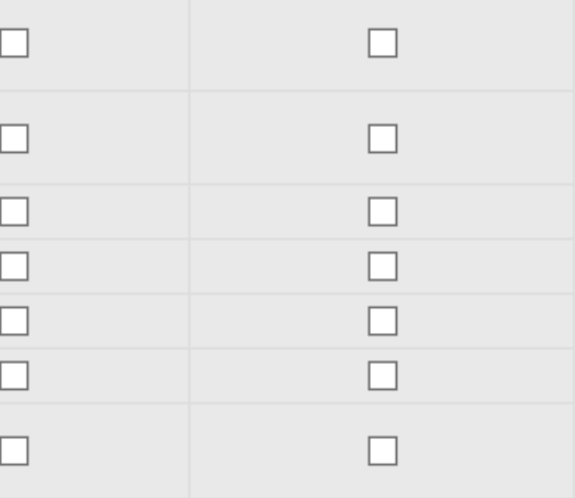

\begin{tabular}{|l|l|} 
Back & Next \\
\hline
\end{tabular} 
Critical Thinking Training Survey - Contracting Faculty

6. How many years of professional contracting experience (other than teaching) do you have and how did you gain that experience? (Select one response per column.)

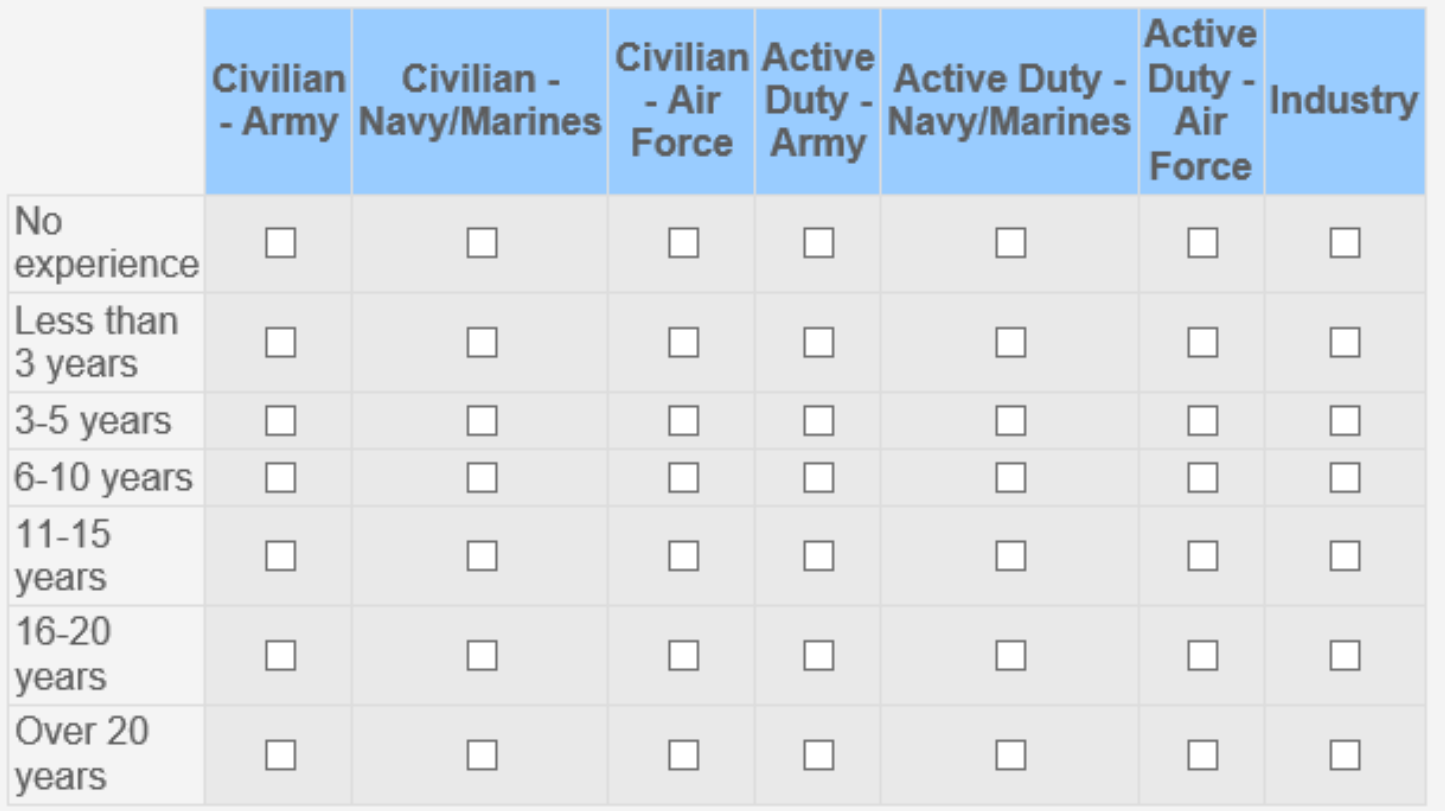

\begin{tabular}{l|l} 
Back & Next
\end{tabular}

Critical Thinking Training Survey - Contracting Faculty

\section{Survey Questions}

Many questions in this survey discuss DAU contracting courses. Course descriptions are included in Attachment 2 for your reference only. Please rank the courses based on your experience with a particular course and not the course description. These questions also address critical thinking skills that are defined in Attachment 3.

7. Please identify the mandatory Level I Contracting certification courses have you taught or taken in the last three years (in FYs 2013-2015) and rank the effectiveness of the critical thinking curriculum addressed in the course (on a scale where 1 = very ineffective and $7=$ very effective). If you have no recent experience with the course or the course didn't address critical thinking skills, mark "NA" as appropriate. (Select one response per row.)

\begin{tabular}{|c|c|c|c|c|c|c|c|c|c|}
\hline $\begin{array}{l}\text { Course } \\
\text { Number and } \\
\text { Name }\end{array}$ & $\begin{array}{c}\text { NA - no } \\
\text { recent } \\
\text { experience }\end{array}$ & $\begin{array}{l}\text { NA - } \\
\text { course } \\
\text { didn't } \\
\text { address } \\
\text { critical } \\
\text { thinking } \\
\text { skills }\end{array}$ & $\begin{array}{c}1 \text { - very } \\
\text { ineffective }\end{array}$ & $\stackrel{2-}{\text { ineffective }}$ & $\begin{array}{c}3- \\
\text { somewhat } \\
\text { ineffective }\end{array}$ & $\begin{array}{l}4 \text { - neither } \\
\text { effective } \\
\text { nor } \\
\text { ineffective }\end{array}$ & $\begin{array}{c}5 \text { - } \\
\text { somewhat } \\
\text { effective }\end{array}$ & $\begin{array}{c}6- \\
\text { effective }\end{array}$ & $\begin{array}{l}7 \text { - very } \\
\text { effective }\end{array}$ \\
\hline $\begin{array}{l}\text { CON 090- } \\
\text { Federal } \\
\text { Acquisition } \\
\text { Regulation } \\
\text { Fundamentals }\end{array}$ & 0 & 0 & 0 & 0 & 0 & 0 & 0 & 0 & 0 \\
\hline
\end{tabular}




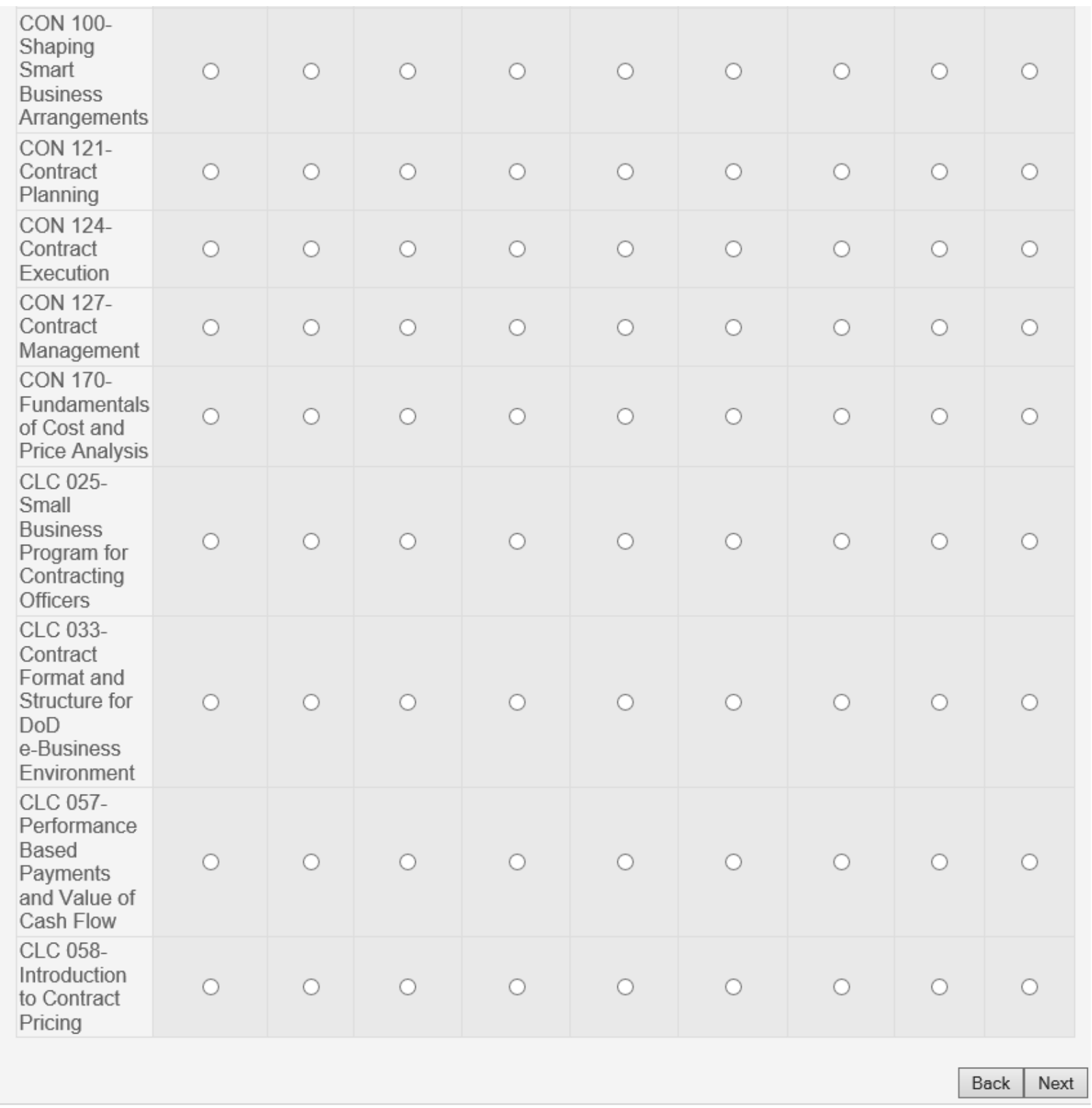


8. In your recent experience (last 3 years) with Level I DAU contracting courses that include critical thinking in the course curricula, please rank the extent you observed students exhibiting the listed critical thinking skills during the execution of classes.

Note: This response should indicate your general impression of students' application of critical thinking skills in the classes you either taught or took. Rankings are on a scale where $1=$ no critical thinking skills exhibited and $7=$ extensive critical thinking skills exhibited. If you have had no recent experience with Level I courses, please mark NA in the first column. (Select one response per row.)

\begin{tabular}{|c|c|c|c|c|c|c|c|c|}
\hline $\begin{array}{l}\text { Critical } \\
\text { Thinking } \\
\text { Skills } \\
\text { (Defined in } \\
\text { Attachment } \\
\text { 3) }\end{array}$ & $\begin{array}{l}0-\mathrm{NA} \text { - } \\
\text { No recent } \\
\text { experience } \\
\text { with Level } \\
\text { I courses }\end{array}$ & $\begin{array}{c}1- \\
\text { exhibited } \\
\text { no } \\
\text { critical } \\
\text { thinking } \\
\text { skills }\end{array}$ & $\begin{array}{l}2 \text { - } \\
\text { exhibited } \\
\text { few } \\
\text { critical } \\
\text { thinking } \\
\text { skills }\end{array}$ & $\begin{array}{c}3- \\
\text { exhibited } \\
\text { some } \\
\text { critical } \\
\text { thinking } \\
\text { skills }\end{array}$ & $\begin{array}{c}4- \\
\text { exhibited } \\
\text { average } \\
\text { critical } \\
\text { thinking } \\
\text { skills5 - } \\
\text { exhibited } \\
\text { above } \\
\text { average } \\
\text { critical } \\
\text { thinking } \\
\text { skills }\end{array}$ & $\begin{array}{c}5- \\
\text { exhibited } \\
\text { above } \\
\text { average } \\
\text { critical } \\
\text { thinking } \\
\text { skills }\end{array}$ & $\begin{array}{l}6 \text { - } \\
\text { exhibited } \\
\text { many } \\
\text { critical } \\
\text { thinking } \\
\text { skills }\end{array}$ & $\begin{array}{l}7- \\
\text { exhibited } \\
\text { extensive } \\
\text { critical } \\
\text { thinking } \\
\text { skills }\end{array}$ \\
\hline Interpretation & 0 & 0 & 0 & 0 & 0 & 0 & 0 & 0 \\
\hline Analysis & 0 & 0 & 0 & 0 & 0 & 0 & 0 & 0 \\
\hline Inference & 0 & 0 & 0 & 0 & 0 & 0 & 0 & 0 \\
\hline Evaluation & 0 & 0 & 0 & 0 & 0 & 0 & 0 & 0 \\
\hline Explanation & 0 & 0 & 0 & 0 & 0 & 0 & 0 & 0 \\
\hline $\begin{array}{l}\text { Self- } \\
\text { regulation }\end{array}$ & $\mathrm{O}$ & $\mathrm{O}$ & $\mathrm{O}$ & $\mathrm{O}$ & $\mathrm{O}$ & $\mathrm{O}$ & $\mathrm{O}$ & 0 \\
\hline
\end{tabular}


Critical Thinking Training Survey - Contracting Faculty

9. Please identify the mandatory Level II Contracting certification courses have you taught or taken in the last three years (in FYs 2013-2015) and rank the effectiveness of the critical thinking curriculum addressed in the course (on a scale where $1=$ very ineffective and $7=$ very effective). If you have no recent experience with the course or the course didn't address critical thinking skills, mark "NA" as appropriate. (Select one response per row.)

\begin{tabular}{|c|c|c|c|c|c|c|c|c|c|}
\hline $\begin{array}{l}\text { Course } \\
\text { Number and } \\
\text { Name }\end{array}$ & $\begin{array}{c}\text { NA - no } \\
\text { recent } \\
\text { experience }\end{array}$ & $\begin{array}{l}\text { NA - } \\
\text { course } \\
\text { didn't } \\
\text { address } \\
\text { critical } \\
\text { thinking } \\
\text { skills }\end{array}$ & $\begin{array}{c}1 \text { - very } \\
\text { ineffective }\end{array}$ & $\begin{array}{c}2- \\
\text { ineffective }\end{array}$ & $\begin{array}{c}3- \\
\text { somewhat } \\
\text { ineffective }\end{array}$ & $\begin{array}{l}4 \text { - neither } \\
\text { effective } \\
\text { nor } \\
\text { ineffective }\end{array}$ & $\begin{array}{c}5 \text { - } \\
\text { somewhat } \\
\text { effective }\end{array}$ & $\begin{array}{c}6- \\
\text { effective }\end{array}$ & $\begin{array}{l}7 \text { - very } \\
\text { effective }\end{array}$ \\
\hline
\end{tabular}

CON 200-

Business

Decisions for

Contracting

CON 216-

Legal

Considerations

in Contracting

CON $270-$

Intermediate

Cost and Price

Analysis

CON 280-

Source

Selection and

Administration

of Service

Contracts

CON 290

Contract

Administration

and

Negotiation

Techniques in

a Supply

Environment

CLC 051-

Managing

Government

Property in the

Possession of

Contractors

CLC 056-

Analyzing

Contract Costs

HBC 428-

Negotiating

\begin{tabular}{l|l|l|l}
0 \\
0
\end{tabular}

\begin{tabular}{|l|l|}
\hline \\
\hline
\end{tabular}

$\mathrm{O}$

O

0

O

O

0

O

O


10. In your recent experience (last 3 years) with Level II DAU contracting courses that include critical thinking in the course curricula, please rank the extent you observed students exhibiting the listed critical thinking skills during the execution of classes.

Note: This response should indicate your general impression of students' application of critical thinking skills in the classes you either taught or took. Rankings are on a scale where $1=$ no critical thinking skills exhibited and $7=$ extensive critical thinking skills exhibited. If you have had no recent experience with Level II courses, please mark NA in the first column. (Select one response per row.)

\begin{tabular}{|c|c|c|c|c|c|c|c|c|}
\hline $\begin{array}{l}\text { Critical } \\
\text { Thinking } \\
\text { Skills } \\
\text { (Defined in } \\
\text { Attachment } \\
\text { 3) }\end{array}$ & $\begin{array}{c}0 \text { - NA - } \\
\text { No recent } \\
\text { experience } \\
\text { with Level } \\
\text { Il courses }\end{array}$ & $\begin{array}{c}1- \\
\text { exhibited } \\
\text { no } \\
\text { critical } \\
\text { thinking } \\
\text { skills }\end{array}$ & $\begin{array}{c}2 \text { - } \\
\text { exhibited } \\
\text { few } \\
\text { critical } \\
\text { thinking } \\
\text { skills }\end{array}$ & $\begin{array}{l}3 \text { - } \\
\text { exhibited } \\
\text { some } \\
\text { critical } \\
\text { thinking } \\
\text { skills }\end{array}$ & $\begin{array}{l}4 \text { - } \\
\text { exhibited } \\
\text { average } \\
\text { critical } \\
\text { thinking } \\
\text { skills }\end{array}$ & $\begin{array}{c}5- \\
\text { exhibited } \\
\text { above } \\
\text { average } \\
\text { critical } \\
\text { thinking } \\
\text { skills }\end{array}$ & $\begin{array}{l}6- \\
\text { exhibited } \\
\text { many } \\
\text { critical } \\
\text { thinking } \\
\text { skills }\end{array}$ & $\begin{array}{l}7 \text { - } \\
\text { exhibited } \\
\text { extensive } \\
\text { critical } \\
\text { thinking } \\
\text { skills }\end{array}$ \\
\hline
\end{tabular}

\begin{tabular}{|l|l|l|l|l|l|l|l|l|}
\hline Interpretation & 0 & 0 & 0 & 0 & 0 & 0 & 0 & 0 \\
\hline Analysis & 0 & 0 & 0 & 0 & 0 & 0 & 0 & 0 \\
\hline Inference & 0 & 0 & 0 & 0 & 0 & 0 & 0 & 0 \\
\hline Evaluation & 0 & 0 & 0 & 0 & 0 & 0 & 0 & 0 \\
\hline Explanation & 0 & 0 & 0 & 0 & 0 & 0 & 0 & 0 \\
\hline $\begin{array}{l}\text { Self- } \\
\text { regulation }\end{array}$ & 0 & 0 & 0 & 0 & 0 & 0 & 0 & 0 \\
\hline
\end{tabular}


11. Please identify the mandatory Level III Contracting certification courses have you taught or taken in the last three years (in FYs 2013-2015) and rank the effectiveness of the critical thinking curriculum addressed in the course (on a scale where 1 = very ineffective and $7=$ very effective). If you have no recent experience with the course or the course didn't address critical thinking skills, mark "NA" as appropriate. (Select one response per row.)

\begin{tabular}{|c|c|c|c|c|c|c|c|c|c|}
\hline $\begin{array}{l}\text { Course } \\
\text { Number and } \\
\text { Name }\end{array}$ & $\begin{array}{c}\text { NA - no } \\
\text { recent } \\
\text { experience }\end{array}$ & $\begin{array}{l}\text { NA - } \\
\text { course } \\
\text { didn't } \\
\text { address } \\
\text { critical } \\
\text { thinking } \\
\text { skills }\end{array}$ & $\begin{array}{c}1 \text { - very } \\
\text { ineffective }\end{array}$ & $\begin{array}{c}2- \\
\text { ineffective }\end{array}$ & $\begin{array}{c}3- \\
\text { somewhat } \\
\text { ineffective }\end{array}$ & $\begin{array}{l}4 \text { - neither } \\
\text { effective } \\
\text { nor } \\
\text { ineffective }\end{array}$ & $\begin{array}{c}5 \text { - } \\
\text { somewhat } \\
\text { effective }\end{array}$ & $\begin{array}{c}6- \\
\text { effective }\end{array}$ & $\begin{array}{l}7 \text { - very } \\
\text { effective }\end{array}$ \\
\hline $\begin{array}{l}\text { CON 360- } \\
\text { Contracting } \\
\text { for Decision } \\
\text { Makers }\end{array}$ & 0 & 0 & 0 & 0 & 0 & 0 & 0 & 0 & 0 \\
\hline $\begin{array}{l}\text { Elective - } \\
\text { ACQ 265- } \\
\text { Mission- } \\
\text { Focused } \\
\text { Services } \\
\text { Acquisition }\end{array}$ & 0 & 0 & 0 & 0 & 0 & 0 & 0 & 0 & 0 \\
\hline $\begin{array}{l}\text { Elective - } \\
\text { ACQ 315- } \\
\text { Understanding } \\
\text { Industry } \\
\text { (Business } \\
\text { Acumen) }\end{array}$ & 0 & 0 & 0 & 0 & 0 & 0 & 0 & 0 & 0 \\
\hline $\begin{array}{l}\text { Elective - } \\
\text { ACQ 370- } \\
\text { Acquisition } \\
\text { Law }\end{array}$ & 0 & 0 & 0 & 0 & 0 & 0 & 0 & 0 & 0 \\
\hline $\begin{array}{l}\text { Elective - } \\
\text { CON 232- } \\
\text { Overhead } \\
\text { Management } \\
\text { of Defense } \\
\text { Contracts }\end{array}$ & 0 & 0 & 0 & 0 & 0 & 0 & 0 & 0 & 0 \\
\hline $\begin{array}{l}\text { Elective - } \\
\text { CON 244- } \\
\text { Construction } \\
\text { Contracting }\end{array}$ & 0 & 0 & 0 & 0 & 0 & 0 & 0 & 0 & 0 \\
\hline $\begin{array}{l}\text { Elective - } \\
\text { CON 252- } \\
\text { Fundamentals } \\
\text { of Cost } \\
\text { Accounting } \\
\text { Standards }\end{array}$ & 0 & 0 & 0 & 0 & 0 & 0 & 0 & 0 & 0 \\
\hline $\begin{array}{l}\text { Elective - } \\
\text { CON 334- } \\
\text { Advanced } \\
\text { Contingency } \\
\text { Contracting } \\
\text { Officer's } \\
\text { Course }\end{array}$ & 0 & 0 & 0 & 0 & 0 & 0 & 0 & 0 & 0 \\
\hline $\begin{array}{l}\text { Elective - } \\
\text { CON 370- } \\
\text { Advanced } \\
\text { Contract } \\
\text { Pricing }\end{array}$ & 0 & 0 & 0 & 0 & 0 & 0 & 0 & 0 & 0 \\
\hline
\end{tabular}


Critical Thinking Training Survey - Contracting Faculty

12. In your recent experience (last 3 years) with Level III DAU contracting courses that include critical thinking in the course curricula, please rank the extent you observed students exhibiting the listed critical thinking skills during the execution of classes.

Note: This response should indicate your general impression of students' application of critical thinking skills in the classes you either taught or took. Rankings are on a scale where $1=$ no critical thinking skills exhibited and $7=$ extensive critical thinking skills exhibited. If you have had no recent experience with Level III courses, please mark NA in the first column. (Select one response per row.)

\begin{tabular}{|c|c|c|c|c|c|c|c|c|}
\hline $\begin{array}{l}\text { Critical } \\
\text { Thinking } \\
\text { Skills } \\
\text { (Defined in } \\
\text { Attachment } \\
\text { 3) }\end{array}$ & $\begin{array}{c}0 \text { - NA - } \\
\text { No recent } \\
\text { experience } \\
\text { with Level } \\
\text { III courses }\end{array}$ & $\begin{array}{c}1- \\
\text { exhibited } \\
\text { no } \\
\text { critical } \\
\text { thinking } \\
\text { skills }\end{array}$ & $\begin{array}{l}2- \\
\text { exhibited } \\
\text { few } \\
\text { critical } \\
\text { thinking } \\
\text { skills }\end{array}$ & $\begin{array}{c}3- \\
\text { exhibited } \\
\text { some } \\
\text { critical } \\
\text { thinking } \\
\text { skills }\end{array}$ & $\begin{array}{l}4 \text { - } \\
\text { exhibited } \\
\text { average } \\
\text { critical } \\
\text { thinking } \\
\text { skills }\end{array}$ & $\begin{array}{c}5- \\
\text { exhibited } \\
\text { above } \\
\text { average } \\
\text { critical } \\
\text { thinking } \\
\text { skills }\end{array}$ & $\begin{array}{c}6 \text { - } \\
\text { exhibited } \\
\text { many } \\
\text { critical } \\
\text { thinking } \\
\text { skills }\end{array}$ & $\begin{array}{l}7 \text { - } \\
\text { exhibited } \\
\text { extensive } \\
\text { critical } \\
\text { thinking } \\
\text { skills }\end{array}$ \\
\hline Interpretation & 0 & 0 & 0 & 0 & 0 & 0 & 0 & 0 \\
\hline Analysis & 0 & 0 & 0 & 0 & 0 & 0 & 0 & 0 \\
\hline Inference & 0 & 0 & 0 & 0 & 0 & 0 & O & 0 \\
\hline Evaluation & 0 & 0 & 0 & 0 & 0 & 0 & 0 & 0 \\
\hline Explanation & 0 & 0 & 0 & 0 & 0 & 0 & 0 & 0 \\
\hline $\begin{array}{l}\text { Self- } \\
\text { regulation }\end{array}$ & 0 & $\mathrm{O}$ & $\mathrm{O}$ & 0 & 0 & $\mathrm{O}$ & $\mathrm{O}$ & 0 \\
\hline
\end{tabular}


Critical Thinking Training Survey - Contracting Faculty

13. In your general experience with DAU contracting courses, how effective are the following methods for teaching critical thinking skills? Rank the methods on a scale where $1=$ very ineffective and $7=$ very effective. If you have no experience with the method listed, mark "NA". (Select one response per row.)

\begin{tabular}{|c|c|c|c|c|c|c|c|c|}
\hline $\begin{array}{l}\text { Method of } \\
\text { teaching } \\
\text { critical } \\
\text { thinking } \\
\text { skills }\end{array}$ & $\begin{array}{l}\text { NA - No } \\
\text { experience } \\
\text { with this } \\
\text { method }\end{array}$ & $\begin{array}{c}1 \text { - very } \\
\text { ineffective }\end{array}$ & $\begin{array}{c}2- \\
\text { ineffective }\end{array}$ & $\begin{array}{c}3 \text { - } \\
\text { somewhat } \\
\text { ineffective }\end{array}$ & $\begin{array}{l}4 \text { - neither } \\
\text { effective } \\
\text { nor } \\
\text { ineffective }\end{array}$ & $\begin{array}{c}5 \text { - } \\
\text { somewhat } \\
\text { effective }\end{array}$ & $\begin{array}{c}6- \\
\text { effective }\end{array}$ & $\begin{array}{l}7 \text { - very } \\
\text { effective }\end{array}$ \\
\hline Case studies & 0 & 0 & 0 & 0 & 0 & 0 & 0 & 0 \\
\hline $\begin{array}{l}\text { Analysis of } \\
\text { scenarios }\end{array}$ & 0 & 0 & 0 & 0 & 0 & 0 & 0 & 0 \\
\hline Simulations & 0 & 0 & 0 & 0 & 0 & 0 & 0 & 0 \\
\hline Exercises & 0 & 0 & 0 & 0 & 0 & 0 & 0 & 0 \\
\hline $\begin{array}{l}\text { Creating } \\
\text { documents }\end{array}$ & 0 & 0 & 0 & 0 & 0 & 0 & 0 & 0 \\
\hline $\begin{array}{l}\text { Resolving } \\
\text { issues }\end{array}$ & 0 & 0 & 0 & 0 & 0 & 0 & 0 & 0 \\
\hline $\begin{array}{l}\text { Learning to } \\
\text { apply } \\
\text { quantitative } \\
\text { tools }\end{array}$ & 0 & 0 & 0 & 0 & 0 & 0 & 0 & 0 \\
\hline $\begin{array}{l}\text { Doing a critical } \\
\text { thiking project }\end{array}$ & 0 & 0 & 0 & 0 & 0 & 0 & 0 & 0 \\
\hline $\begin{array}{l}\text { Hands-on } \\
\text { analysis of } \\
\text { issues }\end{array}$ & 0 & $\mathrm{O}$ & 0 & 0 & 0 & $\mathrm{O}$ & 0 & 0 \\
\hline $\begin{array}{l}\text { Interpretation } \\
\text { of } \\
\text { policy/issues }\end{array}$ & 0 & 0 & 0 & 0 & 0 & 0 & 0 & 0 \\
\hline $\begin{array}{l}\text { Other (please } \\
\text { list below) }\end{array}$ & O & 0 & 0 & 0 & 0 & 0 & 0 & 0 \\
\hline
\end{tabular}

list below)
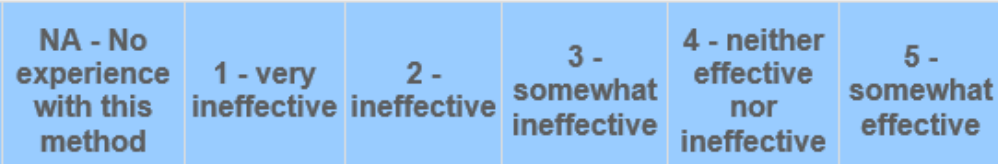

ctive 
15. Have the following DAU contracting courses had a major critical thinking related revision(s) since the implementation of Better Buying Power (BBP) initiatives? (Select one "no" response or multiple "yes" responses as applicable for each row.)

\begin{tabular}{|c|c|c|c|c|c|}
\hline $\begin{array}{l}\text { Course number } \\
\text { and name }\end{array}$ & $\begin{array}{c}\text { No } \\
\text { experience } \\
\text { with this } \\
\text { course }\end{array}$ & $\begin{array}{c}\text { No } \\
\text { revisions } \\
\text { that I } \\
\text { know of }\end{array}$ & $\begin{array}{c}\text { Yes - } \\
\text { Revised } \\
\text { after } \\
\text { BBP 1.0 } \\
\text { (Jun } \\
\text { 2010) }\end{array}$ & $\begin{array}{c}\text { Yes - } \\
\text { Revised } \\
\text { after } \\
\text { BBP 2.0 } \\
\text { (Nov } \\
\text { 2012) }\end{array}$ & $\begin{array}{c}\text { Yes - } \\
\text { Revised } \\
\text { after } \\
\text { BBP } 3.0 \\
\text { (Apr } \\
\text { 2015) }\end{array}$ \\
\hline
\end{tabular}

\section{LEVEL I}

\section{COURSES}

CON 090-Federal

Acquisition

Regulation

Fundamentals

CON 100-

Shaping Smart

Business

Arrangements

CON 121-

Contract Planning

CON 124-

Contract

Execution

CON 127-

Contract

Management

CON 170-

Fundamentals of Cost and Price

Analysis

CLC 025-Small

Business

Program for

Contracting

Officers

CLC 033-

Contract Format and Structure for DoD e-Business Environment 


\begin{tabular}{l} 
CLC 057- \\
Performance \\
Based Payments \\
and Value of \\
Cash Flow \\
CLC 058- \\
Introduction to \\
Contract Pricing \\
LEVEL II \\
COURSES \\
CON 200- \\
Business \\
Decisions for \\
Contracting \\
CON 216- Legal \\
Considerations in \\
Contracting \\
CON 270- \\
Intermediate Cost \\
and Price \\
Analysis \\
CON 280-Source \\
Selection and \\
Administration of \\
Service Contracts \\
CON 290- \\
Contract \\
Administration \\
and Negotiation \\
Techniques in a \\
Supply \\
Environment \\
CLC 051- \\
Managing \\
Government \\
Property in the \\
Possession of \\
Contractors \\
CLC 056- \\
Analyzing \\
Contract Costs \\
HBS 428- \\
Negotiating \\
LEVEL III \\
cOURSES \\
\hline
\end{tabular}




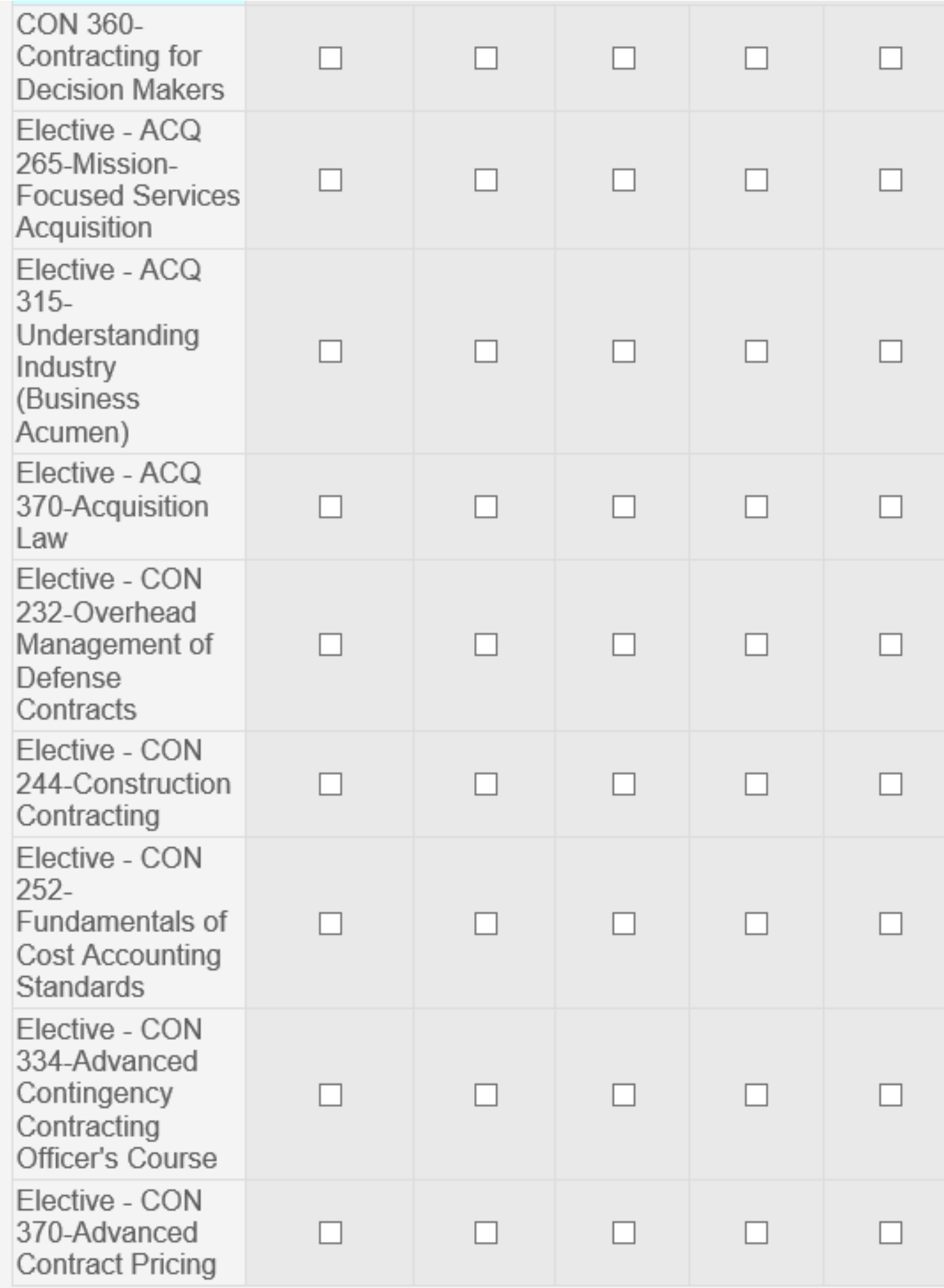


Critical Thinking Training Survey - Contracting Faculty

16. As the result of the major critical thinking related revision(s) to the courses listed in the previous question, have you generally observed an improvement in the critical thinking skills of the contracting workforce students in your classes? (Select one response and add associated comments, as appropriate.)

OYes

No

Not Sure

17. Based on your experience with DAU contracting courses, would you suggest any improvements or additions to the mandatory contracting course curriculum to improve critical thinking skills? (Select one response and add associated comments, as appropriate.)

OYes

ONo

Not Sure

18. Do you think a course (with a format similar to PMT 401 - case-based scenarios and simulations) would be a useful addition to the contracting course curriculum to improve critical thinking skills? (Select one response and add associated comments, as appropriate.)

OYes - it should be a mandatory course

YYes - it should be an elective course

ONo

ONot sure

19. Are there any topics related to training the contracting workforce in critical thinking skills that you think require further research? (Select one response and add associated comments, as appropriate.)

OYes

ONo 


\section{Appendix E - Survey Attachments}

\section{Informed Consent Statement}

\section{Informed Consent Statement Senior Service College Fellowship (SSCF) Research}

As an adult 18 years of age or older, I agree to participate in this research about Critical Thinking Training in the Army Contracting Workforce. This survey is being conducted to support research efforts being performed by Cheryl Jones, a student of the Senior Service College Fellowship Program of the Defense Acquisition University. I understand that my participation is entirely voluntary; I can withdraw my consent at any time. By agreeing to participate in this study, I indicate that I understand the following:

1. The purpose of this research is to determine if contracting professionals have been trained to develop their critical thinking skills to assist them in making sound business decisions and implement Better Buying Power initiatives and to determine if there is need for additional, different, or earlier training. Should I choose to participate in the survey, I am aware that my feedback will be consolidated with other feedback associated with this research effort. In addition to a research paper to support the graduation requirements from the SSCF, research findings may be shared more broadly through briefings, publications, and conferences.

2. If I choose to participate in this research, I will be asked to complete an online questionnaire. The survey asks questions on your demographic information, your experience with critical thinking training, and your opinions on critical thinking in the contracting curriculum.

3. There is no incentive for participation.

4. All items in the questionnaire are important for analysis and my data input will be more meaningful if all questions are answered. However, I do not have to answer any that I prefer not to answer. I can discontinue my participation at any time without penalty by exiting out of the survey.

5. This research will not expose me to any discomfort or stress beyond that which might normally occur during a typical day. There are no right or wrong answers; thus, I need not be stressed about finding a correct answer.

6. There are no known risks associated with my participating in this study.

7. Data collected will be handled in a confidential manner. The data collected will remain anonymous.

8. The purpose of this research has been explained and my participation is entirely voluntary.

9. I understand that the research entails no known risks and by completing this survey, I am agreeing to participate in this research.

The Defense Acquisition University, South Region, carries out Senior Service College Fellowship research under the oversight of assigned faculty research advisors and the Director of the Senior Service College Fellowship, South Region. Questions or problems regarding these activities should be addressed to Mr. John Daniels, Director, SSCF South Region, at John.Daniels@dau.mil, 7115 Old Madison Pike, Huntsville, AL, 35806, 256-922-8055.

Reference: DoDl 3216.02, Protection of Human Subjects and Adherence to Ethical Standards in DoDSupported Research, 8 November 2011

\section{Contracting Certification Course Descriptions - see Appendix B}




\section{Critical Thinking Definitions and Skills}

\section{Critical Thinking Definition and Skills}

\section{Critical Thinking}

This survey asks several questions about critical thinking concepts. To introduce common reference points for survey participants, the following statements (developed by a panel of critical thinking experts) is provided to define critical thinking:
We understand critical thinking to be purposeful, self-regulatory judgement which results in interpretation, analysis, evaluation, and inference, as well as explanation of the evidential, conceptual, methodological, criteriological, or contextual considerations upon which that judgement is based.... The ideal critical thinker is habitually inquisitive, well-informed, trustful of reason, open-minded, flexible, fair-minded in evaluation, honest in facing personal biases, prudent in making judgements, willing to reconsider, clear about issues, orderly in complex matters, diligent in seeking relevant information, reasonable in the selection of criteria, focused on inquiry, and persistent in seeking results which are as precise as the subject and the circumstances of inquiry permit.

Reference: Facione, P.A. (1990) Critical Thinking: A Statement of Expert Consensus for Purposes of Educational Assessment and Instruction, Executive Summary ("The Delphi Report"), p. 2.

\section{Kritical Thinking Skills}

Explanations of core critical thinking skills are also provided for common reference points for survey participants:

Interpretation - "To comprehend and express the meaning or significance of a wide variety of experiences, situations, data, events, judgements, conventions, beliefs, rules, procedures, or criteria ${ }^{n}$

Analysis - "To identify the intended and actual inferential relationships among statements, questions, concepts, descriptions, or other forms of representation intended to express belief, judgment, experiences, reasons, information, or opinions"

Inference - "To identify and secure elements needed to draw reasonable conclusions; to form conjectures and hypothesis; to consider relevant information and to reduce the consequences flowing from data, statements, principles, evidence, judgments, beliefs, opinions, concepts, descriptions, questions, or other forms of representation"

Evaluation - "To assess the credibility of statements or other representations that are accounts or descriptions of a person's perception, experience, situation, judgment, belief, or opinion; and to assess the logical strength of the actual or intended inferential relationships among statements, descriptions, questions, or other forms of representation"

Explanation - "To state and to justify that reasoning in terms of the evidential, conceptual, methodological, criteriological, and contextual considerations upon which one's results were based; and to present one's reasoning in the form of cogent arguments"

Self-regulation - "Self-consciously to monitor one's cognitive activities, the elements used in those activities, and the results educed, particularly by applying skills in analysis, and evaluation to one's own inferential judgments with a view toward questioning, confirming, validating, or correcting either one's reasoning or one's results"

Reference: Facione, P.A. (2015) " $C$ Critical Thinking: What It is and Why It Counts", Measured Reasons LLC, Hermosa Beach, CA, pp. 9 - 10 


\section{Appendix F - Survey Demographics}

\section{Contracting Workforce Survey Demographics}

Current status. Figure 36 illustrates the status of the 190 survey respondents. Seventy-six percent of survey participants (or 145 respondents) in the sample population identified themselves as a DA civilian employee in an 1102 series position. Twenty-one percent of survey participants (or 39 respondents) selected active duty Army members in 51C or 51Z MOS codes. Three percent (or 6 respondents) indicated they were Local National (LN) employees employed in a C-1102 contracting position. The survey data does not include those respondents that selected that none of these categories reflected their current status, since the survey was programmed to end at this point for these respondents.

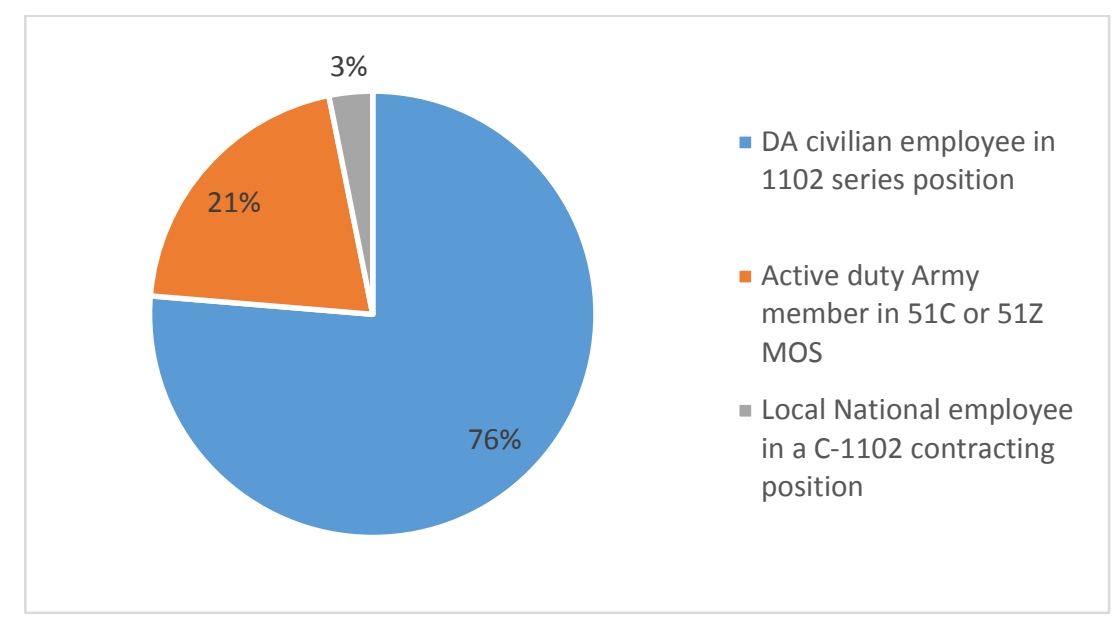

Figure 36. Respondent status (workforce) (Jones, 2016b).

Rank or paygrade. Figure 37 illustrates the percentage of respondents in each of the DA civilian or LN paygrades or military ranks. The sample (at 76\% DAC, 21\% Military, and $3 \% \mathrm{LN}$ ) is largely representative of the ACC contracting population estimated by G1 (personal communication, 17 December 2015): 80.3\% DAC, 17.2\% Military, and 2.5\% LN. 


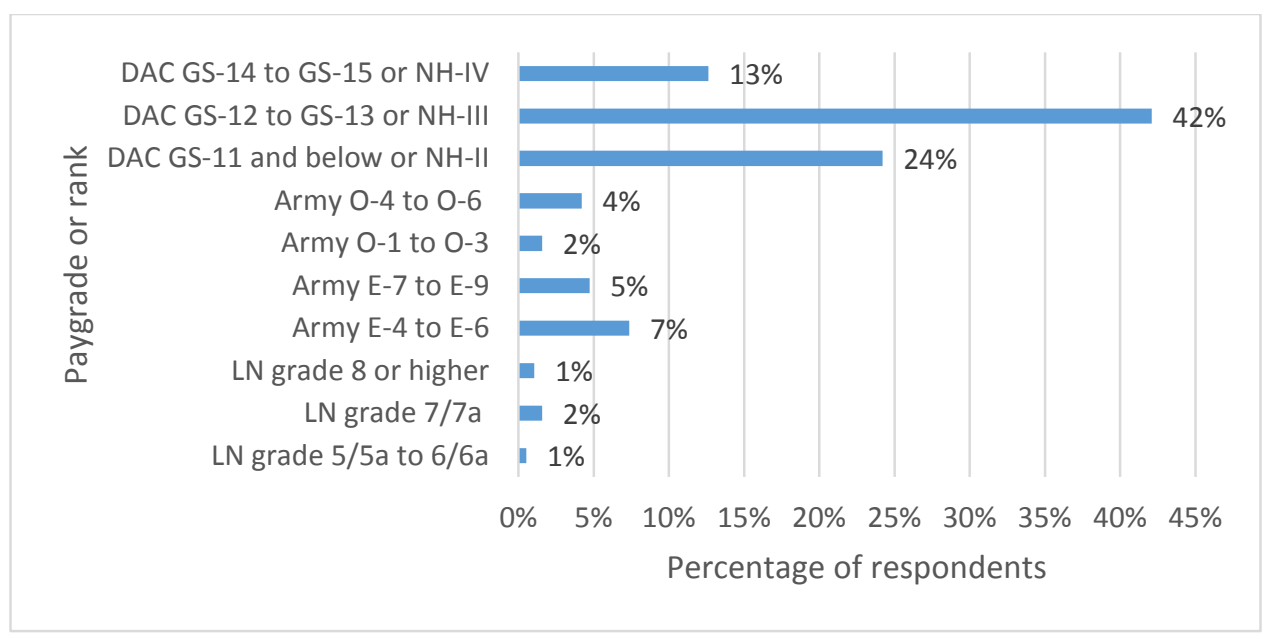

Figure 37. Respondent rank or paygrade (workforce) (Jones, 2016b).

Generation and gender. Figure 38 gives the generational breakdown of workforce survey respondents and the corresponding birth years for each generation. Survey data in Figure 39 provides the gender breakdown of survey respondents.

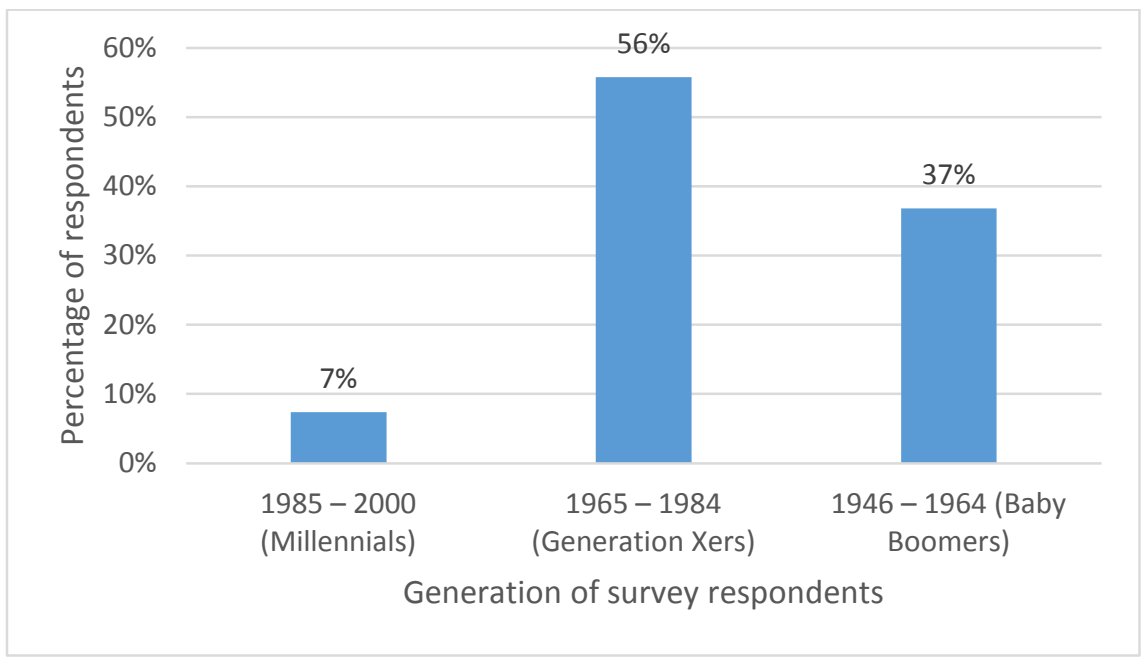

Figure 38. Generational breakdown (workforce) (Jones, 2016b). 


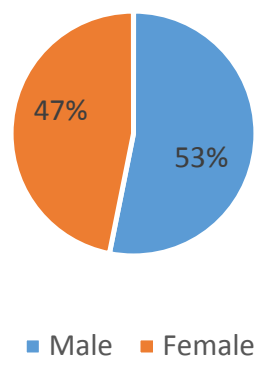

Figure 39. Gender breakdown (workforce) (Jones, 2016b).

Contracting experience. The years of contracting experience and the manner that experience was gained for workforce survey respondents is represented in Figure 40. The concentration of contracting experience (whether it was civilian, military, or private industry experience) is on the left third of the graph and indicates the relatively low experience level of the contracting workforce.

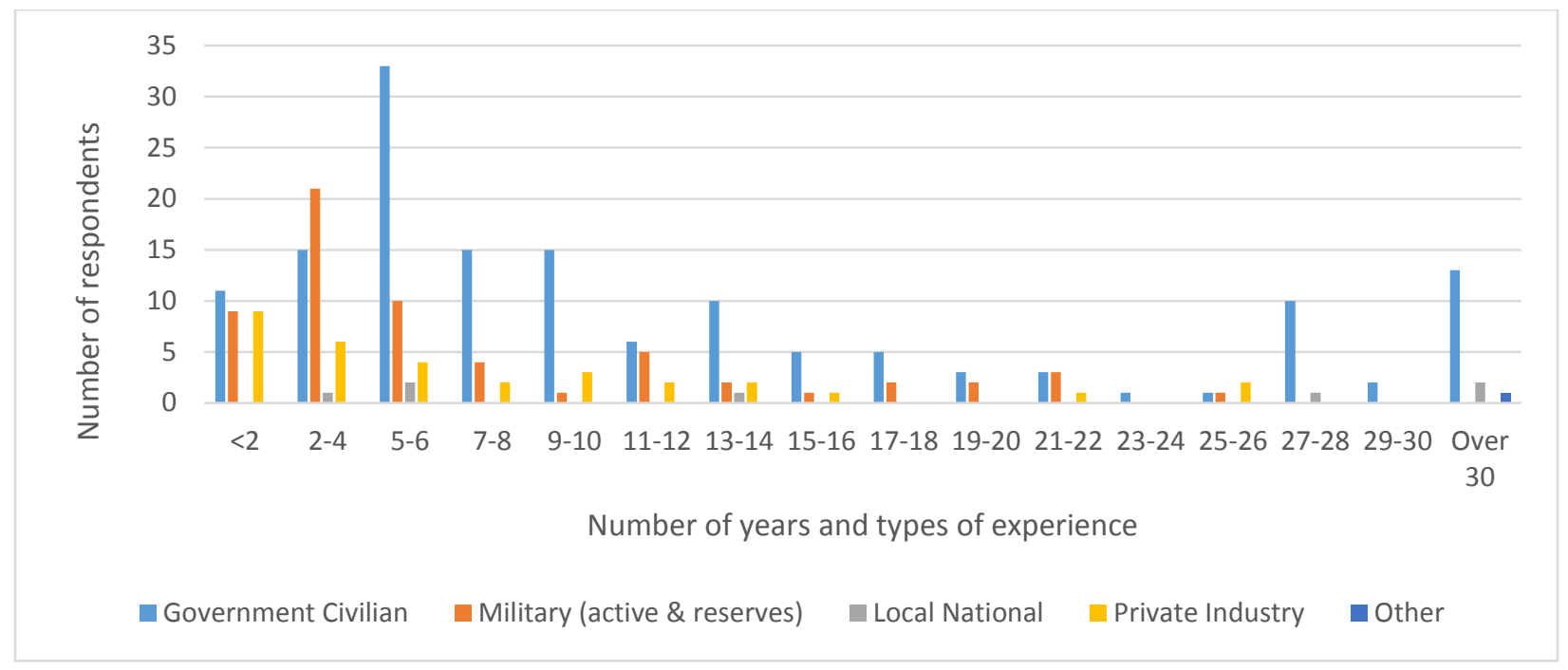

Figure 40. Contracting experience (workforce) (Jones, 2016b).

Contracting certification levels. Figure 41 indicates the number of respondents certified in each level of the contracting career field and the timeframe of certification at each level. As in the previous figure, the certification timeframe of the ACC workforce is 
concentrated in the left third of Figure 41, indicating the workforce's certification is relatively recent.

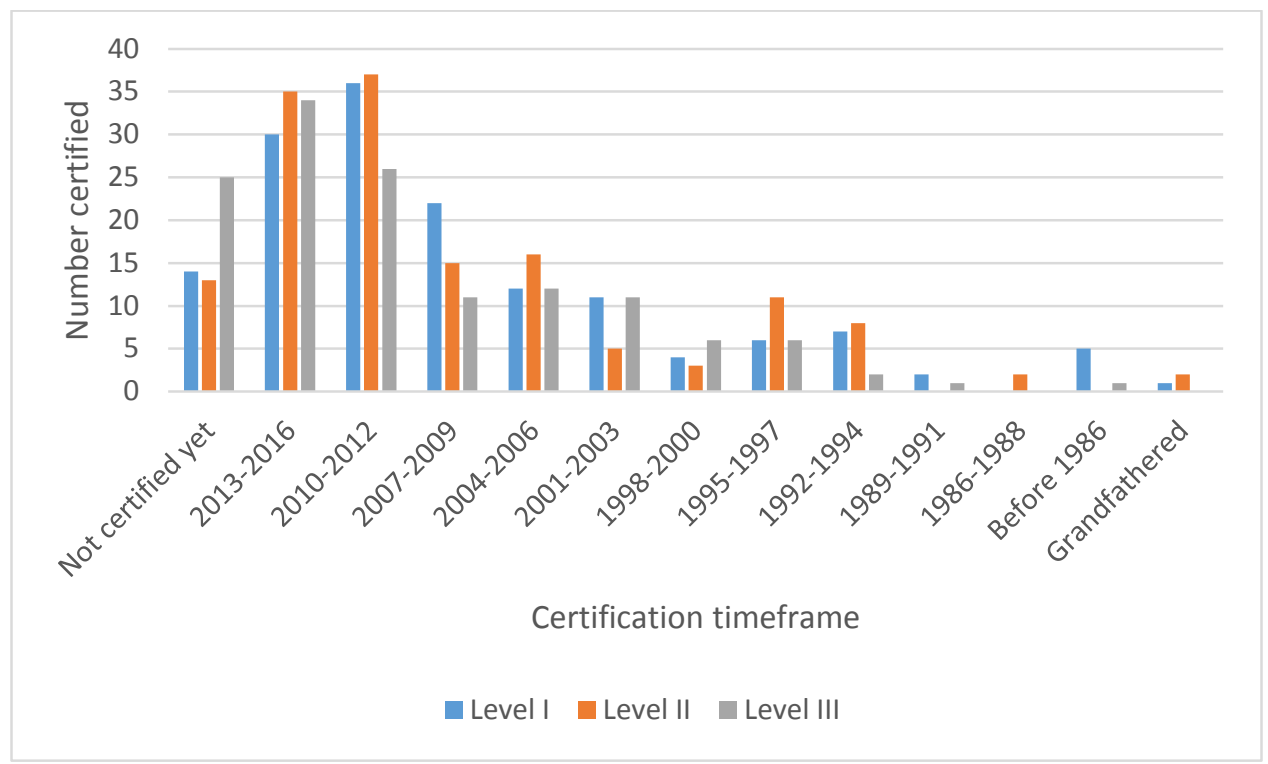

Figure 41. Contracting certification levels (workforce) (Jones, 2016b.)

Education level. The highest education level obtained by workforce survey respondents is indicated in Figure 42.

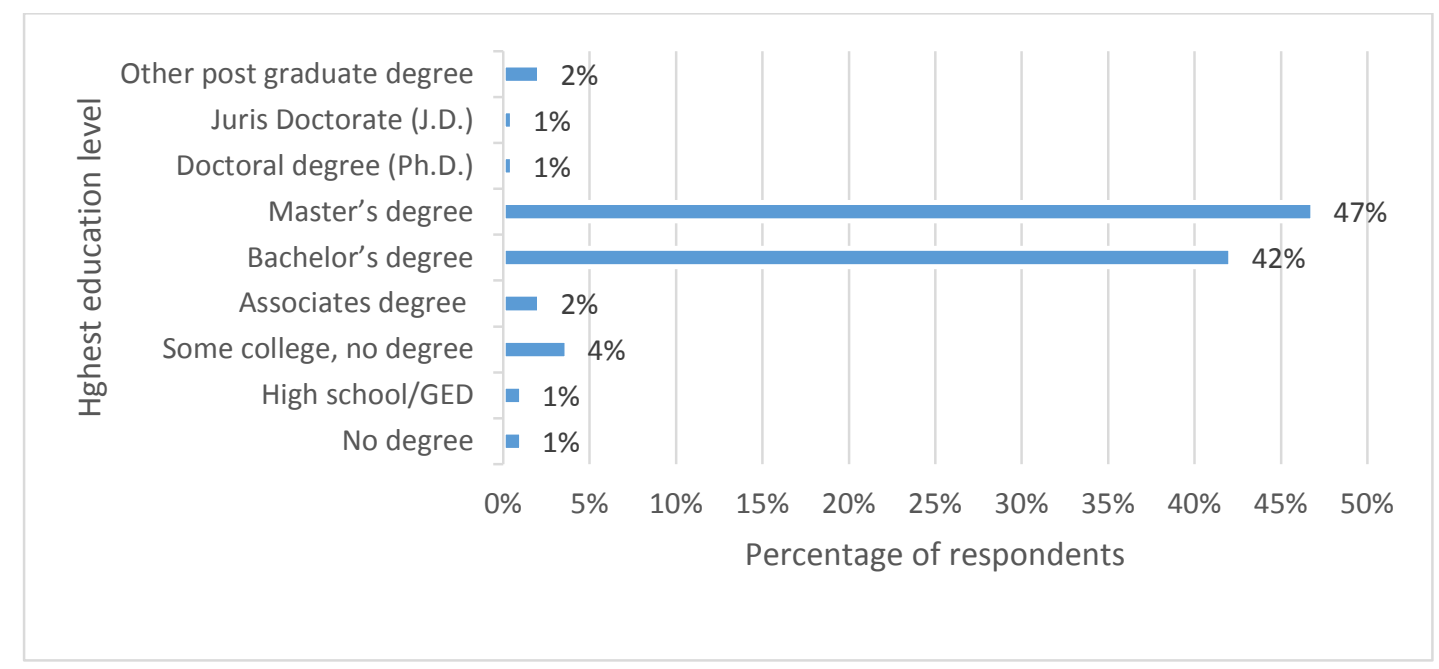

Figure 42. Education levels (workforce) (Jones, 2016b).

Due to DAWIA educational requirements for contracting certification, contracting professionals are required to have at least a Bachelor's degree (or be grandfathered into their position if in the 
career field prior to DAWIA). Ninety-two percent of the respondents have a Bachelor's degree or higher.

Command representation. Figure 43 indicates the respondents’ ACC employing command. The data indicates some participation from almost all ACC commands in the response to the workforce survey. Forty three percent of respondents worked for the MICC, 37\% worked for a Contracting Center, $16 \%$ worked for ECC, and $4 \%$ worked for HQ ACC.

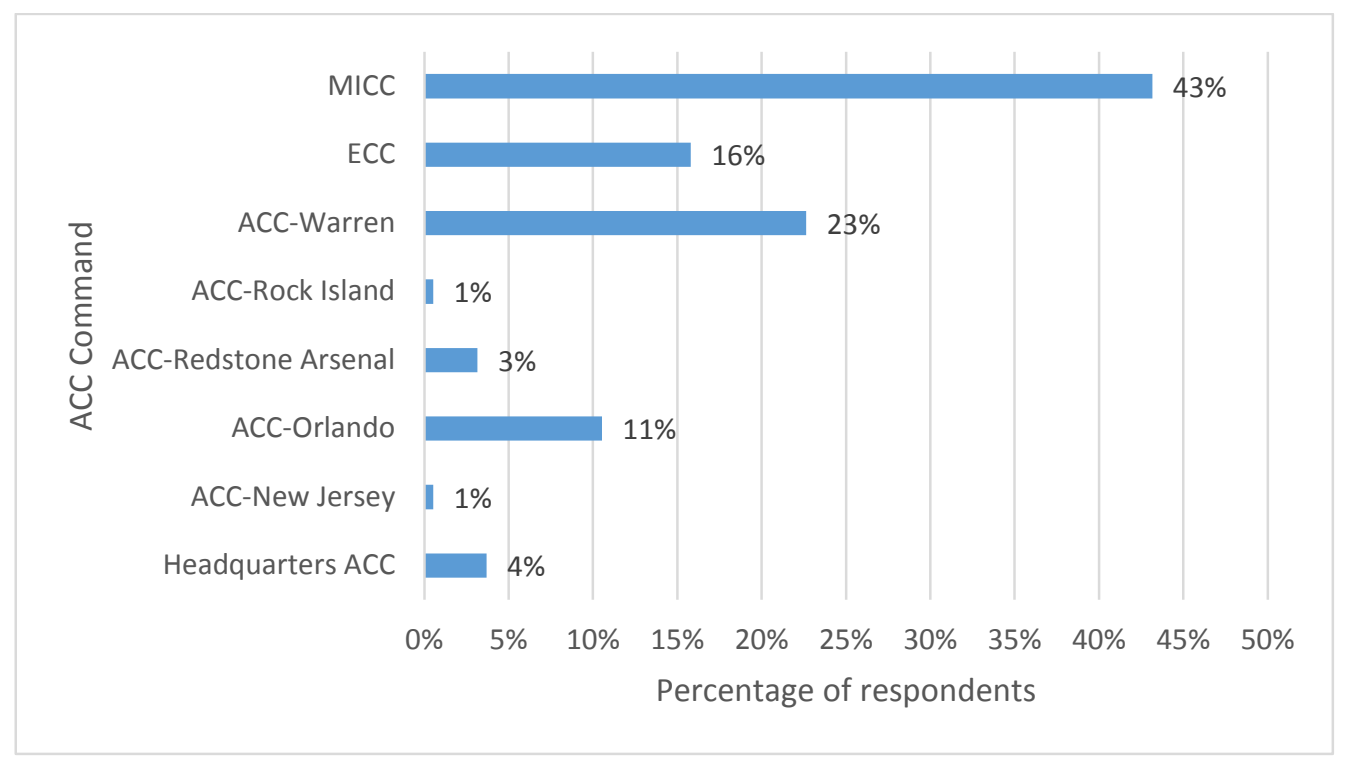

Figure 43. ACC command representation (workforce) (Jones, 2016b).

\section{DAU Contracting Faculty Survey Demographics}

Region and gender. Figure 44 provides a breakdown of the percentage of the 22 faculty respondents by DAU region. Figure 45 indicates the gender of the survey respondents. 


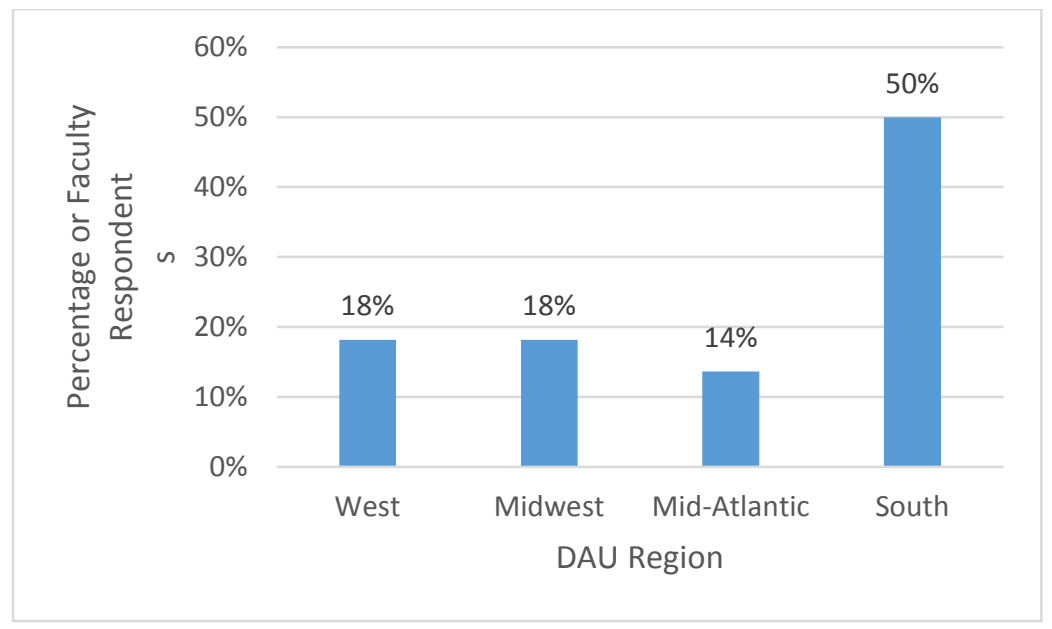

Figure 44. Survey participation by DAU region (faculty) (Jones, 2016a).

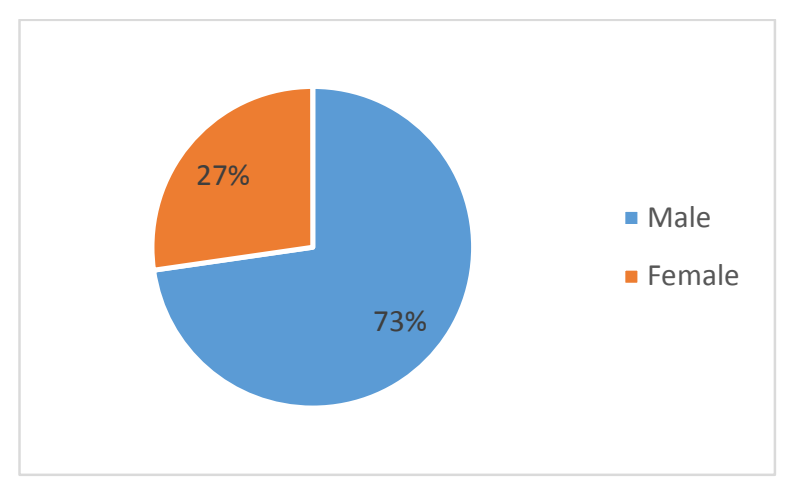

Figure 45. Gender of survey participants (faculty) (Jones, 2016a).

Teaching experience and manner experience was gained. A question on the DAU contracting faculty survey requested information on the number of years of contracting teaching experience faculty had and how faculty members obtained that experience- teaching at DAU, at another DoD school, or in a non-DoD school. Figure 46 illustrates the breakdown of contracting teaching experience. Approximately two thirds of the contracting faculty have taught at DAU 
for at least six years. Just under half of the faculty responding to the survey have experience teaching contracting outside of DAU.

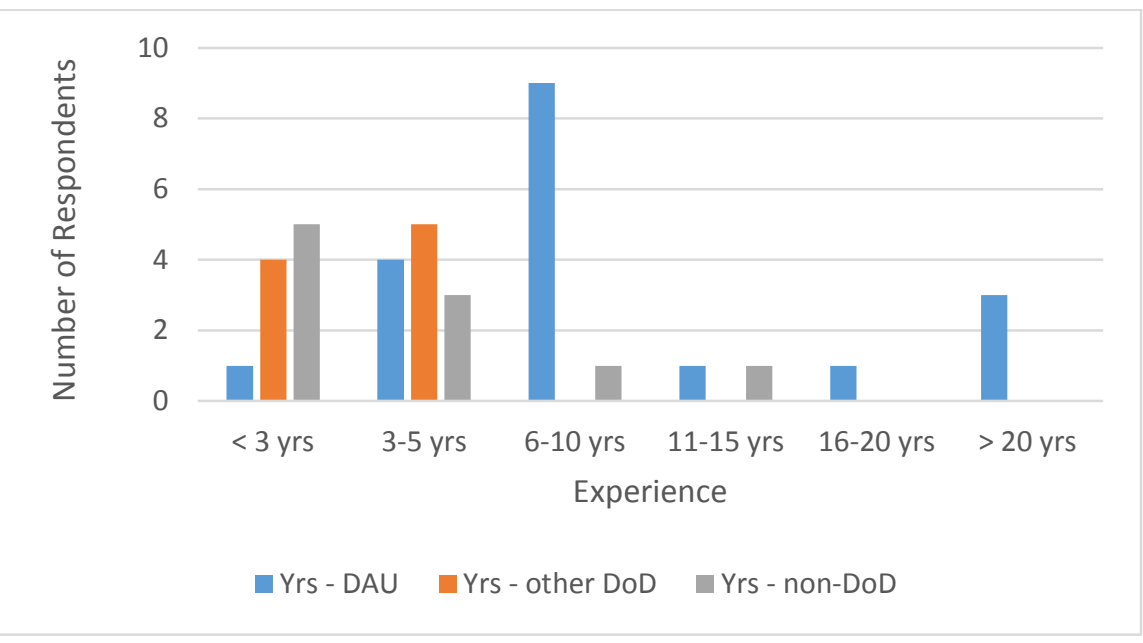

Figure 46. Teaching experience and how gained (faculty) (Jones, 2016a).

Contracting experience and manner experience was gained. DAU faculty members responding to a question regarding how many years of professional contracting experience (other than in teaching) they had and how they obtained that contracting experience. The number of faculty with civilian or active duty experience (with the Army, Navy or Marine Corps, or Air Force) or with private industry experience are illustrated in Figure 47.

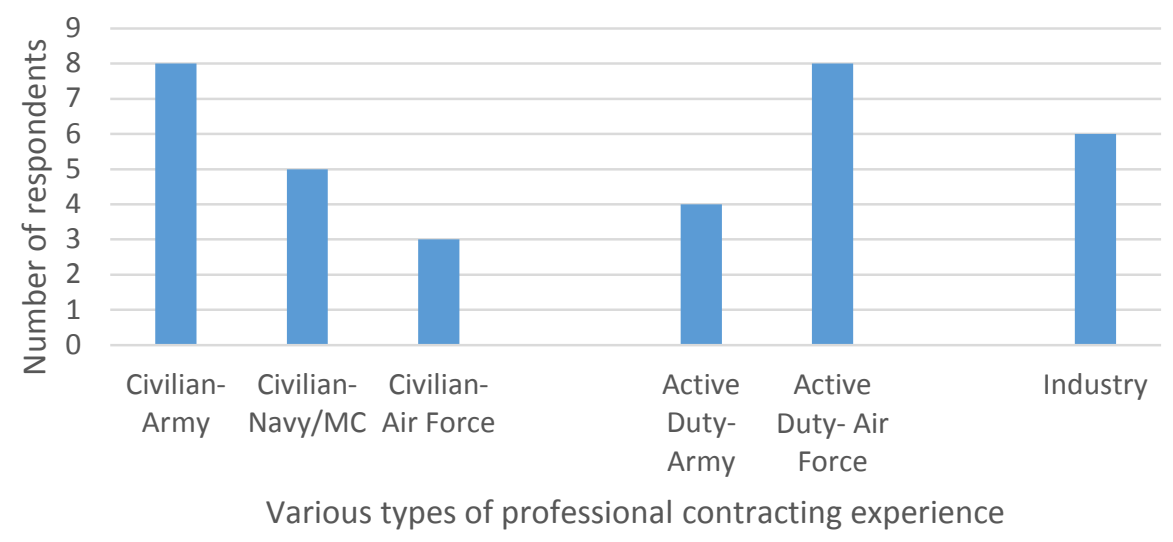

Figure 47. Professional experience and how gained (faculty) (Jones, 2016a). 